\title{
Re-crear el cristianismo: la actualidad de Jesús frente a la religiosidad postmoderna del segundo nihilismo y del neopaganismo
}

\section{Propuestas del Reino de Dios, propuestas desacralizadoras}

\author{
JeSÚS de NAZARET, INTÉRPRETE ÚNICO dE DIOS Y LA RELIGIÓN \\ NUEVA PROPUESTA CRISTOLÓGICA DENTRO DE LA RELIGIOSIDAD DEL \\ DIOS-MISTERIO COMÚN, EL RETORNO DE LA NUEVA MITOLOGÍA \\ Y EL NIHILISMO CONTEMPORÁNEOS
}

\section{INTRODUCCIÓN}

Reflexionando desde el año 2008, me doy cuenta de que la experiencia cristiana es muy distinta de hace 20 años o de cómo pensaba que se vivía. No sólo la caída de creyentes practicantes, sino también el sincretismo, que tanto tributo rinde al neopaganismo, que se vive dentro del cristianismo me han hecho reflexionar sobre el porqué de esta nueva forma de experiencia religiosa cristiana, aparte del fenómeno sincrónico de pérdida de cantidad y, sobre todo y más alarmante, del naufragio de la identidad más netamente cristiana (si es que alguna vez ha existido en la experiencia de la Iglesia universal).

Por otra parte, mi siempre cercanía a los jóvenes-adolescentes me ha hecho tanto respirar este cristianismo diverso (o también un tipo de religiosidad que nada tiene que ver) como suscitar esta reflexión que me propongo hacer.

Mi exposición, por tanto, versará sobre la experiencia religiosa, y religiosa cristiana, en España (aunque se podría generalizar para toda la Europa occidental) con especial atención a los rasgos que transmiten los jóvenes. Antes de sintetizar esquemáticamente y ofrecer las claves de lectura de mi propuesta, debo clarificar con honestidad que mi planteamiento parte de una cristología ascendente (desde abajo, sobre todo la que toma completamente en serio la encarnación hasta sus últimas consecuencias como Schillebeeckx o Duquoc), con especial atención a sus vertientes de la 
secularización (comenzada por Gogarten), la ausencia de Dios (con un eje fundamental en Bonhoeffer) y la política (valga Metz como piedra angular). Todo ello, basado en la recuperación de la plenitud del centro de la Revelación, quien hizo presente (y subrayo el hecho de presencializar en oposición al de anunciar) el acontecimiento liberador del Reino de Dios. Una realidad que sólo puede llevarse a cabo in-corporándose, a través de la experiencia humano sensorial (vertiente de Salmann, De Santis, Gaburro) y a través del encuentro interpersonal (ni más ni menos que la centralidad del lenguaje bíblico: una antropología relacional que se lleva a plenitud en todo encuentro personalizante-liberador, que precede a toda expresión cultual; buen ejemplo serían las reflexiones de Buber, Lévinas, Rosenzweig o Marion). Desde esta orientación se me hace inevitable concluir una exposición cristológica que no ahonde sus raíces en una profundización de la Revelación en su perspectiva encarnacionista, histórica, existencial, personalista, donde, insisto, la clave será tener como fundamento y horizonte, no sólo un diálogo con las urgencias pastorales actuales (auditus temporis et alterius) como si tratásemos de un producto comercial, sino el lenguaje y propuesta del centro de la Revelación: el proyecto del Reino de Dios.

Los dos capítulos de que consta mi trabajo se dividen en una parte de análisis de la realidad, del tipo de experiencia religiosa que se vive, para después, en un segundo momento proponer una oferta diversa para vivir la experiencia cristiana con otro tipo de perspectiva. Precisamente, porque entiendo que uno de los grandes límites a la hora de buscar o proponer soluciones es el desconocimiento del hecho humano-religioso en sí, es decir, analizando tal y como se vive de hecho, parto de este análisis de la realidad, de la experiencia humano-religiosa, para perfilar bien quién es el destinatario de nuestra propuesta o, simplemente, cuál es el rostro ante el cual tenemos que hacer visible la credibilidad de la Revelación (unas cuantas dosis de fenomenología, tampoco irían mal al cristianismo, precisamente para encarnarse debidamente).

El primer capítulo, por tanto se ocupará de analizar los dos fenómenos determinantes, según mi opinión, que configuran la experiencia humanoreligiosa de los jóvenes españoles de hoy día. En un primer momento analizaré el fenómeno del neopaganismo o religiosidad mítica. Una religiosidad basada en la eclosión de la Vida, en la centralidad de la divinidad dionisíaca que permite desencadenar toda la potencialidad de la vida, con un mecanismo de autosatisfacción, confort y justificación de la persona y del sistema social, sin capacidad denunciante, integradora y personalizante; en definitiva, una experiencia que reacciona contra los grandes relatos que han fra- 
casado como medios de la emancipación de la persona, comenzando por el cristianismo. La segunda parte del primer capítulo, continuará exponiendo el fenómeno del nihilismo en su retorno. Precisamente, por el fracaso de los grandes relatos, de la racionalidad absolutizada, de la religión alienante, cuando no fanática, no puede llegar sino el desencanto ante un mundo que no se puede controlar ${ }^{1}$. La razón no puede más que intuir pequeños destellos de la realidad y nuestra condición hermenéutica sólo nos dice que la vida, como fragmentada, simplemente se puede vivir de acuerdo a pequeños, fugaces y mutables intuiciones-fundamentos. No hay ni grandes ideologías ni tampoco un más allá en el que confiar; la salvación más allá de la muerte ha mostrado la fragilidad de la vida y la inconsistencia de tal argumentación, porque en este siglo pasado sólo hemos visto visos de destrucción. Por tanto, ante un desencanto frente a todo tipo de racionalidad y religión contundente o planteamiento metafísico, sólo puede surgir la experiencia nihilista-neopagana. Es lógico que ante la debilidad de las grandes argumentaciones, emerja un tipo de religiosidad cómoda, que sirva a la persona, que le desvele que dentro de los límites de su existencia puede desarrollar todas sus potencialidades, hacer eclosionar la Vida en la fusión holística con la naturaleza, con el cosmos. El mito junto con el nihilismo, llevan a una especie de hedonismo que, por una parte, enseña a la persona a reaccionar contra el peso de la vida cotidiana, contra los problemas a los que la metafísica y la religión habían respondido de forma tajante y segura, pero, por otra ofrece una propuesta desprovista de fundamento.

En el segundo capítulo parto todavía del análisis, en este caso, del cristianismo. Al final del primer capítulo se puede afirmar que, ante el fracaso de las grandes respuestas, esta religiosidad neopagana-nihilista no sólo surge, sino que ha explotado creciendo inmensamente. Por tanto este capítulo, considerando el crecimiento de la sensibilidad religiosa, intenta partir de una explicación del porqué el cristianismo como sistema religioso decae. La respuesta es que el cristianismo, sin ser consciente, ha perdido su identidad, precisamente, contaminándose de los mecanismos de este tipo de religiosidad neopagana: un cristianismo que permanece al nivel de un ritualismo que se concentra más en la lógica del confort, del individualismo, del

1 Cf. MARDONES, J.M., "Nuevos contextos de evangelización" en Vv.AA., Evangelizar, ésa es la cuestión, PPC, Madrid 2006, 43-46, donde el autor plantea la sociedad de la incertidumbre y el riesgo como consecuencia de una razón débil y fragmentada y de un mundo manipulado por la técnica, cuyas repercusiones fisiológicas y morales son imposibles de controlar. Ante ello, por desgracia, surge la religión, también la cristiana, como reacción "miedosa y búsqueda de seguridad". 
intervencionismo, de la justificación de mi existencia y, cuando se analiza un cristianismo más práctico (voluntariado, peregrinaciones, procesiones) se constata que goza de la misma fugacidad, porque no hay una opción fundamental por el "encuentro liberador" con la presencia de la Revelación hoy. Por un lado, la vivencia de ese desencanto de la vida y la necesidad de hacer emerger las dimensiones de la persona que han sido encarceladas por las grandes ideologías hacen que los cristianos necesiten de este tipo de religiosidad y, por tanto, se vive como "cristiano", pero con los mecanismos internos de una religión fácil. Por otro lado, la condición hermenéutica, muy lejos de lo que implica para el cristiano como explicaré, hace que la persona acoja la realidad como fragmento y, por ello, no dudará en cambiar de planteamientos, aunque opuestos, porque la realidad es compleja e inaprensible; la vida se desvela en pequeños fogonazos y hay que cambiar como sea ante las minúsculas intuiciones, siempre que sea a favor de la Vida.

Por fin, antes de pasar a la parte de mi propuesta, la conclusión del fracaso del cristianismo ante esta religiosidad es porque no es fiel a su identidad secular y profética. El mito no necesita fundamentos ni se le piden explicaciones, pero, el cristianismo, aunque se utilice como un mito, tiene al final un Dios responsable de los fracasos, límites y sinsentidos de la experiencia cotidiana de la Vida.

La propuesta cristológica parte de la idea de que Jesús ha introducido una perspectiva nueva para interpretar la existencia, para interpretar la persona en su relación con la humanidad, el mundo y Dios. La Encar-nación y la vida del Jesús histórico introducen el concepto de la secularización como esencia del cristiano, en el sentido de que no hay separación entre lo sacro y el profano, sino relación en la diferencia en su única dimensión existencial, que es la histórica. Por tanto sólo a través de la humanidad, podemos hallar la salvación. La categoría de filiación es decisiva, porque nos hace entender nuestra condición de criatura y co-creador, diferencia entre el Padre, pero continuidad y relación con Él. La secularización y la filiación nos ponen ante la lógica diversa del ser-para-el otro (pro-existencia), del responsabilizarse del otro, para que pueda encontrar su plenitud. He aquí el sentido de la Revelación: vivir en la corresponsabilidad, desde la libertad, para que el otro pueda encontrar su plenitud en la relación mundo-Dios. Por tanto, esta desacralización de Dios nos lleva a una religión existencialpersonalista que implica la denuncia profética siempre que se interrumpa este proceso secular de personalización, plenitud, de salvación.

De frente al fenómeno neopagano nada tiene que ver el cristianismo, porque supone un cortocircuito, ya que éste no vive un dios lejano, inter- 
vencionista, manipulable con sacrificios, sino uno que está presente y que, desde su "ausencia" se deja vivir en la responsabilidad ante el otro ( $C f$. Mt. 25, 40.45), en la pro-existencia. Esta perspectiva de Jesús cambia la manera de vivir la relación con los demás, con la ley, con el culto, con Dios mismo. El concepto de $A b b a ́$ es el que posibilita esta irrupción desacralizante y hermenéutico-secularizante, lo que me llevará al final del capítulo a hacer seis propuestas desde esta nueva perspectiva: antropológica, sociológica, política, teológica, profético-hermenéutica y litúrgica.

De este modo, mi intuición es recuperar, para ofrecer la esencia del cristianismo ${ }^{2}$. Teniendo en cuenta las repercusiones existenciales en los proyectos de vida personales, en la sociedad, en la política, en el mundo, que la religiosidad fragmentada del nihilismo-neopagano ofrecen, el cristianismo se encuentra en su kairós, para recuperar la propuesta existencial que Jesús de Nazaret arrojó en su tiempo, para toda la historia. Un mundo que busca su "sacralización", su autojustificación, permitiendo un decremento personal y humano necesita de un cristianismo fresco, que apueste por el proceso de humanización del hombre concreto en su realidad político-social, histórico, personal, sin desviar cargas injustas ni sobre Dios ni sobre la persona.

Espero que la lectura, no sólo sirva para entender el fenómeno religioso y cristiano de hoy día, sino también que ilumine y abra puertas para la recuperación de un cristianismo centrado en la experiencia revelada en Jesús y continuada en la Pascua. La reflexión propuesta pretende ofrecer una intuición que, aparte de dar razón de nuestra fe, haga más creíble nuestra Revelación-fe como propuesta de sentido en el 2008.

\section{LA RELIGIOSIDAD EN EL GOZNE DEL CAMBIO DE SIGLO Y SU INTERACCIÓN CON EL CRISTIANISMO}

\section{EL DIOS GENERAL DE LOS MITOS}

\section{A.1 Límites difusos de la experiencia religiosa ${ }^{3}$}

Las distinciones tradicionales entre religión, misterio, fe, creencia, etc. hoy carecen de valor en un mundo donde los límites del sacro, lo reli-

2 Está latente bajo toda mi reflexión la orientación que, entre otros González Faus propone, reivindica un tiempo de cristianismo humilde, de menor convocatoria, pero partiendo del Kairos para recuperar la autenticidad, la especificidad, en definitiva, la identidad del cristianismo; $C f$. GONZÁlEZ FAUS, J.I., Calidad cristiana. Crisis e identidad del cristianismo, Sal Terrae, Santander 2006.

3 Cf. BUENO DE LA FUENTE, E., España entre cristianismo y paganismo, Madrid 2002, 167-170. Como se verá, no sólo propongo la concomitancia de diversos elementos religio- 
gioso, el cristianismo $\mathrm{u}$ otras religiones tradicionales se funden en un maremagnum prácticamente imperceptible. Como queda ya apuntado en la "Introducción", aunque el fenómeno de la globalización hace que podamos hablar de ciertos fondos comunes en todo el planeta, centraré mi discurso en la experiencia religiosa europea y más concreta en España. Teniendo en cuenta esto, es fácil descubrir que, no sólo en la experiencia religiosa en general, sino en la misma vivencia de los que aún se auto definen como cristianos católicos, incluidos los jóvenes, estos límites son tan difusos que, un así considerado católico, puede mostrar una religiosidad "humana", mientras un adepto de la New âge, podría parecer más cristiano que aquél; considerarse hoy cristiano en España o un creyente en una potencia universal puede no estar muy lejano el uno del otro ${ }^{4}$.

\section{La necesidad de sentido como denominador común 5}

Es cierto que el cansancio metafísico de la modernidad nos lleva hoy día a navegar en un profundo nihilismo, donde la experiencia de sentido o se rechaza de forma absoluta o, simplemente, se desconfía de su existencia. De cualquier forma, el nivel teórico de esta reflexión nos podría apartar de una realidad corrosiva y universal que no puede negar el nihi-

sos en el mismo espacio y tiempo, sino su interacción; y, no sólo el sincretismo del neopaganismo, new âge hacen al acoger elementos cristianos, sino también el sentido inverso, donde el cristianismo acoge códigos diversos de lo que le rodea.

${ }^{4}$ Aunque no contemplaré el hecho de la inmigración, bien es cierto que en nuestra sociedad supone una circunstancia más para poner en práctica esa antropología relacional o pro-existencia como dinamismo integrador y no exclusivista. Hacia ello tienden propuestas del mundo de la sociología como la expuesta en VAllescar Palanca, Diana de, Cultura, multiculturalismo e interculturalidad. Hacia una racionalidad intercultural, PS Editorial, Madrid 2000,337-352 o bien ZAMORA, José A., Ciudadanía, multiculturalidad e inmigración, El Verbo Divino, Estella 2003, 223-241, aunque si bien, Mardones ya constata la dificultad de llevar a cabo esta reintegración de la palabra partida o del logos spermatikós en una sociedad con posturas reactivas como la tonalidad fundamentalista, el localismo nacionalista o la fiebre comunitarista: $c f$. MARDONES, J.M., En el umbral del mañana. El cristianismo del futuro, PPC, Madrid 2000, 127-132.

5 Son muchas las investigaciones, desde la sociología, antropología, teología, psicología, que presentan la cuestión del sentido como crucial en la experiencia humano-religiosa actual; con ello, por una parte, al cristianismo se le abre un horizonte para proponer la fe como propuesta de sentido, al mismo tiempo que se le abre otro horizonte de diálogo y reflexión-convivencia conjunta ante un problema existencial/sociológico común; $c f$. MURO Ugalde, T., Teología fundamental. La vida tiene sentido, Sendoa, San Sebastián 2002, 32 38.195-197; MARDONES, J.M., Postmodernidad y cristianismo. El desafío del fragmento, Sal Terrae, Santander 1988, 23 en un estudio estrictamente sociológico Vv. AA., Informe España 2005. Una interpretación de su realidad social, Fundación Encuentro, Madrid 2005, 205-220. 
lismo. En otras palabras podría decir que la desconfianza o rechazo de una respuesta metafísica o antropológica, que nos lleva a vivir en un mundo donde no existe la pregunta por el sentido, sin embargo no niega otra realidad que aúna a todo ser humano: la necesidad de sentido ${ }^{6}$.

He aquí un problema, que a nivel práctico nos llevará a conclusiones importantes a la hora de esta vivencia difusa y confusa de la experiencia religiosa. Efectivamente el hecho de vivir inmerso en un ambiente nihilista-positivista, no puede negar el hecho de que el hombre, propiamente por su naturaleza, está condenado a vivir con un sentido ${ }^{7}$. Cualquier joven español posiblemente ante la pregunta por el sentido de su vida, no remitirá a un discurso teológico ni religioso, permaneciendo a un nivel de pequeños y efímeros recursos que le proporcionen cierta estabilidad ${ }^{8}$. Es decir, el hecho de no tener un sentido fuerte unificador de la existencia no puede aniquilar por completo la necesidad de sentido como experiencia cotidiana sin la que el hombre no puede vivir. Me atrevería a distinguir entre un nihilismo concebido al nivel teórico y otro práctico, en el sentido de que este último no puede jamás existir, porque negaría la propia esencia de la persona ${ }^{9}$.

De este modo, la ausencia de una pregunta por el sentido no puede negar de ningún modo la necesidad de su experiencia; otra cuestión será

6 Cf. SÁNCHEZ NogALES, J.L., La nostalgia del eterno. Sectas y religiosidad alternativa, Madrid 1997, 38-44. Básicamente el problema para la juventud española hoy es que se ha dado un cansancio metafísico, provocado por respuestas lejanas de la necesidad de sentido, reprimiendo las ansias más naturales de la persona. "El hombre de hoy, especialmente los jóvenes, está sometido a un proceso de represión de sus aspiraciones hacia lo sagrado y lo divino que le han dejado en una situación de desamparo y desencanto. Ni el racionalismo, ni el materialismo, ni el secularismo desacralizador y desmitologizante han podido dar respuesta a las profundas estructuras existenciales del hombre que es pasión por la trascendencia y naturalmente religioso", ibid. 39.

7 "Al preguntarse sobre sí mismo, el hombre está llamado a tomar posición sobre sí mismo: una llamada dirigida indivisiblemente a su inteligencia y a su libertad... El hombre está ante sí mismo como cuestión que le llama a la respuesta", AlFARo, J., De la cuestión del hombre a la cuestión de Dios, Salamanca $2002^{4}, 14$.

8 Recientemente se ha publicado una encuesta en una revista italiana, donde, ante la pregunta sobre las preocupaciones acerca de su futuro encontramos que "il 38 per cento degli intervistati, alla domanda su quale sia il problema personale che più li preocupa, ha risposto: Nessuno. Se il 14,9 è preoccupato per il lavoro, solo l'18 teme per il futuro e lo 0,3 ha paura del terrorismo", Panorama, 20-II-2005.

${ }^{9}$ De alguna manera se va contra toda respuesta holística o globalizante; lo que cuenta es la subjetividad, que, como pretendo mostrar, cae en lo efímero. $C f$. TORRES QUEIRUGA, A., Fin del cristianismo premoderno. Retos hacia un nuevo horizonte, Santander 2000, 40-47, donde critica tanto el antiguo autoritarismo de la fe como el "subjetivismo irracionalista" como respuestas a las necesidades de la situación cultural actual. 
qué papel juegan las diversas propuestas al alcance del hombre ${ }^{10}$. Desde el cristianismo hasta los mitos, desde la filosofía hasta el sacro anónimo son recursos que a lo largo de miles de años han servido para que el hombre encontrara una estabilidad vital, para que construyera un proyecto plenificador de la existencia, para caminar siempre un poco más hacia la verdad. El problema de nuestro tiempo no creo que se centre en que el hombre no busque un sentido existencial, sino del uso indiscriminado, inconsciente $y$ sincrético que hace de las ofertas que tiene en su mano. Ciertamente España está cansada de una respuesta homogénea religiosa, desconfía de que el cristianismo pueda ofrecer algo adecuado para las expectativas y aspiraciones concretas/cotidianas de hoy, pero ante este rechazo nihilista-metafísico, la necesidad práctica del sentido cotidiano hace que el hombre, ante la dispersión de recursos eche mano según la necesidad, para andar adelante en un mundo demasiado enigmático, sufriente, pesado y dañado ${ }^{11}$.

\section{La auto-satisfacción de la necesidad de sentido como piedra angular}

Efectivamente es fácil concluir que, ante la concomitancia de un nihilismo-positivista y la necesidad de encontrar un proyecto vital, el criterio para cubrir tal urgencia no puede ser la asunción de un esquema antropológico-metafísico estable, cerrado, determinado (excluiría el primer presupuesto en el que vivimos), sino centrarse en la propia necesidad como criterio de búsqueda. Es decir, si no hay ya un sentido fuerte, porque la realidad, la verdad no es uniforme, debe ser el sujeto como ser hermenéutico el que busque "su" fundamento12.

10 Planteamos que toda persona, cristiana o no, con una dimensión religiosa o sin ella, padece a lo largo de su vida experiencias de vacío, de muerte, de náusea, de lejanía, de abandono, pero también de rescate, de re-creación, de reconocerse reconocido y comprenderse comprendido. Pues bien, estas últimas son manifestación de una tensión hacia la plenitud existencial, profundidad de sentido, aunque la persona no las haya buscado, reflexionado o provocado.

11 Así el Concilio Vaticano II intuyó que el mensaje de Cristo es universal, para llegar a la verdad de Dios y del hombre, es decir, ofreciendo propuestas concretas ante los problemas de la humanidad. "Por consiguiente, a la luz de Cristo, Imagen del Dios invisible, Primogénito de toda criatura, el Concilio pretende hablar a todos para iluminar el misterio del hombre y para cooperar en el descubrimiento de la solución de los principales problemas de nuestro tiempo", $G S 10$.

12 La hermenéutica, no obstante, entendida positivamente nos abre, también en el horizonte teológico, a una concepción ontológica del lenguaje, por el cual constituye una función de apertura de sentido. El problema que quiero delinear es el hecho de absolutizar toda interpretación, cayendo en una tiranía del sujeto, es decir en una falta de "respeto" al texto, a la verdad. De ahí que una de las críticas urgentes de Gadamer y Ricoeur a Heidegger fueran la advertencia de hacer coincidir sentido y verdad. "La apertura de sentido es, ciertamente, una 
Si no existe más la confianza en un proyecto común ${ }^{13}$, en una gran narración ${ }^{14}$, en una metafísica fuerte y homogénea, el paso a la hermenéutica está servido. Somos seres hermenéuticos (aunque nadie se presentará así conscientemente), porque intuyendo, interpretando como sujetos nuestra parcela de realidad intuimos algo de la profundidad que nos rodea ${ }^{15}$. Por tanto, ante esta creatividad del sujeto y de frente a la urgencia práctica de la necesidad del sentido, dicha necesidad debe ser satisfecha a la carta, porque cada uno debe activar sus mecanismos para desenvolverse en la realidad fragmentada ${ }^{16}$.

En definitiva, la concurrencia de un desencanto metafísico sumado a una exigencia práctica de respuesta hace que cada cual busque su clave,

precondición de la verdad de los enunciados, pues prejuzga el horizonte bajo el cual aparece el ente; abre el campo de juego de la posible verdad de los enunciados bajo determinadas condiciones. Pero no se identifica con la verdad. Ésta presupone una diferencia sujetoobjeto y una intervención corroboradora del juicio que permita la comprobación o justificación de lo que afirmamos sobre la cosa", SÁEZ RUEDA, LUIS, Movimientos filosóficos actuales, Madrid 2001, 234-235.

${ }^{13}$ Efectivamente la falta de confianza en la humanidad (Greinacher), poca esperanza en el sentido de la misión y el destino de la humanidad, en definitiva nos han llevado, como veremos a una moral narcisista que el neopaganismo y el desencanto nihilista han acogido y proyectado. Cita indirecta de BAUDRILLARD, J., El otro por sí mismo, Barcelona 1988, 34-35 en NATAL, D., "Hacia un cristianismo postmoderno" en Estudio Agustiniano, Valladolid 1990 (XXV), 17: "Hoy la ley es: a cada cual su burbuja [...] Anteriormente, la obsesión consistía a parecerse a los demás y perderse en la multitud. Obsesión de la conformidad, manía de la diferencia. Hace falta una solución que nos libre de parecernos a los demás. Hoy consiste en parecerse únicamente a uno mismo".

14 Se da una total desconfianza en las grandes ideologías y teorías globalizantes (comenzando por el cristianismo), porque han enmascarado la realidad en vez de revelarla (pensemos que para el cristianismo no puede ser más corrosivo este pensamiento). Cita indirecta de LIPOVETSKY, La era del vacío, Barcelona 1986, 114-115 en NATAL, D., "Hacia...", 16: "el estallido de los grandes relatos: instrumentos de la igualdad y de la emancipación del individuo liberado del terror de los megasistemas, de la uniformidad de lo verdadero y por ello a merced de la inestabilidad experimental y de los 'contratos temporales', en estrecha congruencia con la desestabilización y particularización del narcisismo. La denuncia del imperialismo de lo verdadero es una figura ejemplar del postmodernismo".

15 Cf. PIÉ-NINOT, S., La teología fundamental, Secretariado Trinitario, Salamanca $2006^{6}$, 205ss. Allí Pié-Ninot recoge nombres de teólogos actuales que, a partir del sentido ilativo de J. H. Newman plantean un asentir personal y no sólo nocional-cognoscitivo, como uno de los tantos modos renovados de entender la fe en su relación con la razón y la manera de conocer, penetrar la realidad.

16 "La razón, en cuanto un todo único, sólo tiene justificación como un símbolo abstracto que cada vez encuentra menos apoyo en la realidad histórica, social, cultural, en la que opera activamente. Y, como vamos a ver, no sólo la razón en cuanto lugar integrado de la racionalidad es insostenible, sino que las visiones integradas, totalizantes, de la realidad parecen imposibles": MARDONES, J.M., Postmodernidad y cristianismo. El desafio del fragmento, Santander 1998, 24-25. 
con la consecuente inestabilidad, fugacidad, individualidad y practicidad de este "sentido". Desde esta perspectiva afirmaba que la urgencia de la necesidad, sin un fundamento al que aferrarse, tiene como consecuencia poner en el centro la satisfacción como piedra angular, como criterio de la búsqueda del sentido ${ }^{17}$.

\section{La religiosidad al servicio del (la satisfacción) hombre}

Por tanto, sería justo hacer un reconocimiento positivo de esta religiosidad neopagana o mítica, ya que, de alguna forma, está dirigida al hombre, sirve para dar respuestas a las exigencias concretas existenciales en el aquí y ahora. El problema, sin duda alguna, es ver qué tipo de servicio hace al ser humano, ya que una religiosidad que no está dirigida al hombre no tiene sentido, pero una que no respeta la divinidad, nos hace caer en una autorreferencialidad que, a su vez, nos lleva a una religiosidad individualista, cómoda.

En efecto, el problema del discurso religioso en nuestros días no debería ser solamente que la posible caída o disminución del cristianismo se debe a una falta de humanización para la persona del siglo XXI, mientras que la nueva religiosidad se pone al servicio del hombre. Ciertamente este es el aspecto positivo que nos debe llevar a repensar que no hay cristianismo-cristología, si no hay antropología. Pero, al mismo tiempo, debemos reflexionar y no caer en una vacuidad de planteamientos, porque... ¿qué clase de servicio promueve este tipo de religiosidad general? ¿Qué antropología fomenta esta vivencia neopagana? ¿Ayuda a la revalorización del hombre, a una antropología integrada, a una verdadera transformación de la humanidad? Evidentemente, no ${ }^{18}$.

Cuando hoy día los partidos políticos exigen que la dimensión religiosa permanezca al nivel privado, sin que tenga consecuencias en la vida social y se junta con esta vivencia neopagana, siempre presente en Europa

17 Valorando positivamente la capacidad de respuestas inmediatas de la postmodernidad, leemos la confusión de identidad que provoca esta fugacidad y subjetividad cerrada radical. Tanto lo bueno como lo malo, lo falso y lo verdadero, todos los extremos se han vuelto más débiles; la vida se vive en secuencias: Cita indirecta de BAUDRILLARD, J., Las estrategias fatales, Barcelona 1984, 179 y ss en NATAL, D., "Hacia...", 26.

$18 C f$. GS 22. Hoy más que nunca la reflexión teológica debería tener en cuenta que cualquier afirmación cristológica debería estar versus hominem, revelándole su identidad, su proyecto de vida. Al igual que la problemática del hombre no puede sino suscitar un necesario nuevo acceso al misterio-identidad de Jesucristo. Cf. ApARICIo VAlls, C., La Plenitud del Ser Humano en Cristo. La Revelación en la "Gaudium et Spes". Tesi Gregoriana, Serie Teologia 17. Roma, PUG 1997. 
y en la humanidad, caemos en el peligro, actualmente ya vivido, de justificar cualquier sistema social, quedando lo religioso como un recurso para restablecer el equilibrio del sistema personal y social, sirviendo como un analgésico para mis necesidades cuando tengo necesidad. Concluyendo diría que el neopaganismo aporta al hombre respuestas, métodos de reacción concretos dirigidos al hombre, pero no para su humanización, sino para su justificación y, con ella, la del sistema social ${ }^{19}$. Se hace un dios o divinidad tan personal (individual) que al final, queda como construcción filosófica trascendente, lejana de la realidad, que no cuestiona la realidad, porque no es su labor; sólo queda como aquello a lo que recurrimos ante la necesidad de una satisfacción o re-estabilización del sistema ${ }^{20}$.

\section{El cristianismo al servicio de la plenitud del hombre}

Si comenzaba el sub-apartado anterior reconociendo la dimensión positiva de esta vivencia mítico-neopagana, en contraste, propongo lo contrario para el cristianismo. Tal vez uno de los grandes males de los últimos tiempos para el cristianismo ha sido perder una clave fundamental que pertenece a su propia esencia, identidad: la humanización, la kénosis, la encarnación, la secularización 21 .

Efectivamente, parece que se ha olvidado la frescura del párrafo ya señalado de la GS 22, donde se nos recuerda que la máxima plenitud de la Revelación de Dios ha supuesto la máxima Revelación de la plenitud del hombre 22 . El cristianismo no puede ser, existir, si no es en la lógica de la humanización del hombre y, hoy, de frente a la religiosidad general de

19 Hoy vemos cómo Europa se encuentra en una búsqueda de identidad, donde las fuerzas que irrumpen con más poder: "la fe cristiana, el racionalismo científico y el vitalismo neopagano", Bueno DE LA FUENTE, E., España..., 211. Para tener una intuición general de lo que aquí planteo $C f$. ibid. 195-263, donde se hace una reflexión que intenta mantener que la esencia pagana de Europa, más antigua que el cristianismo, nunca ha desaparecido, eclosionando en nuestros tiempos ante una situación de crisis.

${ }^{20} \mathrm{Y}$ es que el problema de este individualismo es que, en ningún nivel de la vida, tiene ni quiere tener un punto de contacto con los demás, porque "ante la carencia de un proyecto universal, el hombre occidental se refugia en la subjetividad, en la esfera privada y en el culto a la individualidad: un narcisismo que dirige su atención al presente y al goce no pospuesto de los múltiples incentivos con que le bombardea la sociedad consumista", MARdones, J.M., Postmodernidad..., 153.

21 Siguiendo a Vattimo y en superación del nihilismo Nietzscheano, de lo sagrado violento de Girard y del olvido del ser Heideggeriano, proponemos la coincidencia entre la Revelación bíblica kenótica y el debilitamiento de la metafísica del ser y la secularización. Cf. VAtTimo, G., Creer que se cree, Paidós, Barcelona 1996, 38-39.41-42.50.54 (sobre todo).

22 Cf. GS 22;Cf. DV 2, 6. 
los mitos es un tanto que hemos perdido, porque no estamos a la altura de dar una respuesta al hombre 23 . La centralidad del sujeto de la fe no puede pasar desapercibida en un mundo que necesita vestigios de salvación ${ }^{24}$.

La encarnación de Jesucristo nos recuerda la apuesta de un Dios que hace Alianza, de la interrupción total de la vivencia-experiencia religiosa, ya que la "divinidad" entra en la historia, pero no para pasearse como las divinidades mitológicas y divertirse entre los hombres, sino para afirmar que es en la historia, en la humanidad, en la carne, en la existencia concreta donde se hace presente y donde está nuestra plenitud 25 . Por tanto, en este sentido, la kénosis supone para nosotros un principio de secularización del divino, una apuesta por la existencia real como medio para llegar a la máxima plenitud ${ }^{26}$. Por lo tanto sólo a través del compromiso e implicación con lo real, se puede llegar a realizar la máxima vocación del hombre, la humanidad, la historia 27.

${ }^{23} C f$. $G S 1,3,9,12,14,22,27 \mathrm{y}$, en general toda la segunda parte donde se intentaba afrontar los problemas concretos de aquel tiempo; $C f . D V 2,4,6$.

24 Cf. Pottmeyer, H.J, "Centralità del soggetto della fede o del contenuto della Rivelazione? La recente discussione tedesca sul discorso della teologia fondamentale", www.unigre.it/pug/teofon/studio.htm/centralita.htm, en el que se nos ofrece, a partir de la orientación de Verweyen, la necesidad de poner en relieve al sujeto-testigo de la Revelación en la mediación de la misma.

25 Para una interpretación bíblica sobre la secularización de la existencia $c f$. EsTRADA, J.A., El cristianismo en una sociedad laica. Cuarenta años después del Vaticano II, DDB, Bilbao 2006, 112-120. Y más claramente sobre el proyecto desacralizador/secularizante del Dios de Jesús que vincula el proyecto del Reino de Dios con el carácter inmediato de acontecimiento creacional y liberador: VIDAL, S., Jesús el Galileo, Santander, Sal Terrae 2006, 125: " Ese carácter histórico y creacional del acontecimiento del Reino de Dios está bien marcado en toda la misión de Jesús. Es más, adquiere en ocasiones un tono de inmediatez y realismo que se podría caracterizar auténticamente como desacralizador. Lo que la proclamación y actuación de Jesús transparentan no es, ciertamente, un mundo sagrado estereotipado, sino el mundo inmediato de la creación y de la vida, que se convierte así en verdadera parábola del Dios inmediato creador".

26 "La Revelación cristiana se diferencia del paganismo ante todo porque es el relato, la narración, de una historia de alianza que se prolonga hasta el presente y que invita a todos los hombres a un protagonismo personal. No es ni la formulación de principios racionales ni experiencias de solidaridad cósmica ni intensas conexiones con la Vida": BUENO DE LA FUENTE, E., España...., 296; en general puede consultarse todo el capítulo sobre "la originalidad de la insolencia cristiana", cf. ibid., 296-303.

27 Esta idea de que sólo a través de lo real hay salvación o verdadero encuentro con Cristo o verdadera humanidad (serían diversos matices de la misma realidad-la creación) nos lo ofrece el concepto de Revelación expresada en $D V$ y que muchos teólogos han desarrollado; valga como ejemplo el comentario de Latourelle en su comentario a Pascal: "La sintesi che riunisce tutto, si produce per via di superamento. Cristo rischiara tutto, descifra tutto, ma come mistero d'amore. La traccia vuota dell'amore perduto non permette all'uomo di misurare, soltanto attraverso essa, la distanza reale che lo separa dalla sua vera natu- 
Como veremos más adelante, esta propuesta del Dios de Jesucristo va contra la idea de una religiosidad privada alejada de la vida social, comunitaria, apartada del progreso y promoción humanas y radicalmente opuesta a la estabilidad e injusticia. Por tanto, como juicio negativo podemos ser justos si reconocemos la falta de una mirada hacia el hombre, hacia las exigencias concretas de nuestros tiempos, pero como valoración positiva, podremos afirmar que la Revelación de Jesucristo nos ofrece en el año 2008 un cristianismo prácticamente por estrenar, ya que nuestras vivencias religiosas concretas se han quedado más en un dios omnipotente trascendente (puro mítico), que en el que ha elegido la humanidad, la existencia concreta para mostrar otro rostro de Dios en la humillación, en el dolor o, simplemente, en la cotidianeidad de la vida a través de una inversión de los valores 28 .

\section{A.2 Presencia de elementos paganos, precristianos y anticristianos}

No cabe duda que debemos admitir que el escenario de la religión ha cambiado con un giro copernicano, que nos lleva a reflexionar sobre el sentido más auténtico de la secularización del cristianismo ${ }^{29}$. En efecto, hay quien confunde la gran corriente de secularismo con la secularización, inherente a la esencia de nuestra religión ${ }^{30}$. Este emerger de las tenden-

ra. Il rapporto tra i due stati si manifesta solo al momento in cui il legame di Dio e dell'uomo, nell'unione ipostatica, del redentore e del peccatore, dell'eletto fatto reprobo, congloba i due stati e produce una mutazione dei valori", LATOURELLE, R., L'uomo e $i$ suoi problemi alla luce di Cristo, Assisi $1995^{2}, 101$.

28 Cf. Salmann, E., La palabra partida, Cristianismo y cultura postmoderna, PPC, Madrid 1999,36-41, donde plantea el "poder sufrir, presentando a la persona como herida del ser": "el nacimiento, la maravilla, la consciencia, el diálogo...En todas estas formas de la via aparece la lesión y la fractura. Todas ellas soportan el remolino de la sustración y un proceso de desilusión (36-37) [...] Tendría que ser un Dios que turbase e interrumpiese las vías y los círculos de la pseudopotencia humana. Es cierto que un tal Dios no explica mucho las cosas, pero quizá sea un Dios que salve. Así las cosas, Dios sería el punto débil de las religiones, de cualquier sistema y pensamiento. Sería Aquel que nos haría intuir que cada pensamiento y realidad presuponen algo misterioso, un fondo que nunca es completamente agotable. Con un Dios asó podría recomponerse el espacio simbólico de nuestra existencia (41)".

29 "Il fatto che Gesù sia autenticamente umano e che, proprio per questa autenticità sia il Rivelatore, struttura tutta la teologia a titolo di principio; deve essere preso sul serio", DuQuoc, C., Cristologia, Brescia 1972, 342.

$30 \mathrm{Sin}$ llegar a las últimas consecuencias de las teologías del mundo, política, liberación... resulta interesante distinguir correctamente los dos términos que entran en juego y que, según Gogarten, son bien distintos: "Per Gogarten, la secolarizzazione è il prodotto della fede cristiana. Essa consiste nella liberazione dell'uomo dalle forze del mondo, liberazione provocata dalla fede, che modifica il rapporto dell'uomo con la storia. In senso inver- 
cias neopaganas, neomitológicas son contempladas por algunos como un renacer, como una novedad en la España de nuestros tiempos, sin embargo, otros afirman que España, como Europa sólo reflejan el resurgir de una herencia más antigua que el cristianismo, que eclosiona exageradamente hoy día debido a su continuo sofoco durante siglos con respuestas que han negado o andado en contra de la vida31.

Por tanto no es que surja ahora un nuevo tipo de religiosidad (ciertamente sí, respecto a la generalidad de lo inmediatamente antes vivido), sino que explosionan los elementos paganos, precristianos y anticristianos que han pertenecido a la esencia de España, que han configurado la respuesta religiosa existencial de muchos siglos antes de la llegada del cristianismo y, después, en concomitancia con él32.

\section{El escenario de la experiencia religiosa}

Después de un cansancio metafísico ${ }^{33}$, donde se ha olvidado la frescura de un Dios personal, relacional que viene al encuentro del hombre y se ha mostrado un tipo de elucubraciones que lo han matado, llegamos a una época, en la que, además de tener encerrado a Dios en conceptuali-

so essa significa una mondanizzazione del mondo, la fine dell'era mitica. Per capire questo nuevo rapporto, Gogarten riprende i due concetti biblici di filiazione e identità [...] Per lui (Gogarten), si opera una perversione della storicità per cui la direzione presa dal divenire del mondo rimane sempre avvolta nel mistero. La secolarità è l'accettazione della storicità umana. Il modo in cui l'uomo, credente o no, si situa in rapporto al futuro come un essere in perpetuo divenire e ricerca, lo mantiene nella secolarità. Se l'uomo pretende di determinare lui stesso la direzione della storia e per questo stesso fatto cessa di relativizzare i suoi progetti attuali, affonda nel secolarismo", LEFEBVRE, S., "Secolarità" en LATOURELLE, R.Fisichella, R., Dizionario di teologia fondamentale, Assisi 1990, 1095.

También $c f$. EsTRADA, J.A, El cristianismo, 109-169, donde matiza y precisa los conceptos de secularización, secularismo, laicidad y laicismo, así como su desarrollo histórico en España.

${ }^{31}$ Me hago eco de la idea que sugiere que "el paganismo, que no ha desaparecido de la historia europea, y que incluso ha sido reivindicado para revitalizar a una Europa cansada" es un resurgir de las raíces religiosas paganas que siempre han existido en España y en toda la humanidad. BUENO DE LA FUENTE, E., España..., 195.

32 De hecho es una reflexión que no es nueva en absoluto como lo demuestra el hecho de la publicación de Danielou, J., Miti Pagani, Mistero Cristiano, Roma, 1995, cuya primera edición es del año 1966 y donde expone el componente mítico, ya no sólo del cristianismo, sino de toda religión.

33 No sólo hay un horror metafísico, como afirma Mardones "la pretensión de una filosofía o sistema de poseer el verdadero acceso a la realidad aparece como una ilusión. No sólo la antigua metafísica, sino los críticos modernos, ilustrados y filósofos del idealismo alemán, así como la misma ciencia, le parecen a Nietzsche meros sustitutos pretenciosos de aquella", MARDoneS, J.M., Postmodernidad..., 22. 
zaciones vagas, está tan lejano de dar respuesta a los hombres que ya no es más el Enmanuel, sino el totaliter alter ${ }^{34}$, que en el peor de los casos además justifica tantas injusticias ${ }^{35}$.

Nos encontramos ante un mundo desencantado por la razón y por la religión ${ }^{36}$. Ya no estamos encima de un escenario uniforme, donde la religión cristiana ofrecía un esquema de respuestas fijas para todo creyente, sino ante una pista móvil, donde no hay sentido de definitividad ${ }^{37}$. El descubrimiento de la falacia de la emancipación de la razón ha llevado al hombre a un horror vital, porque ni el Dios metafísico ni el propio hombre pueden llevar a la emancipación ni, mucho menos, a la salvación. Ni que decir tiene que, ante el peso y vaguedad de la vida, el hombre ha reaccionado buscando el amparo de algo que pueda llenar ese hueco, de, como decíamos en el apartado anterior, responder a la necesidad de sentido y el peso de la vida ${ }^{38}$.

\footnotetext{
34 No deja de ser significativo el estudio que, ciertas orientaciones sociológicas proponen, sobre la concepción de lo sagrado. Efectivamente, perdiéndose cierto nivel de la secularización, se pasa a la religión de lo sagrado, pero no para quedarse en la trascendencia absoluta, sino para confundir lo sagrado con "ese fondo interior de la persona que está más adentro que las ocupaciones profesionales, las preocupaciones económicas, los cuidados de la salud, la actividad exterior, lo medible y palpable. Es ese espacio interior en el que el hombre o la mujer toma conciencia de su yo, de su dignidad y gusto por la belleza y la contemplación. Es esa zona intocable, inviolable, intimamente íntima. Esa intimidad es sagrada. Buscarla y cultivarla es practicar la religión de lo sagrado": CESC, Informe España 2005. Una interpretación de su realidad, Fundación Encuentro, Madrid 2005, 209. Me parece que esto es la radiografía del neopaganismo, que proyecta la intimidad hacia la trascendencia, cayendo en un nivel de intimismo/individualismo religioso y ético, al mismo tiempo que coloca inconscientemente esa intimidad en un espacio trascendente inviolable.

${ }^{35}$ Cf. Ef 2,$18 ; 2$ P 1,4; Jn 15,14-15.

36 "En terminología religiosa, la disolución de la verdad viene expresada por "la muerte de Dios". Es decir, ya no hay ningún fundamento (Grund) fijo sobre el que quepa asentar o creer algo como seguro e inconmovible. Sólo nos queda, como dirá Vattimo, el vagabundeo incierto. No hay caminos que lleven a un fin, a una realidad. Todos son, dirá Heidegger, senderos perdidos, interrumpidos, cortados en algún lugar, que sólo permiten errar en una continuidad donde la única lógica es la contigüidad", MARDONES, J.M., op. cit., 23.

37 MARDONES, J.M., Recuperar la justicia. Religión y política en una sociedad laica, Santander 2005, 217: "El hombre de la modernidad tardía, o postmodernidad, renuncia incluso a la voluntad de la autofundamentación ilustrada. Sabe que sabe poco, acepta la radical contingencia y falibilidad del pensamiento y del lenguaje mismo, y propone decir adiós al concepto de verdad y sustituirlo por el de persuasión. Una teología crítica y avisada sabe que su hablar del Misterio es siempre analógico, simbólico, débil".

38 "Justamente lo que caracteriza el impulso postmoderno es la implantación de la razón pluralista sin lamentos. En la terminología de la tradición wittgensteiniana, se trata de aceptar la irreductible pluralidad de juegos del lenguaje, sin aspirar a acuerdos o consensos que no sean temporales y locales", MARDONES, J.M., Postmodernidad..., 69.
} 
He aquí que surgen con todas sus fuerzas los elementos aletargados de la Europa precristiana, cuando no anticristiana, para dar una "asidera" distinta de una ontología, metafísica fuere, así como de una religiosidad muerta y poco fiable. Poco a poco, por su misma constitución, cuando la vida ha sido sofocada bajo la presión de la razón y la religión, ha sido la misma Vida la que ha estallado en medio de la cotidianeidad, haciéndose paso y resultando el criterio absoluto de la existencia; Dionisio, el dios de la Vida, ha recordado ante la desesperación del hombre, que es en la misma vida donde encontramos nuestros pequeños criterios para vivir, disfrutando de ella y resolviendo los minúsculos obstáculos que osen ponerse en medio de su deleite.

\section{Elementos culturales antiguos}

Más adelante veremos cómo subyace una vivencia interna de esta nueva religiosidad pagana, cómo existe una "espiritualidad" que atraviesa toda manifestación religiosa, por no decir que se hace presente en cada situación de la vida, porque, tal vez hoy como nunca se vive religiosamente. Sin embargo en este apartado, querría mostrar que, lejos de ser una intuición que se respira de lejos se trata de una constatación con manifestaciones muy concretas en lo cotidiano, cada vez con mayor extensión, variedad y profusión entre los jóvenes ${ }^{39}$.

Los rituales vetustos, estáticos y ajenos de las celebraciones cristianas han sido sustituidos por los grandes recintos de la música y el deporte ${ }^{40}$. La capacidad de canalizar la potencia de la Vida que estos espacios ofrecen, deja de lado la compresión y represión que los rituales cristianos hacen de ella. Se vive más una especie de fraternidad, de ser-en-el-mundocon en estos ambientes que en la celebración que llamamos por excelencia de la comunión. Las ritualidades del vestuario, del comportamiento se hacen externas y unánimes; se paga por ello, se hacen filas ilimitadas y se crea una expectación entorno al evento, surgiendo propiamente un "adviento", un tiempo de preparación, ilusionada, donde hasta el último detalle es pensado y tenido en cuenta, para que, llegado el momento, el poder de la Vida pueda explosionar en una comunión mística, donde la

39 Cf. ibid., 105-110 y Torres QueIruga, A., Fin del..., 96-100.

40 La demanda de un cristianismo lúdico, festivo, participativo y celebrativo es muy urgente. "La vivencia religiosa u ofrece más felicidad y sentido que el hedonismo consumista y el materialismo de la frívola levedad de la vida, o tendrá que capitular ante esta sociedad del espectáculo": MARDONES, J.M, La indiferencia religiosa en España. ¿Qué futuro tiene el cristianismo?, Ediciones HOAC, Madrid 2004², 167. 
experiencia te pueda hacer fundir con la irradiación de las otras vidas ${ }^{41}$. El baile, los gritos, las canciones, la violencia, la bebida, la droga, el sexo son expresiones de esa confluencia de la potencia de la Vida ${ }^{42}$.

Parece que después de 20 siglos, el paganismo ha estado reprimido bajo las expresiones cristianas y los dioses de los solsticios se despojan de las cadenas soportadas injustamente. El revestimiento de la Navidad, del nacimiento de Juan Bautista han oprimido un sentir cósmico, una celebración universal. De hecho, hoy día, aunque no se celebre más la Navidad, sigue siendo un momento donde todo el mundo se para y festeja, es un impacto universal. Celebramos fiestas cristiano-paganas, pero sin ser conscientes de que los antiguos dioses se han quitado el polvo de sus losas y han vuelto a pasear entre los habitantes de la tierra. De igual modo, el carnaval, Halloween, la semana blanca (como evento más reciente) son fiestas que se han transformado en medios para expresar esa eclo-

41 Merece la pena leer el análisis de las celebraciones "litúrgicas" del neopaganismo que Mardones hace: maquillajes, operaciones estéticas, estadios de fútbol, conciertos, botellón...todos obedeciendo a una cosmovisión, moral que comporta una ritualización común y bien definida. Cf. MARDONES, J.M., Para comprender las nuevas formas de la religión, Verbo Divino, Estella 1994.

42 Efectivamente se da una confusión del rostro de dios como consecuencia, según Sánchez Nogales de un proceso de represión de las aspiraciones de los jóvenes hacia lo sagrado (Cf. op. cit., 39). SÁNCHEZ NoGALES, J.L., La nostalgia..., 39-40: “El fenómeno es desconcertante. Decadencia de las religiones institucionales y de las grandes tradiciones religiosas y, contrariamente, multiplicación de al religiosidad alternativa, especialmente la sectaria. Fenómeno particularmente notable entre los jóvenes. El despego de los jóvenes de la fe de sus padres se ha generalizado. Paralelamente, esta ruptura corre pareja con un interés sin precedentes por lo religioso en todas sus formas. Al mismo tiempo que las iglesias se muestran cautas en hablar de lo sobrenatural -vida interior de la gracia, eventos salvíficos sobrenaturales, realidades últimas, escatología, etc.- se asiste a un interés espectacular por lo oculto: magia negra, astrología, espiritismo, canalismo (channeling), telepatía, parapsicología, culto ufológico, encuentros en la tercera, cuarta o quinta fase, tarot, futorología, gusto por las técnicas orientales de relajación y meditación, etc. [...] Como ejemplo de este retorno de lo reprimido en la religiosidad alternativa, concretamente en la llamada nueva religiosidad, se citan las especulaciones en torno a una visión holonómica. Ésta ha sido puesta de relieve por los autores de la new age, además de F. Capra, especialmente por Ken Wilber. La visión holonómica o paradigma holográfico (también holístico) consiste en una nueva teoría o modelo de comprensión del universo. Entiende el universo como un todo orgánico y homogéneo. En el universo, las realidades particulares no existen; sólo existe una única, misma y homogénea realidad. Lo que a nosotros nos parecen cosas particulares o individuos no son sino reflejos parciales, facetas o caras de esa única realidad universal. No hay diferencia sustancial entre el hombre, el animal y el mundo inorgánico. Ni dentro del hombre hay diferencia esencial entre lo corporal, lo psíquico y lo espiritual. Forman parte de un todo del cual son aspectos particulares. Se trata de una visión casi espiritual, del mundo, en la cual la multiplicidad es la ilusión y sólo existe la unidad del ser. Se tiende, así, un puente entre la interpretación de la física atómica y la filosofía religiosa oriental". 
sión de la potencia vital y, siempre, posibilidad de fundirse en esa armonía cósmica, en ese maremagno en el que todos vivimos ${ }^{43}$.

Elementos culturales como el Papá Noel, el árbol navideño, la fuerza de la música celta o de influencia precristiana, las decoraciones célticas de los pubs (santuarios juveniles), la marroquinería o complementos de belleza precolombino, oriental, celta, hacen entender la revalorización de tales en la vida cotidiana como expresión de un sincretismo brutal. Los jóvenes españoles aún se pueden reconocer cristianos, pero en concomitancia con actitudes, éticas, vestuarios, tendencias sociales, opiniones, creencias totalmente paralelas, porque el Dios de la Vida es la vida misma y para las personas y, por ello, el Dios de Jesucristo no estorba siempre que entre en este código: crucifijo, amuleto celta, colgante onomástico, signo del donante... cuelgan de la misma cadena. 44

\section{Espontaneidad como moral}

Lógicamente el problema no reside sólo en tal o cual manifestación, es decir en lo que podríamos denominar una crisis de identidad, sino también en el hecho de que a toda crisis de identidad corresponde una de moral ${ }^{45}$. Efectivamente no sólo se crea una especie de caos moral donde todo vale, sino que tampoco se es capaz de fundamentarlo. Se legitima en un fundamento "falsamente hermenéutico", donde, en definitiva, el criterio último es autojustificar mi comportamiento, porque el yo, la persona es criterio absoluto y cada uno puede y debe gestionar su vida sin que nadie le prive de ese derecho ${ }^{46}$.

En contraste con una ética ya pasada del trabajo y el ahorro, propia de la modernidad, la ética actual afirma el valor del consumo ${ }^{47}$, el tiempo libre y el ocio ${ }^{48}$. Pero esto no podría funcionar sin la exaltación del individualismo, la devaluación de la caridad y la indiferencia hacia el bien

\footnotetext{
43 Habría que destacar que, el gran templo neopagano donde se celebra la fiesta semanal y se aglutina la asamblea festiva, es lo que la sociología denomina no-lugar. El espacio y tiempo cristianos no configuran el ritmo social ni dan sentido ni identidad, sin embargo los no-lugares (calles, parques), que suelen ser expresión-prolongación de la Naturaleza, pasan a convertirse en lugares es decir en un "espacio físico o simbólico que responde a una función identificadora, relacional e histórica, que ofrece un principio de sentido a quien lo frecuenta": GAmbini, P., Al encuentro con los jóvenes de la calle, CCS, Madrid 2005, 60.

44 Cf. BuENo de LA FuENTE, E., España..., 172-177.

45 Ante la moral de obediencia que todavía propone el cristianismo surge con más fuerza y oposición la vida fácil del hedonismo; $c f$. ESTRADA, J.A., El cristianismo..., 234-235.

46 Cf. Mardones, J.M., Postmodernidad..., 68-72; Cf. Lipovetsky, G., La era..., 60 y ss.

47 Cf. Lipovetsky, G., El imperio de lo efímero, Barcelona 1990, pp. 225-231.

48 Cf. LiPovetsky, G., La era del vacio, p. 14.
} 
público ${ }^{49}$. La búsqueda de gratificación, de placer y de realización privada es el ideal supremo. La adoración de la independencia personal y de la diversidad de estilos de vida se ha transformado en algo importante ${ }^{50}$ El pluralismo provee una multiplicidad de valores, con muchas opciones individuales, pero ninguna de ellas auténtica. Las diferencias ideológicas y religiosas son tratadas superficialmente como modas ${ }^{51}$. La cultura de la libertad personal, el pasarlo bien, lo natural, el humor, la sinceridad y la libertad de expresión emergen hoy como algo sagrado52. Lo irracional se legitima a través de los afectos, la intuición, el sentimiento, la carnalidad, la sensualidad y la creatividad53. Todo esto ocurre en el marco de un axioma aceptado por casi todo el mundo: un mínimo de austeridad y un máximo de deseo, menos disciplina y más comprensión ${ }^{54}$.

Teniendo como objetivos diarios el placer, la salud, la fiesta se busca incesantemente un culto desmesurado a lo externo, principalmente el cuerpo55. El cuerpo es la manifestación externa de esa potencialidad vital, expresión del vigor de la vida y, por ello se debe cuidar y someter a ascesis increíbles, para poder triunfar en el desafío de cada día. No ayunamos para la cuaresma ni nos preparamos para la reconciliación ni sacrificamos el tiempo en la catequesis, pero podemos hacer cada día una cena de un vaso de leche, para mostrar un cuerpo esbelto, o bien podemos hacer todo un ritual de 3 horas para salir un sábado, o bien entrenar 3 veces a la semana, para jugar en nuestro equipo. Está claro qué tipo de sacrificios se está dispuesto a hacer y cuál es el criterio que los unifica ${ }^{56}$. Gozar de una salud y apariencia externa excelente, para explotar al máximo las posibilidades de la vida ${ }^{57}$.

49 Cf. LiPOVETSKY, G., El imperio de lo efímero, pp. 201, 202.

50 Cf. CECS, Informe, 209-210.

51 Cf. ibid. pp. 313-315.

52 Cf. LipoveTSKY, G., La era del vacio, pp. 7-11.

53 Cf. Lipovetsky, G., El imperio de lo efímero, p. 196.

54 Cf. Lipovetsky, G., La era del vacio, p. 7.

55 La sociedad amenaza de constituirse sobre la pura dimensión estética, necesaria recuperación para el cristianismo, pero, para entender el equilibrio, vivimos en tiempos de una estética sin belleza, que hace necesario, como diría G. Faus, pasar de una "cosmética a una cosmo-ética": cf. GónZALEZ FAUS, J.I., Calidad, 154-168.

56 No obstante, hay que destacar que las penitencias/ascesis neopaganas logran un producto en armonía al esfuerzo invertido; las auto-mutilaciones del "creyente" en Dionisio de transforman en satisfacciones hedonistas (pérdida de peso, mejora estética postoperatoria, simular camaleónicamente la edad...) que contribuyen a autodivinizarse más y anular el sentimiento trágico de la vida. Las penitencias cristianas no acercan a ningún tipo de plenitud de vida, ni histórica ni metahistórica.

$57 C f$. Bueno DE la Fuente, E., España..., 166; MARdones, J.M., ¿Adónde va la religión? Cristianismo y religiosidad en nuestro tiempo, Santander 1996, 38-40. 
Este tipo de enmascaramiento o estetización de la realidad lleva al querer vivir bien, querer sacar el máximo rendimiento al placer. Obviamente en este proceso la moral no tiene fundamento, no hay una opción fundamental que unifique la vida, porque el placer no lo requiere, es más, lo rechaza por principio, porque tener un criterio absoluto sería limitar las posibilidades de su expresión. Es la propia vida, el placer, el embellecimiento quienes buscan en cada momento los pequeños criterios que sirven para actuar con el objetivo de conseguir tal fin 58 .

La gravedad del discurso se condensa, al cruzarse la condición hermenéutica de las personas con esta fragilidad o espontaneidad moral sumado, aún, a un nihilismo ambiental (como diremos en el siguiente apartado) que llevan al sujeto a auto-definirse como criterio absoluto en su actuar. La seducción, lo espontáneo, lo placentero se unen para negar todo fundamento moral; como máximo se niega la posibilidad de dañar al otro, creyendo así que somos los seres más respetuosos del mundo, pero en el fondo es la negación y anulación más sibilina de la vida personal y comunitaria ${ }^{59}$.

\section{A.3 El paganismo como cosmovisión}

Todas estas manifestaciones nos llevan a considerar que el paganismo es una de las formas de religiosidad que ha despertado de la represión del sentido religioso ${ }^{60}$ y que se ha erigido como una visión del mundo con su respectiva ética. Antes de concretar los mecanismos de este resurgir mitológico, expondremos en este apartado las características que uniforman este nuevo modo de asumir y entender la vida.

\section{La eclosión de la Vida}

Ya queda suficientemente subrayado que la Vida es la apuesta grande o el denominador común de la experiencia religiosa hoy61. Esa intui-

58 LIPOVETSKY, G., La era..., 105 en NATAL, D., "Hacia...", 18: “ En este sentido, el postmodernismo aparece como la democratización del hedonismo, la consagración generalizada de lo nuevo, el triunfo de lo anti-moral y del anti-institucionalismo, el fin del divorcio entre los valores de la esfera artística y los de lo cotidiano".

59 SÁNCHEZ NOGALES, J.L., La nostalgia..., 342-343: "No hay ideales morales objetivos a los que aspirar ni criterios ciertos desde los que elegir. Cualquier camino es bueno con tal que ayude a la conciencia a la exploración de nuevas zonas o dimensiones de la realidad. Hay como un ansia de individualizar y subjetivizar las pautas de vida y conducta".

${ }^{60} C f$. nota 2 .

61 Alfaro, J., De la cuestión del hombre, 88: "Todo cuanto Nietzsche ha podido decir sobre los valores nuevos de la humanidad futura se reduce, pues, a proclamar su esperanza 
ción expresada por Sánchez Nogales ${ }^{62}$ sobre la represión de los dones de la vida por parte de la religión y la razón ha provocado que al final, la necesidad más radical del hombre, es decir la nostalgia del eterno ${ }^{63}$, haya emergido pero despojándose de todo barniz. Es decir, hoy hay religiosidad en cada rincón del mundo, hay una necesidad de respuestas, para las preguntas más basilares de la persona, pero, sin embargo, los barnices del cristianismo obstruyen penetrar la profundidad del misterio ${ }^{64}$.

Los dogmas, rituales, comunidades, etc. se han convertido en un freno para la experiencia fundamental de la Vida; hay una conciencia colectiva de que el misterio es algo presente y uniforme en la vida cotidiana, pero que ha sido reprimido por las ideas abstrusas del clero, en el mejor de los casos, sino pro el cristianismo en general. De este modo, la persona busca el goce de la vida, el sentido de la Pascua, que es una de las pocas cosas que se pueden aceptar de la religión, porque supone desenmascarar el peso de una cruz agonizante que la humanidad ha debido soportar sobre sus hombros sin saber por qué. En cierto modo, el anclaje español en el viernes santo, en la figura de una religión lúgubre y aniquilante, queda reflejado en el altísimo porcentaje de cristos crucificados que nuestro arte representa frente a los poquísimos resucitados.

No queda escapatoria, el cristianismo enterró con sus fórmulas y creencias un dios vivo, un Dionisio exuberante, un Baco explosivo, un Prometeo emancipado y desafiante. Tuvo la fuerza para doblegarlos, pero jamás los venció, siempre han estado aletargados hasta que las circunstancias han permitido que resurjan. Ha sido una larga espera, pero el renacimiento ha valido la pena, porque han elegido el momento oportuno, para hacer más daño y ser más efectivos. El cristianismo sólo es aceptado parcialmente en la medida que cumple este papel, ofreciendo posibilidades reales del deleite de la Vida. Toda manifestación que lo trunque será tenida como sospechosa, sino desdeñada de principio.

\footnotetext{
la Vida, es decir, para el desarrollo de las fuerzas de la naturaleza humana, desde las más elevadas hasta las más bajas".

62 Aparte de esa idea de contención del ritmo vital se debe considerar que se desconfía de todo lo que suene a tradición, precisamente porque ha sido uno de los factores que lo ha sofocado, $C f$. Torres QueIRUgA, A., Fin del..., 91-93.

63 La idea atraviesa el libro que cito de SÁNCHEZ NogALES, J.L., comenzando por el propio título La nostalgia del eterno. La idea base es que el hombre, como animal religioso, ha buscado desde siempre y de diversas maneras al trascendente, por eso lo desea, lo anhela y lo busca, sobre todo si ha habido un sistema que, en vez de ayudar a una anagnórisis, ha servido para enmascararlo y bloquearlo.

64 Cf. SÁNCHEz NogALES, J.L., La nostalgia.., 355-356, sobre lo que él llama "la nueva religiosidad es un supermercado espiritual, una city religion.
} 


\section{La Naturaleza, madre de la Vida y Vida misma}

Deben ser las fuerzas impersonales, el cosmos mismo, los que se mantengan por sí mismos, los que no necesiten de un dios personal. Todos formamos parte de la naturaleza, somos expresión de ella, es como una especie de cuerpo místico, donde nos fundimos y del que surgimos. Estamos acostumbrados a escuchar las ideas sincretistas sobre la existencia de fuerzas cósmicas que son las que provocan la armonía universal, aunque no se puedan percibir. Estamos ante una concepción de misterio muy vaga, muy general, muy imprecisa, pero por ello todos podemos pertenecer a él, sin exclusiones, sin limitaciones 65 .

Una concepción de la Naturaleza como organismo vivo, como madre de la vida, como prolongación de la Vida es el escenario adecuado para poder usufructuar la plenitud de los dones de la persona sin límites. Como consecuencia tenemos lo anteriormente dicho sobre la celebración de la Vida, sobre la búsqueda del placer personal, porque es la "única salvación" posible. Ciertamente delante a esta concepción tan genérica y neutra de la Naturaleza y el Misterio extraemos como positivo esa tendencia hacia la armonía universal, esa permisividad y acceso al misterio común que se aleja de la selección y exclusividad del cristianismo, aunque, por otra parte, la accesibilidad común se hace tan vaga y manejable que se suele convertir una prolongación y construcción de la persona, negando el principio contrario de representar la prolongación de la Naturaleza.

La concepción de la Naturaleza como marco de lo sagrado lleva a la vivencia de la exaltación de la naturaleza, de la celebración de la Vida en sus más altas posibilidades, porque el surgir y la pervivencia se juegan en ella ${ }^{66}$. Nos conservamos en la Naturaleza, vamos fundiéndonos unos con otros, mientras vivimos y más allá de la vida, porque, en efecto, sólo existe la Vida-Naturaleza en una forma dinámica expansiva de la que nosotros somos sólo apéndices, prolongaciones, por lo que pervivimos en ella ${ }^{67}$.

65 Para una visión general de las características de la nueva religiosidad $C f$. SÁNCHEZ NogAles, J.L., La nostalgia..., 336-356; Bueno de lA Fuente, E., España..., 252-253.

66 BUENO DE LA FUENTE, E., España..., 246: "La Naturaleza está dominada por espíritus y fuerzas que son las que las animan y unen en un único cuerpo a todo lo que existe. Esto es lo divino y lo sagrado: algo que no podemos dominar ni controlar y que por el contrario envuelve, penetra y alienta a cada uno de los seres".

67 Bueno DE LA FuENTE, E., España..., 246: " La Naturaleza es concebida como un organismo vivo, que se basta a sí mismo y que en este sentido es eterno. Por tanto se excluye la idea de creación, que supone a un Dios (personal) que contrapone al mundo, a la naturaleza. La única divinidad posible es la fuerza y la energía de la Naturaleza". 
Por tanto el papel que juega el Yo en la Vida es ser fiel reflejo de su esencia: Vida en eclosión. La estetización del cuerpo, la búsqueda del placer, el culto a la salud son exigencias de una sacralidad que se vive como una constante expansión del don de la vida. Hay que corresponder sin límites, buscando nuestra contribución a esa armonía; a mayor obtención de la plenitud vital entendida en este modo, mayor expansión, riqueza y plenitud cósmica.

\section{Politeísmo a la fuerza}

Muchos otros rasgos se podrían incorporar, pero para nuestro desarrollo quedarían condensados los fundamentales, de los que los otros serían una consecuencia o derivación, pero, para concluir con este análisis, creo conveniente subrayar otro aspecto fundamental con el que nos encontramos en la experiencia religiosa de hoy: un politeísmo creciente ${ }^{68}$.

Efectivamente no puede ser sino una consecuencia lógica del núcleo apenas expuesto. Una concepción de un misterio tan trascendente, difuso, general que se funde o manifiesta como fuerzas cósmicas armónicas en la Naturaleza, prolongándose en las vidas concretas debe concluir por fuerza en la negación de un único dios y por descontado un dios personal. La Naturaleza se ha convertido de nuevo en el marco o escenario por el que los dioses paganos vuelven a pasear. Espiritismos, gurús, adivinadores, horóscopos, supersticiones... forman parte de un bagaje religioso donde todo vale. Debemos concluir por fuerza que el religioso, el misterio, el sacro está por todas partes, pero de forma difusa y confusa, aunque, por lo general parece no importar. Las personas no tienen un fundamento estable al que agarrarse, a veces se fían de espiritualidades destructivas; pero hay un sutil telón de fondo que hace rechazar a la persona todo lo que suene a estable, fijo, definitivo, absoluto. Hay una desconfianza en el rostro concreto de Dios por el daño que ha causado y por la incapacidad que hoy día ofrece, para llevar a una emancipación de vida, a una plenitud de las posibilidades de vivir69.

68 Cf. Bueno de la Fuente, E., España..., 165-177 donde se nos ofrece un recorrido de varias características típicas de esta religiosidad neopagana como el predominio de la fiesta, la fascinación por la noche, el consumo, el buen vivir, nacionalismos y deporte, nuevo esoterismo, usos lingüísticos... $c f$. nota 42.

69 Como afirma Mardones, para los jóvenes españoles el cristianismo es "un añadido extrínseco, ajeno a nuestra vida, apto quizá, a lo sumo, para combatir malamente el frío... Una religión extrinsecista, hecha de obligaciones, cumplimientos, normas, leyes..., sin aliento interno. Una cultura religiosa para celebrar las Navidades, los funerales o los bautizos... Una religión de las cuatro estaciones y de las cuatro ceremonias de la vida, pero con casi ningún eco interior y personal”, MARDONES, J.M., ¿Adónde..., 45. 
No cabe otra solución; aun estando lejos en España de una generalidad creyente politeísta, sí que se ve una incipiente tendencia ya no sólo de los más jóvenes a esta apertura al misterio lejano, al sacro anónimo, a la admisión de divinidades vagas y en concomitancia, a la existencia del panteón de los dioses, a la reencarnación. Parece que Zeus ha comenzado a engrasar las bisagras de su panteón.

\section{A.4 La lógica del neopaganismo}

\section{El mecanismo pragmático-social del mito}

En esta corriente de recuperación del mito, se pueden dar sobre todo dos lecturas: pragmática y sociológica, porque ayuda a sostener el peso de la vida, modificando los procesos de la realidad y su conocimiento, así como a justificar el orden personal-social. Tanto en esta lectura pragmática como en la sociológica, que siempre vienen juntas, la mitología pretende recuperar el nexo de unión entre mito y razón en una crisis de sentido. Presentaré a continuación cuatro grandes autores que nos ayudarán a comprender la lógica del mito, de la religiosidad pagana.

Frank, que afirma que el mito expresa una nueva pregunta socio-cultural de la contemporaneidad y no de forma privada, como necesidad o deseo del sujeto, sino como exigencia de la sociedad, universal, lo que implica que podría fundar una estructura social por su función sacramental, al convertirse en un signo de un modo de poder vivir. No obstante es una clase de signo no legitimante en sí, porque el sentido, el valor le viene atribuido por los sujetos de un grupo. El mito así, en apariencia da un fin a la vida, inserta una teleología, al producir una gratificación inmediata, reconociendo incluso la necesidad de que tal gratificación sea institucionalizada. De este modo, el mito sirve para esta compensación inmediata, al hacer más soportable la tragedia vital. Obviamente por esta razón se corre el riesgo de la evasión de la realidad, de no hacerla frente, pero también resulta un proceso pedagógico, porque enseña a regular nuestra capacidad de reacción. Por lo tanto en este contexto, el Dios que debe venir es el que te capacita a realizar tu sueño existencial, porque te ofrece la posibilidad de realizarte como dios. El peligro servido por este esquema es que se olvida del sentido trágico de la vida, sólo puede entrar el dios victorioso, compensador, la divinidad analgésica, que, precisamente ese misterio tan lejano provoca ${ }^{70}$.

70 FRANK, M., Il Dio a venire. Lezione sulla Nuova Mitologia, Torino 1994, X, 96, "L'idea di un mito "privato" sarebbe contraddittoria come quella di una lingua privata [..] 
Blumenberg dirá que el mito es una manera de vivir y reaccionar ante el absolutismo de la realidad, a su prepotencia, al deber ser que ella impone. Permite al hombre superar ciertas preguntas, aunque, a su vez, pone otras. Delante a una realidad que no te mira, el mito ayuda a tomar distancia, a respirar, a crear otra dimensión espacio-temporal, por lo que el mito en este caso también ayuda a aligerar la vida, al ofrecer otras explicaciones de la realidad diferentes de la razón, organizado la vida de otra manera, conquistando cierta estabilidad que la realidad y su explicación por la razón no dan. El mito sería un equilibrio entre el principio del placer y la razón. Vemos de nuevo la doble cara, ya que ciertamente la religiosidad pagana permite una nueva forma de conocimiento, aunque son sus límites ${ }^{71}$.

Marquard parte del principio de que el mito es la expresión del abandono de los principios como fundamento de lo real, con lo que trasluce un modo de vivir escéptico. La historia no tiene principios en los que confiar, la vida no tiene orientaciones precisas y, por esto, se debe adaptar con pequeños recursos-criterios ${ }^{72}$. Como común denominador del mito, encon-

Il mito fonda e legittima un ordine sociale mediante discorsi che, ridotti alla loro pura funzione segnica, non hanno in sè nulla di legittimante, ma che ricevono questa funzione dai soggetti sociali in virtù di un'attribuzione di valore. Tutti i miti producono un'apparenza di ordine e forniscono una giustificazione teleologica della vita sia agli individui che ai gruppi, offrendo una gratificazione istituzionalizzata ai bisogni riconosciuti da una certa cultura. Il mito è la solida cittadella o, come dice Hegel, lèasilo sicuro la cui certezza simbolica rende sopportabile la tragicità del conflitti intersoggettivi e la precarietà delle iniziative e dei rapporti umani".

71 BLUMENBERG, H., Elaborazione del mito, Bologna 1991, 340, "il mito mostra l'umanità impegnata nell'elaborazione di qualcosa che la incalza, che la mantiene in uno stato di inquietudine e di agitazione, e che può essere espresso con la formula che il mondo non è trasparente per gli uomini e che essi non lo sono neppure a se stessi. Ciò non vulo dire ancora che la spiegazione dei fenomeni sia stata da sempre il fatto prioritario, e che i miti. siano stati qualcosa come degli espedienti che rimediano all'assenza di una teoria. Se i miti fossero espressione della mancanza di sapere scientifico o di una spiegazione prescientifica, sarebbero dovuto sparire da sè al più tardi nel momento in cui la scienza entrò nella fase della sua produttività crescente. Ciò che è successo è il contrario".

72 Es digna de tener en cuenta la observación que hace G. Faus sobre el fracaso de los grandes metarrelatos que anunció Lyotard. Si bien hay una desconfianza de las grandes metafísicas, él propone que existen grandes explicaciones de la existencia que, precisamente, corresponden con la manifestación neopagana. Así, ante los grandes límites de la vida, no se dan explicaciones metafísicas ni se cae en la desaparición del ser, sino en el recurso a los metarrelatos paganos como puede ser el fútbol: (ante el tsunami asiático del 26-D de 2005 y la afectación siempre a los más pobres) “¿Es debido tan sólo a que ellos no han sabido progresar? ¿O es más bien una consecuencia de la manera en que hemos progresado nosotros? He aquí una sugerencia para encarar estas preguntas: cuando los atentados del 11-S, todas las competiciones futbolísticas europeas suspendieron la jornada de liga de un domingo, en solidaridad con las víctimas de aquella barbarie (¿y de qué sirvió si no a nues- 
tramos la finalidad de compensación, vivida en este marco del final de los principios. ¿Cuál sería el matiz específico del mito según Marquard? Esta debacle de los principios quiere decir que la existencia misma debe hacer surgir los fundamentos, combatiendo de este modo el monoteísmo de los principios, todo lo que pudiera excluir la pluralidad, cualquier cosa que pudiera bloquear la existencia. Es fácil deducir que en este contexto el yo es el único punto de referencia, dejando a Dios de lado, sin entenderlo como egocentrismo, sino como el lógico sentido de la vida. La finitud del hombre se transforma en el trascendental de hoy, así se pude vivir sin límites, porque el mito da libertad al individuo, puede vivir como quiera; precisamente su eficacia radica en dar "determinaciones" a la vida, y cuantas más mejor; surge también el fenómeno de la personalización gracias a esta abundancia de posibilidades, de puntos de referencia para encontrarse a gusto. Obviamente esto comporta una visión del mundo inestable, una extrañeza del mundo y, en este sentido, el mito surge para equilibrarla, manifestando que precisamente la pluralidad sirve para organizar la vida, que la diversidad de elecciones no está en oposición. Estirando el esquema, cosa frecuente en la vida real, concluimos que no hay ningún problema en cambiar de apuesta radical, porque no se contradicen. Aứn más, como he expuesto antes, resurge el sentimiento postmoderno de la indiferencia, es decir, si nada está en oposición, todo puede ser cambiado radicalmente sin problema, no hay ningún criterio para diferenciar las manifestaciones de la realidad, para jerarquizarlas ni evaluarlas. Así, pasamos del llanto a la risa, de la corrupción a la honestidad sin ser capaces de percibir, analizar, concluir... Pero el triunfo en este caso es el logro de permitir no envejecer las experiencias, la pluralidad, de promover el crecimiento del desarrollo del individuo ${ }^{73}$.

tra conciencia y a no cuestionar el sistema?...este comentario es mío). ¿Haremos ahora lo mismo (¡y más!) por las víctimas del 26-D? ¿ O es que nuestra tan cacareada solidaridad con las víctimas del 2001 no era más que una adulación al imperio? Entonces todos éramos norteamericanos": GonZÁlEZ FAUS, J.I., Calidad, 161. En definitiva no deja de ser una opción por la cosmética que no quiere encarar, comprometerse y profetizar una cosmoética; como dice el autor, el problema ya no es si Dios existe o no, o si tal metafísica es válida o no, sino dar respuesta a qué debemos hacer y qué vamos a hacer.

73 Marquard, O., Apología del caso, Bologna 1991, 17-36, "L'uomo debe esistere in modo contingente $\mathrm{e}$ in base alle contingenze, contingenze però che per lui [...] non costituiscono opzioni eleggibili a piacere, bensì (formando quella scelta che egli è) destini incontrollabili, ai quali non si può sfuggire [...] Per questo si può dire che non si può vivere senza i miti: narrare necesse est. La perorazione di un politeismo disincantato e di una polimiticità disincantata è richiesta di libertà degli individui nella organizzazione dell'esistenza, la cui efficacia non proviene da una determinazione zero deo principi normativi, ma da una "abbondanza di determinanti". 
Kolakowski por su parte subraya la idea de que el mito es una reacción a la necesidad metafísica de la respuesta, es decir que le hombre siempre busca valores, pero antes lo hacía desde presupuestos metafísicos, sin atender tanto a las exigencias de la vida, a la realidad. Así, se deben encontrar respuestas inmediatas, derivadas de la misma e inmediata experiencia $o$, en otras palabras, para satisfacer las necesidades vitales. De este modo se padece una especie de horror metafísico, orientándose hacia el hinc et nunc (la televisión como referente institucional del que fiarse; psicólogos). Además el mito en este caso nos ayudaría más bien a deconstruir, para comprender nuestra existencia, pero no trata de explicarla, no tiene una propuesta. De alguna manera con este retorno neomítico en general se busca la compensación ante los grandes modelos metafísicosteológicos, así como una deconstrucción en el sentido que se asume el pasado pero invertido, cambiado, reorientado ${ }^{74}$.

\section{Límites de esta lógica}

Aunque sea legítimo reconocer la respuesta fresca que da al hombre, la posibilidad de una experiencia religiosa renovada, la capacidad de una nueva forma de conocimiento, los medios para vivir con mayor vigor la vida, debemos hacer una primera crítica que después, en el desarrollo de la tesis se explicitará.

Creo que queda claro que la concepción y creencia en un dios difuso, un misterio anónimo expresa los siguientes límites:

i. El sacro existencial común es tan común que todos lo intuimos, pero nadie le pone rostro o, mejor dicho, al ser tan absoluto es violado por todos. Al final hay tantos dioses, cuantas personas, sino más, pues, en definitiva, acaba siendo una construcción filosófica, proyección de la persona y expresión de sus exigencias, que, en el peor de los casos conlleva una ética injusta.

ii. Como consecuencia, el objetivo fundamental de esta religiosidad es reestablecer mi realidad, como la de la sociedad sin ponerla en cuestión; esta religiosidad, por principio, no puede tener un elemento profético denunciante, ya que lo que busca es el confort vital

74 Kolakowski, L., Presenza del mito, Bologna 1992, 96, "Il mito non ha fondamenti, non ne ha bisogno, ma non perchè non ne possa avere, al contrario: non ne può avere, perchè non ha bisogno di alcun fondamento. Quando ci rivolgiamo al mito, allora non andiamo alla ricerca di informazioni, ma ci situiamo in un luogo relativo all'ambito che esperiamo come la condizione (non logica, ma esistenziale) della nostra adesione al mondo e alla comunità umana, al terreno su cui i valori maturano e appassiscono". 
de la la persona. Nietzsche afirmó que el cristianismo era el opio del pueblo. Yo, en cambio, asevero que el paganismo, la nueva religiosidad es un analgésico barato.

iii. Como explicitación de la primera consecuencia, el neopaganismo permite una religiosidad que se vive a nivel individual (que no personal-personalizado), compartiendo con muchas tendencias políticas la concepción de la religión a nivel privado. Efec-tivamente sea la tendenciosidad política o la ignorancia social, buscan una religión que no moleste, que me haga estar bien para no hacer saltar el sistema. La falta de una dimensión profética o, al menos, pública en una religión hace que se convierta en un coladero de injusticias y de éticas deshumanizante, mientras que a mí me garantice mi confort.

\section{A.5 Dionisio y Prometeo retornan en una calígine}

Aunque se esté apuntando a una visión generalizada de la religión pagana, he querido seleccionar dos de las divinidades que serían el emblema de esta expresión vital de hoy día. Como ya queda dicho, Dionisio ${ }^{75}$, es el dios de una religión pasional desbordante, el adalid de la fertilidad, de la vida, de la fiesta, el estándar de la emancipación de todo gran relato que impide a la persona ser persona. He aquí que se cruza con la otra deidad, Prometeo, en su afán de emancipación, de independencia, de capacidad creativo-hermenéutica para trasformarse en auto-referencia, principio absoluto. De alguna manera podríamos afirmar que, sobre todo, la juventud española vive una religiosidad prometeico-dionisíaca, en el sentido que busca, a través de una razón renovada con el mito y la hermenéutica, su emancipación y su identidad en una calígine vital, donde no hay fundamentos absolutos, donde el principio unificador es encontrar la profundidad de la vida, entendida como un renovado y explosivo carpe diem o collige virgo rosas, antes de que la vida se marchite y ya no haya tiempo para la fusión con el placer ${ }^{76}$.

75 Cf. BUENo dE LA Fuente; E., España..., 263-283.

76 MARDONES, J.M., Postmodernidad..., 89-90: "Por tanto, se interroga al cristianismo como relato universal, y como relato universal ligado al proyecto de la modernidad. Dicho en forma de preguntas: ¿tiene que ser necesariamente el cristianismo una teoría universal de la realidad y de la historia? ¿Y tiene que estar vinculado necesariamente a un proyecto determinado de hombre y de sociedad: el moderno y -como no pocos neoconservadores propugnan hoy- capitalista?". 


\section{Las divinidades más presentes en escena}

Aunque, resumiendo, el denominador común del neopaganismo está ya explicitado, me gustaría subrayar alguna divinidad clásica, muy brevemente, para mostrar que estamos en tiempos muy parecidos a los que vivía Jesús de Nazaret. Efectivamente, la experiencia religiosa de los tiempos de Jesús era una del panteón de los dioses paganos, una teología trascendente, mágica y misteriosa que manipulaba y jugaba con los hombres a capricho. En nuestra segunda parte, Propondremos precisamente que Jesucristo se opuso precisamente a ese tipo de misterio sacro trascendente y lejano, alejado de la creación, pero "manipulable" en los sacrificios; incluso podremos ver cómo una de las críticas al judaísmo, precisamente fue ese vestigio que aún permanece (y que el cristianismo siempre ha compartido hasta nuestros días) del paganismo, es decir, la concepción de un mesías potente; en otras palabras, una divinidad totaliter alter, que por su condición divina hiciera justicia con su pueblo... en definitiva, una divinidad pagana con un barniz más personal, pero que recuerda al "dios con brazo poderoso" de todas las religiones desde la presencia entre los hombres y los héroes en la Odisea o la Ilíada hasta el Antiguo Testamento ${ }^{77}$.

Nos encontramos entonces en escena con las mismas divinidades que entonces, o sea con el mismo estilo de vida que aquéllas implicaban. En definitiva, el neopaganismo aquello que legitima es la capacidad de construir una divinidad tan individualizada que me satisfaga, me capacite para explotar la riqueza de la Vida y me dé resortes para reestabilizar el sistema, cuando falle. Hablar de un rostro de un dios o de otro de tan enorme panteón sólo nos recuerda que, el mito, desde el inicio de la humanidad ha servido para intuir la riqueza y la complejidad de la vida y ofrecer una respuesta concreta ante sus dificultades.

Aparte de nuestro protagonista principal y adlátere ${ }^{78}$, mencionaría a Adonis y el relato de Ovidio, Las metamorfosis ${ }^{79}$. De alguna manera no

\footnotetext{
77 Es curioso cómo en el panteón pagano, los dioses se pasean entre los hombres, pero sin tener nada que ver con ellos, sólo para ser sujetos a pruebas o burlas, también a favores, pero siendo siempre dos mundos diferentes; basta recordar el recorrido de Odiseo entre Eolo, Poseidón, Heleo, el propio Zeus, para ver el perfil de la divinidad potente con todas las posibilidades de manipular a las criaturas-creación.

78 "Dionisio" en Persson Nilsson, M., en Hammond, N.G.L. y Scullard, H.H., Dizionario di Antichità classiche, Milano 19952, 683: "Dionisio, dio di una religione passionale assai più che del vino... (durante il rito a Dionisio)vagavano sulle montagne intrecciando danze e brandendo tirsi e torce; al culmine della loro estasi prendevano un animale o addirittura un bambino, a seconda dei miti, lo dilaniavano e ne mangiavano le membra sanguinanti".

79 Cf. Metamorfosis (de Publius Ovidius Naso), Introducción, textos y comentario de Julio Campos, Madrid 1970. Como se intenta mostrar, la confluencia de diversas divinida-
} 
dejan de ser matices de lo ya expuesto. Adonis como el ínclito representante de la apuesta por la belleza humana, el culto al cuerpo, con su obligado cuidado y atención. El reflejo del fitness corporal se ve también en una religiosidad del fitness, donde las prácticas que se hacen son para encontrar una apariencia esbelta, que me ponga en forma interiormente. La conclusión es la misma: una estetización de la realidad, un embellecimiento pasajero externo-interno, pero que me hace sentir bien. El adonis de este siglo se perfila como un gran ascético por la consecución de las máximas posibilidades corporales, sumado a unas prácticas ligeras pseudo-religiosas (zen, yoga, relajación, psicología...) para intentar de encontrar una cierta armonía personal y universal: la belleza y la paz interior son la profundidad de la vida ${ }^{80}$.

Por otro lado las metamorfosis suponen el gozo por el cambio, por la mutación, la capacidad camaleónica de trasformación ${ }^{81}$. El cuerpo se convierte en objeto no sólo de ascesis, sino de todo tipo de castigos, para conseguir enmascararse. He aquí otro tipo de "cuaresma" o "penitencia", por la que los jóvenes invierten dinero, horas y sacrificios personales sólo por poder mostrarse con otro aspecto, con otra imagen a costa de cualquier precio. Se intenta obtener una capacidad divina de aparecer bajo diferentes rostros, de "revelar" diversas facetas, que, casi siempre paradójicamente suponen un velo, una máscara que oculta, porque sólo se busca la estetización de la belleza, pero ahogando la profundidad de la existencia. Basta ver a los jóvenes un viernes en clase y volverlos a ver horas más tarde en sus zonas de diversión, convirtiéndose, a veces, en irreconocibles. Peinados, maquillajes, piercings, tatuajes, rastas, complementos, confusión de usos y hábitos en el vestir (hoy la expresión ropa interior ya no tiene significado), el gusto por buscar el detalle que me haga diferente, sacrifican todo canon establecido ${ }^{82}$.

des en escena se entrecruzan, cada una con alguna peculiaridad, pero con el denominador común de la potencia dionisíaca, del gusto por la emancipación. De este modo, las metamorfosis se dan la mano con el Dionisio y con el Adonis, buscando el gusto por la estetización, por el poder del cambio, la liberación a través de la mutación.

80 "Adone" en Redding Walton, F., en Hammond, N.G.L. y Scullard, H.H., Dizionario..., 16-17: "Il bellissimo giovinetto ...Adone era una divinità della vegetazione $\mathrm{e}$ della fertilità”. El propio mito antiguo nos ofrece la ligazón entre la belleza, la estética y la fertilidad, poder de la naturaleza.

81 "Metamorfosi" en Jennings Rose, H., en Hammond, N.G.L. y Scullard, H.H., Dizionario..., 1350: "Nasceva così un mito eziologico. Si credeva anche asssai comunemente che i maghi avessero la facoltà di mutare l'aspetto proprio o altrui, ed è normale che un potere analogo venisse attribuito agli dèi".

$82 C f . G S 12$, que remite a la cita bíblica $G n 1,26$ sobre el hombre como imagen de Dios. Lógicamente la antropología bíblica, comenzando desde la condición corporal expresa la magnificencia de la persona como retrato, icono de Dios, que la nueva religiosidad es- 
Sólo queda resaltar el hecho mencionado en el subtítulo: esta "presencia divina pagana" acontece en una calígine, es decir en un momento de crisis de sentido, donde las personas son más objeto de la crisis que sujeto, más esclavos que dueños de la situación, más inconscientes que conscientes. Se vive en un modo sin saber qué está pasando exactamente. Posiblemente, en este punto sea ya más fácil entender la idea ya sugerida en el primer apartado, al hablar de los límites difusos de la experiencia religiosa; no sólo es que el cristianismo viva en concomitancia con el neopaganismo, como si fueran dos competidores definidos, sino que se vive también un "cristianismo pagano", donde los confines entre la identidad de una experiencia religiosa y otra no son nada claros.

\section{Signos concretos de esta religiosidad}

Ciertamente son muchas las manifestaciones que podrían exponerse, pero sería casi un filón inagotable; por otra parte, también se puede caer en el riesgo de ver neopaganismo por todas partes, como si no hubiera otro telón de fondo detrás de las experiencias de las personas. Yo me limitaré a sugerir algunos de los ejemplos que creo más significativos entre los jóvenes.

La experiencia del botellón enmarcado en un templo natural. Tal vez es uno de los mayores emblemas de las características expuestas: posibilidad de emancipación (aunque sea pasajera), trasformándose en dueño de sí mismo (a pesar de lo efímero y artificial), en un templo particular (lo más apropiado son los parques, es decir el contacto con la Naturaleza), donde se juntan todas las posibilidades para hacer explotar la Vida en unas horas (aunque se deba usar el alcohol o las drogas no supone una oposición), donde, aunque se tenga la capacidad de mayor autonomía, también se da la oportunidad de la relación, de la armonía con el grupo que te asegura (aunque sea una experiencia dependiente, inmadura, emocional), enmarcado en el misterio y magia de la noche, posibilitando aún más ese contacto con la Vida, porque es entonces, cuando el esplendor de la existencia y la seducción, el morbo cobran su máxima expresión ${ }^{83}$.

tética destruye; el cuerpo es más un objeto que enmascarar, velar, transformar... mientras que la Revelación cristiana nos recuerda el valor absoluto de la persona, iniciando por el cuerpo, como reflejo-revelación de Dios.

${ }^{83}$ Cf. Bueno DE LA FueNTE, E., España..., 89-92. "¿No puede ser considerada esta práctica colectiva como un verdadero culto a Dionisio, a través del más preciado de sus dones? ¿No es un modo de huida de la cotidianeidad que se desarrolla durante el día, que reglamenta la existencia a través del trabajo o del estudio? Cuando los jóvenes duermen de día y se divierten de noche, apoyándose en el grupo y en el alcohol, ¿no están buscando un 
El ya mencionado culto al cuerpo, llegando a límites obsesivos, cuando no enfermizos, se trasforma en otro eje vertebrador. La ausencia de moral como consecuencia viene de la mano; cuando el cuerpo y la búsqueda del placer se convierte en el criterio de actuación, no hay sitio para una opción fundamental, porque, precisamente ésta limita sus posibilidades, por tanto se razona en otro modo, de tal forma que aquéllos son el fin y no medios, justificando todas las acciones (léase) ética o moral en función de su crecimiento y desdeñando todo absolutismo que vaya en contra de ello. Si tenemos en cuanta todo lo expuesto, vemos que estamos en una encrucijada complicada, porque siempre es llover sobre mojado ${ }^{84}$.

Concluyendo este primer apartado se deja intuir que una religiosidad que se apoya en el embellecimiento de la realidad, que justifica toda ética en función de mi bienestar, siendo encima conscientes de que nuestra emancipación nos llega como seres hermenéuticos, porque toda gran ontología es imposible, hace imposible que un cristianismo repetitivo y con afán de absolutidad entre en una onda de propuesta. Delante al desafío del neopaganismo, hace falta no sólo este análisis de la realidad, sino también extenderlo al porqué falla como sistema religioso y llegar a reproponer algo diverso, si es que se es capaz. Al primer interrogante responderé al final de este capítulo, dejando la parte de propuesta, para el segundo ${ }^{85}$.

escenario distinto en el que puedan encontrar una plenitud de experiencias y sensaciones que les son negadas en el escenario de la vida moderna, la del progreso y de la producción? $[\ldots .$.$] ¿Qué valor hay que dar a estas manifestaciones típicas de los jóvenes?...Desde nuestro$ punto de vista ha de ser valorado más bien como un síntoma o una expresión de opciones más radicales y duraderas... El uso creciente de drogas que estimulan para adquirir sensaciones inéditas, el riesgo de subir a vehículos dirigidos por conductores embriagados, el vértigo de la velocidad incontrolada, la barbacoa con la que después de los exámenes se queman en la playa los libros y apuntes del curso recién finalizado... son síntomas diversos que apuntan en una dirección porque proceden de la misma raíz (91)".

84 MARDONES, J.M., ¿¿Adónde..., 39: "Nuestro momento actual conoce una multitud de formas de este culto de exaltación ritual y numinosa del cuerpo, que se explicita en la apoteosis de la cosmética, en la obsesión por estar en forma y en las diversas exaltaciones del cuerpo joven, de piel tersa y estirada, bien moldeado, perfumado, flexible, perfecto... Los gimnasios, el jogging, el aeróbic, la macrobiótica..., con sus rituales purificatorios y sus dietas sacramentales de proteínas, carbohidratos, calorías, etc., son sus manifestaciones piadosas... La sexualidad, con su misterioso acceso al placer y a lo profundo de la persona, del encuentro humano, del mito del andrógino realizado en la pareja perfecta, es otro de los santuarios donde se celebran más cultos y rituales... como recuerda $\mathrm{M}$. Eliade, resuena la nostalgia del paraíso perdido donde se consumara el encuentro edénico de los cuerpos sin malicia ni culpa".

85 El problema se agudiza cuando no se sabe con quien se debe dialogar; “¿Qué le ocurre al cristianismo en esta situación? Se encuentra mal equipado. Había adquirido el estatuto dialogante con el proyecto de la modernidad cuando los proyectos culturales soplaban ya en otra dirección. Está acostumbrado en el entrenamiento opositor y conflicti- 


\section{EL NIHILISMO DEL DIOS CRUCIFICADO, PARTÍCIPE DE LA NUEVA RELIGIOSIDAD}

\section{B.1 ¿Qué clase de nihilismo ${ }^{86}$ ?}

\section{El desencanto del postmoderno}

Un punto de partida sería iniciar con el manifiesto que nos sitúa en el origen de la reflexión sobre el término postmoderno, es decir con Lyotard que hace un estudio de los cambios sociales en Canadá hasta los 70 , donde afirma que la postmodernidad es una condición de la vida, una conciencia cultural que lleva a un cambio de la misma. Según Lyotard el inicio de este nuevo giro es la crisis de los fundamentos de las ciencias, como un modo de conocer que no es capaz de encontrar las bases de su propio conocimiento. Se trata de un paso del fenómeno al fundamento. Otra característica es el desarrollo de la nueva tecnología, pero entendida como una forma de aproximación a la existencia, donde el hombre expresa el sentido de la historia, su propia existencia, resulta un ethos del hombre como condición para comprender la vida ${ }^{87}$.

De este contexto del decline de las ciencias y nueva vivencia de la tecnología se derivan al menos tres grandes metanarraciones del postmoderno, llamadas así, porque han supuesto intentos fallidos de explicar la historia del mundo moderno 88 : a) La fábula de la emancipación de la humanidad

vo y en el recién estrenado de interlocutor, a tener objetos claros y distintos, sistemas: elpensamiento moderno, la política, la ciencia... Pero, cuando el interlocutor es el fragmento, nos quedamos sin objeto", MARDONES, J.M., Postmodernidad..., 154.

86 Acorde con el desarrollo del argumento, se propone un concepto de nihilismo que emerge en paralelo con el neopaganismo y que, a grandes líneas, significaría: "La lezione teorética del nichilismo asume l'ipotesi della transitività delle cose e della opzione di un senso plurale che non significa necesariamente mancanza di senso, ma proposta dell'assoluto relativismo e della serena tolleranza e rispettabilità. Il politeismo dei sensi dice mancanza di orientamento unico e, quindi, pluralismo dei modi di esistenza che disegna la forma dei valori-guida. Per questo, l'etica neopagana, quale etica del finito autosufficiente e misurato gnosticamente sulla certezza di sè, sembra incarnare l'epoca della indiffrenza postmoderna in una teoresi di piccolo cabotaggio e nella ineluttabilità della posthistoire", DOTOLO, c., "Secolarismo e nichilismo in Fides et ratio" en Fisichella, R. (a cura di), Fides et ratio. Lettera enciclica di Giovanni Paolo II, Edizioni San Paolo, Milano 1999, 271.

${ }^{87}$ LYOTARD, J.F., La condizione postmoderna. Rapporto sul sapere, Milano 1981.

88 Touraine, A., Critica della modernità, Milano 1997, 220-230, "Il postmodernismo, quale l'ho appena definito e quale mi accingo a descriverlo nei suoi principali orientamenti, è molto più che una moda intelletuale; esso prolunga direttamente la critica distruttrice del modello razionalizzatore sferrata da Marx, Nietzsche e Freud. Esso è il compimento di un lungo movimento intelletuale". NACCI, M, Postmoderno, in P. RossI (ed.), La filosofia IV, 388: "Infatti, il postmoderno non critica affatto la modernità, che sarebbe una darle credi- 
fue el gran tentativo del iluminismo, queriendo demostrar, explicar y vivir en consecuencia que el hombre puede liberarse de la inmadurez de la razón, del mundo de las creencias religiosas, pero la historia ha demostrado lo contrario; b) El idealismo y la teleología del espíritu que tiene en Hegel su máximo representante, sosteniendo que el espíritu humano se halla en un continuo desarrollo hasta que alcance su perfección y plenitud en la totalidad de la historia ${ }^{89}$; c) La hermenéutica del sentido lo que realmente descubre es que ya no hay un modelo-fundamento metafísico, surge la crisis de la objetividad, porque ya no se cree que se pueda llegar al objeto. Emerge así una subjetivización del proceso de conocimiento, tomando conciencia de que somos seres "interpretantes", según el mundo de nuestras precomprensiones. En consecuencia, la verdadera emancipación viene interpretando, sin la pretensión de conocer objetivamente el significado.

Según Lyotard la postmodernidad ${ }^{90}$ no desdeña estos tres fallos metanarrativos de la modernidad, sino que los trasforma, los purifica y asume lo mejor, afirmando al final que el modelo interpretativo no es ya ni metafísico ni teológico-religioso, sino subjetivo ${ }^{91}$ (el sentido para mí). La emancipación, el espíritu y la hermenéutica están presentes, pero sin referencia alguna a lo metafísico, religioso. Lo que importa es la hetero-

to, ma semplicemente ne spazza via le condizioni di esistenza, o almeno crede di farlo, all'interno -come abbiamo visto- di una definizione particolare di moderno. In realtà bisogna osservare che nelle polemiche sul postmoderno, il tertium non datur potrebbe essere attribuito proprio ai critici di questo movimento, e ai più accesi. Per loro, infatti, non c'è in realtà nessuna alternativa al moderno."

${ }^{89}$ Hegel, G.W.F., Fenomenologia dello Spirito, tr. it. a cura di V. Cicero, Milano 1995, 59-60, "D'altra parte, non è difficile scorgere come il nostro tempo sia un tempo di gestazione e di transizione verso una nuova epoca. Lo Spirito ha rotto i ponti con il precedente mondo della sua esistenza e delle sue rappresentazioni, ed è in procinto di sprofondarlo nel passato: vive il travaglio della propria transformazione [...] Solo che questo nuovo mondo, come il bambino appena nato, non ha ancora una realtà compiuta [...] Il primo sorgere è innanzitutto l'immediatezza, il concetto del nuovo".

90 LYOTARD, J.F., Il postmoderno spiegato ai bambini, Milano 1987, 91, manifiesta que el término no encierra una descripción literal, sino, como casi siempre, busca aproximarse a la definición de evento y así expresa: "il "post" di "postmoderno" non significa un movimento di come back, di flash back, di feed back, un movimento insomma di ripetizione, bensì un movimento in "ana-", un processo di analisi, di anamnesi, di anagogia, e di anamorfosi che elabora un "oblio iniziale". VAtTimo, G., La fine della modernità, Milano 1985, 9-23, "Le cose, però, cambiano se, come pare si debba riconoscere, il post-moderno si caratterizza non solo come novità rispetto al moderno, ma anche come dissoluzione della categoria del nuovo, come esperienza di "fine della storia", piuttosto che come presentarsi di uno stadio diverso, più progredito o regredito, non importa, dela storia stessa."

91 Cf. Dotolo, C., La teologia fondamentale davanti alle sfide del "pensiero debole" di $G$. Vattimo, Roma 1999, 55-57. 77-109. 
geneidad de sentidos y, así, si hay una verdad, serán tantas como selecciones de verdad posibles que pueda realizar el sujeto. La verdad es plural, porque hay una disolución del punto de vista y plurales son las posibilidades que el hombre tiene de vivir, por lo que adviene una disolución de la unidad, de cualquier solución que postule la convergencia.

Esta especie de incredulidad nos confronta con cualquier explicación que interprete lo real, reaccionando o tomando una de estas dos posturas: con un fundamentalismo, que supone un proceso contrario a un crecimiento, porque la multiplicidad bloquea ${ }^{92}$. En este caso, ante el temor de la disolución total de los valores pasados y fundamentos estables, se vive la radicalidad del anacronismo en el sentido de que, olvidando la evolución y fenómenos históricos, uno se ancla en un momento determinado del pasado con fundamentalismo, como si el intervalo entre ese tiempo y el actual no hubiera existido, afirmando además que aquello, tal y como se vive, es lo puro, es lo auténtico (pensemos en nuestros grupos religiosos que se basan en la radicalidad de un momento del cristianismo intentando vivirlo en su pureza originaria, siendo o no conscientes de que es una reacción contra el mundo plural, contra la diversidad hermenéutica); o bien con cierto fideísmo depositado en aquellas personas que pueden ser guías externos de la propia vida, permitiendo vivir tranquilamente la complejidad de la vida (esa multiplicidad de realidades interpretadas) como es el caso del gurú o, el gran referente universal, la televisión, principio fundamental del que fiarse. Es de advertir que sutilmente (como continuaré diciendo con casi todas las manifestaciones de la post-modernidad) este fideísmo se está convirtiendo en el hilo conductor de la vida política, económica. El mecanismo aquí es sencillo: dado que la pluralidad desorienta, fragmenta, incluso angustia, ante la imposibilidad de poder controlarla, se busca una guía que ordene esta crisis, poniendo una total confianza en ella, sin poner en cuestión los porqués de sus decisiones.

Yendo aún más allá con las consecuencias de la diversidad de realidades, de interpretaciones hallamos también la multiplicidad de las racionalidades no homogéneas, no iguales. Detrás de esto está la distinción aristotélica de la razón teórica, práctica y técnica. Es digno de mención por la terrible consecuencia que tiene en el hombre contemporáneo, que actúa diariamente bajo este condicionante que podríamos llamar el hombre

\footnotetext{
92 Nótese la conexión íntima con la religiosidad neopagana, ya que ante la dificultad de un mundo plural y sus problemas, el mito surge como una nueva intuición que sustituye a la religión y a la razón, para reaccionar cotidianamente de manera más creativa y eficaz.
} 
fragmentado. La cuestión es sencilla y, una vez más, velada: los niveles estéticos se pueden vivir sin coherencia alguna con los teóricos; se elige, decide, opta sin referencia a los principios, acabando en lo que podríamos llamar una dispersión de la razón entendiéndolas en su sentido amplio, donde los principios, valores, criterios, gustos, emociones... parecen que no tienen ya nada que ver entre sí; los modelos no coinciden ${ }^{93}$.

La persona postmoderna vive en consecuencia en un momento de desconfianza en los grandes relatos, fiándose de los pequeños recursos que puede encontrar cada día a través de la creatividad hermenéutica y de una religiosidad que se abre a la vida, así como depositando gran confianza en la mentalidad científica. El fracaso de las grandes propuestas de la humanidad ha llevado al postmoderno a vivir con cierto desencanto ante la vida, pero encontrando en la hermenéutica, el neopaganismo y la técnica, respuestas que sacian el deseo de sentido.

\section{La secularización, causa de este desencanto nihilista ${ }^{94}$}

Pero, ¿de dónde surge este vacío existencial? ¿Qué ha hecho desencadenar esta crisis? Sin duda, la modernidad ha portado una crisis de la Tradición, una crisis de cómo se ha vivido el cristianismo. Pero, precisamente, como argumentaré un poco más adelante, esta crisis ha aparecido como un proceso de secularización nacido de la perspectiva bíblica ${ }^{95}$. La secularización, lejos de ser un apéndice del cristianismo o una nueva etapa, ha supuesto una nueva estación en la comprensión de la vida ${ }^{96}$.

93 Cf. Dotolo, C., ibid., 392-394.

94 Como ya he indicado anteriormente, la tesis que planteo es aquella iniciada por los teólogos de la secularización iniciando con Gogarten, para el que la secularización no sería "un fenómeno scoperto da pensatori che aprono l'epoca del moderno e del post-moderno. Essa, come fruto dell'autentica fede cristiana, è invece presente fin dall'inizio della predicazione di Gesù Cristo. Ciò spiega perchè per Gogarten la secolarizzazione sia necessaria $\mathrm{e}$ legitima conseguenza della fede cristiana. L’autentiza fede cristiana non può essere quindi altro che fede secolarizzata", PENZO, G., Friedrich Gogarten, Brescia 2004, 122.

95 Esta perspectiva teológica implica aceptar que la esencia del cristianismo desde la mismísima predicación de Jesús se juega en dos vertientes: la desacralización y la mundanización, afirmando que estos dos fenómenos no han nacido ni después ni en contra del cristianismo, sino gracias a él. Para entender bien la perspectiva teológica de la mundanización se debe leer en el contexto de la doctrina de la creación y encarnación según $c f$. METZ, J.B., Sulla teologia del mondo, Brescia 1969, 11-51.

96 Dotolo, C., "Secolarismo...", 267-268: “E pensabile, allora, che la secolarizzazione rappresenti nel suo originario movimento un principo ermeneutico, suprattutto se da una teologia della secolarizzazione, si passa ad una teologia dalla secolarizzazione, la cui lettura supera un banalizzante costume interpretativo che identifica tout court secolarizzazione 
Efectivamente, emana de la propia esencia del cristianismo, es un producto de la reflexión bíblica cristiana. El sentido profundo de la Revelación, el principio de la kénosis, de la encarnación implica entrar en la historia y, por ello, negar la separación de lo profano y lo divino. Para los cristianos la vida humana no se divide en sacro y profano. Por tanto implica una transformación de la concepción de Dios, del hombre, de la religión, de la historia; lo sacro no es algo ajeno al mundo ni algo que bloquea o sustituye la madurez del hombre, sino que es una respuesta a la experiencia de sentido, porque la centralidad no es la religión, sino el hombre mismo, la vida, la historia concreta.

La Revelación pone en el centro la conciencia histórica, interpreta al hombre en su concreta humanidad. La historia es dramática ${ }^{97}$, es apertura y cierre, don y bloqueo, porque caminamos hacia una verdad más grande que nosotros ${ }^{98}$. La secularización de la religión, de lo sacro, de lo divino, de Dios conlleva a un modo de ser en el mundo, a un principio interpretativo y no a ser un simple método o apéndice.

Nos damos cuenta que la secularización es un principio interpretativo-hermenéutico, porque implica una cuestión del sentido que le pertenece. Cambia la visión de la relación de lo sacro con el hombre, donde el hombre no es ajeno a su historia ni a Dios. El kerigma se desarrolla en la

e desacralizzazione...La secolarizzazione, quindi, nella sua radice teologica porta con sè una dimensione nascosta di senso che svela la distanza da visioni del mondo non conigabili con la novità sconvolgente dell'evento cristiano. Essa mostra il passaggio da un mondo divinistico ad un mondo affidato alla responsabilità dell'uomo, in cui la fede è chiamata ad esprimere la sua forza profetica, soparttutto laddove la storia mostra i segni di una crescente disumanizzazione. La secolarizzazione, cioè, tiene aperta la tensione ineliminabile per la domanda su Dio, nella quale vive la stessa domanda antropologica, considerata sempre più mero anacronismo".

97 Aparte de la emblemática obra de Von Balthasar, Teodramática, son muchos los autores que se hacen eco de la visión dramática de la existencia y, por tanto, de la teología; basta esta pequeña consideración de Jünger Moltmann: "Il XX secolo non ha portato nel mondo nuove idee, visioni o utopie in grado di dare un senso alla storia. I cadaveri che si è lasciati dietro escludono ogni conferimento di senso ed ogni teodicea, ideologia del progresso, voglia di globalizzazione. Il progresso di questo secolo è disseminato di rovine e di vittime, e nessun futuro storico riuscirà mai a bonificare tante sofferenze, come nessun futuro migliore ci potrà mai assicurare che quelle sofferenze non sono staete vane...In ogni caso il XX secolo, confrontato con quello che lo ha preceduto, insegna almeno una cosa, che è impossibile portare a compimento la storia nella storia", MOLTMANN, J., "Il paso del Duemilla" in Gibellini, R., Prospettive teologiche per il xxi secolo, Brescia 2003, 39.

${ }^{98} \mathrm{DV} 8$ donde se recuerda que la Iglesia está en tensión hacia la Verdad, lo que implica que es un proceso siempre en dinamismo; $D H 1,2,11$ recuerda, por su parte, que aquel dinamismo es patrimonio de todo hombre por ser una vocación hecha desde Dios. 
historia y ésta nos ofrece los signos para interpretar y captar el sentido de nuestra existencia y nuestra relación con Dios ${ }^{99}$.

El problema, de frente a esta lectura positiva, es que esta frescura de la Revelación bíblica se ha oscurecido en su transmisión, llegando a la modernidad y a nuestros tiempos, cubierta bajo patrones metafísicos absolutos, obstruyendo el núcleo: la relación de Dios con el hombre, es decir, la secularización culmine en Jesucristo, un Dios para el hombre concreto, ha sido ontologizado por los cristianos. Por eso el sentido del Enmanuel se ha invertido, en vez de respirar el sentido profundo de un dios que ha identificado lo humano con lo divino, para favorecer el desarrollo de la historia, de cada hombre particular, ha significado a veces una deshistorización de Jesús, una ontologización de su mensaje... Jesús se ha quedado más en el nivel de la verdad que en el de la vida, en la metafísica que en la antropología100.

Por eso, muchos movimientos neopaganos culpan a la Revelación bíblica del desencanto creado por un dios que ha negado, ha truncado la vida $^{101}$. El postmoderno es un hereditario de un fracaso metafísico-religioso, que busca cualquier recurso para sobrevivir sin pesados patrones, porque se ha encontrado solo en el mundo ${ }^{102}$. Pero aún falta un pequeño análisis en nuestro recorrido, que expondré inmediatamente: nihilismo y neopaganismo van de la mano, porque la Revelación cristiana con dos de sus hitos, la creación de la nada y la muerte de Cristo, han llevado al postmoderno a este susodicho desencanto, precisamente, porque la religión pagana tenía una conexión con la Vida original; sin embargo la "Revelación ontologizada" nos ha llevado a ofrecer unos esquemas que han cortado esa conexión y, en consecuencia, la plenitud del hombre. No queda sino una confianza en esa armonía cósmica, en esa pervivencia eterna universal en su conexión con la potencia de la Vida103.

99 GS 76, AG 15, UR 4.

100 "En esta Revelación, Dios invisible, movido de amor, habla a los hombre como amigos, trata con ellos para invitarlos y recibirlos en su compañía", $D V 2$.

101 Habría que retornar a una consideración de la Revelación más humilde y viva, como sugiere Dotolo "verità che dona a pensare": "È questa la verità del cristianesimo: la prossimità di Dio all'uomo è lo spazio perchè l'uomo possa volgersi dal problema al mistero e ricercare la sua viera identità", DoToLo, C., "Secolarismo...", 274.

102 Idea repetida por los reconocidos existencialistas pesimistas Martin Heidegger (1889-1976), Karl Jaspers (1883-1969) y Jean-Paul Sartre (1905-1980).

103 Cf. MARdones, J.M., ¿Adónde..., 32. 
Una lectura de la contribución del cristianismo a la experiencia de la nada

No es la presunción de agotar un tema, sino más bien de presentar el contexto, la plataforma postmoderna en la que nos encontramos, ofreciendo alguna clave de lectura, para, en la segunda parte, desarrollar alguna intuición práctica como forma de actuación. Dicho esto partiré de la conciencia de que la idea de la nada se puede leer, en cualquier modo, como fruto de la modernidad cristiana y que ha entrado en el mundo para percibir la vida misma. En este caso, la decostrucción sería el éxito de la nada que interpreta los deseos de nuestro mundo. Brevemente diré los aspectos nucleares que creo que sean los puntos que desvelan los síntomas de una humanidad rodeada por una nueva experiencia de la nada ${ }^{104}$.

104 "Se ha llegado a la consumación del nihilismo, al sin sentido absoluto de la realidad, a la carencia de la validez de los valores supremos, y así nada es verdad ni nada está bien. "Dios muere" en la medida en que el saber ya no tiene necesidad de llegar a las causas últimas, en que el hombre ya no necesita creerse con un alma inmortal (...) La muerte de Dios produjo la muerte del hombre (...), la diferencia entre modernidad y la filosofía contemporánea está en que en esta última ya no hay subjetividad. El hombre es únicamente un elemento más de la estructura. Por ello, nuestra época es la era de la muerte del sujeto." Forment, E., Lecciones de Metafísica, (Madrid 1992) 45.Cf. MARDONES, J.M., Un debate sobre la sociedad actual: Modernidad y posmodernidad, RAZÓN Y FE 1.056 (1986) 207.

Para una visión general de estas notas del nihilismo positivista actual:

a. Hay un ofuscamiento de la inteligencia humana, que se halla colapsada en la búsqueda de una verdad plena que dé fundamento y sentido a la vida (cf. FR4). Además, al perderse el anhelo de la búsqueda del sentido, la existencia humana queda a merced de los sentimientos e impulsos irracionales, dominada por los instintos ciegos o por los diversos manipuladores, lo que lleva a la desintegración de la persona y de su entorno familiar.

b. Al hombre se le valora sobre todo como homo faber y su trabajo se mide en razón de la sola productividad.

c. El concepto de libertad queda reducido a la elección de cosas según el arbitrio personal, al margen de la verdad del hombre. Esto lleva a un nihilismo corrosivo que convierte a todo en válido, incluso los comportamientos destructivos (cf. FR5).

d. Las relaciones entre personas se convierte en un conflicto entre libertades y límites. Todo es posible con tal de no violentar la libertad ajena.

e. El ámbito público está marcado por una ética utilitaria, común denominador de los intereses individuales mayoritarios (cf. VS6).

f. Muchos contemporáneos nuestros están condenados a una terrible soledad y a una incapacidad para establecer vínculos profundos que fortalezcan su vida personal, como consecuencia del individualismo cultural dominante.

g. Otras rupturas de hondo calado que están repercutiendo fuertemente en el orden social y familiar son: la ruptura entre la sexualidad y el matrimonio, entre la sexualidad y la procreación, entre la sexualidad y el amor. Las consecuencias sociales de estas fracturas están a la vista de todos.

h. Como consecuencia de una libertad sexual sin límites, cualquier actividad sexual aparece como un "derecho". Así vemos que la manipulación del lenguaje lleva a presentar, 
La creación de la nada bíblica lleva consigo una convicción: el mundo no es necesario, es más la vida se entiende como inútil, pues todo está legado al libre arbitrio divino. Si todo proviene de la nada, entendemos que se transforma en una amenaza para el hombre, para toda existencia, porque la nada no tiene un fundamento seguro (el terror aún aumenta más ante los desastres naturales). La persona es el propio fundamento. La nada es la característica misma de la realidad, es el producto de un mundo que expresa la voluntad, pero también la distancia de quien lo ha creado. Efectivamente, según este nihilismo, podríamos afirmar con la teología que Dios es el totaliter alter, precisamente para afirmar su abandono como alteridad nihilista.

Pero esta creación de la nada comportaría otra idea aún más agónica; si el mundo es otra cosa diversa de Dios, si vive en la libertad de Dios, se concluye fácilmente que el mundo no es divino. Precisamente la libertad trascendente del Dios hebraico lleva a la desacralización del mundo. En consecuencia, de esta distancia puede nacer la idea de que el mundo puede ser rechazado, profanado, ya no tiene valor en sí. La paradoja de la creación sería que la distancia del Creador, del ser omnipotente hace a la creación inferior ontológicamente, porque no la habita. La idea del desprecio despierta también en el marco de esta extrañeza: ¿vale la pena el mundo y sus empeños? ¿Vale la pena participar, ser corresponsable ${ }^{105}$ ?

Esta vivencia de la ausencia de valor, de desacralización del mundo, ¿cómo se expresa? Con la dramaticidad de la experiencia del mal. Es la experiencia ontológica de un mundo que no parece ser el mejor ni tener fundamento. Con este discurso se ve ya asomar la consecuencia que comporta para el cristianismo. Para la religión cristiana el real produce un decremento existencial; el pecado original sería la idea de un empobreci-

con palabras "políticamente correctas", realidades éticamente rechazables: derecho a la anticoncepción, a la salud reproductiva, al libre diseño de la sexualidad, a la elección del llamado "modelo de familia" y su institucionalización, etc.

i. El materialismo de la cultura del vacío conduce a un desprestigio de la familia, a una desvalorización de la vida, y a considerar al anciano y al minusválido como una carga, no ya sólo familiar, sino incluso social.

j. La última consecuencia de este nihilismo cultural es la pérdida de esperanza, con el consiguiente miedo al futuro y, sobre todo, el pánico a la muerte, que se han convertido en tabúes en la vida ordinaria. De esta manera, la verdad del hombre queda restringida a lo que éste puede dominar y manipular.

105 Todo lo contrario a la idea de secularización proveniente de otra perspectiva de la creación y el evento Cristo. 
miento ontológico ${ }^{106}$. Sería por otra parte como el desafío del hombre a Dios, que quiere afirmar la capacidad de hacer otra creación, porque el proyecto de Dios no es compartido. El problema es que este decremento ontológico producido por el pecado, esta pérdida de la plenitud existencial es vivido en la historia como la incapacidad de recuperar tal estado precedente o, por mejor decir, originario. El mal, la limitación es el desafío diario contra Dios que parece no ser capaz de justificarse ante una espiral sin fin. Pero la peor consecuencia de la historia del pecado es que se concluye que la vida, la existencia o la creación es una parodia porque sólo es hipotética: precisamente lo que existe es su propia negación, o sea la creación revela la negación del ser, de la realidad. Habría que matizar que este nihilismo tendría una diferencia con el de la modernidad, porque no se afirma exactamente la culpabilidad de Dios ni la responsabilidad del hombre, sino que se vive la negación de la consistencia de la creación sin la esperanza en un futuro mejor ${ }^{107}$.

Quedaría un último punto de desarrollo de esta experiencia de la nada de nuestros días. ¿Dónde está su raíz? Lamentablemente la afirmación nos pone delante muchos interrogantes: en el cristianismo que ha insertado la nada, la inconsistencia del ser en la experiencia de la vida. Aún más, a la base de esta experiencia está la "piedra truncada": la muerte de Cristo como fracaso mayor de la creación, de Dios. El mundo ha matado a Dios y el intento de Cristo de renovar la creación ha fallado. Ha demostrado más bien que Dios puede ser negado, asesinado, rechazado sin grandes problemas. De este modo, la lectura más positiva que la humanidad puede hacer del evento Cristo no es la salvación como nueva creación-escatología, sino como invitación a contentarse-resignarse, porque no es posible eliminar el mal. De frente a la muerte el hombre puede coger el puesto de Dios o afirmar que el mundo no tiene sentido ${ }^{108}$.

Como conclusión de esta breve exposición sobre el nihilismo actual se aprecia como telón de fondo la gran paradoja del Dios cristiano. La inmanencia, la cercanía del Dios de Jesucristo ha creado, a su vez una

$106 \mathrm{He}$ aquí el punto crucial que ha ahogado el optimismo antropológico del paganismo; las respuestas ontológicas que se han hecho del cristianismo han olvidado esta dimensión del paganismo, que, por otra parte pertenece a la propia esencia de la Revelación. Cuando durante tiempo una religión ha asfixiado a la persona, a la Vida, ésta no puede sino emerger con toda su fuerza.

107 Cf. DOTOLO, C., La teologia, 203.

$108 C f$. BUENO DE LA FUENTE, E., España..., 266-268. 
mayor distancia ${ }^{109}$. El hombre no puede soportar el mundo solo, no es capaz de vivir la distancia de Dios y el peso de la creación, pero la inmanencia cristiana ha mostrado la incapacidad de Dios, si cabe una mayor distancia, porque en su intento de aproximación ha mostrado el fracaso y la inconsistencia de la creación. Y así el hombre vive la nada, el sin sentido con mayor angustia. Ahora estamos en condiciones de entender que hoy día en el 2005, las personas no confían más en la razón, ni en la ciencia, ni en la institución, pero sí en la compensación que pueden ofrecer los mitos y el retorno del religioso que se adecue a este paradigma.

\section{B.2 ¿Qué clase de religiosidad vive hoy el cristianismo dentro del ambiente neopagano-nihilista?}

Como consecuencia de todo este ambiente, nos hallamos delante a un cristianismo, si cabe decirlo, contaminado por estos procesos. Ha perdido bastante de su identidad y naufraga como puede, avanzando, desde mi punto de vista, de improviso. Los dos pilares gruesos de esta nueva vivencia religiosa-cristiana son la individualización del proceso religioso, del propio Cristo y el "detradicionalismo", entendiendo este neologismo como la vivencia de un cristianismo sin tradición, como si no hubiera existido, llevando a un mosaico de cristianismo tan concomitantes como ajenos los unos a los otros por su falta de identidad común.

La individualización quiere decir que cada uno se crea su religión según la necesidad de compensación que tiene. Si recordamos el planteamiento ya expuesto, la religiosidad del mito y del postmoderno en general es la de aquel hombre prometeico que, lejos de actuar según unas profundas convicciones y fe religiosas, lo hace para satisfacción personal y reajustar el esquema de la realidad, en definitiva, para no tener que sufrir el desorden de la vida, quitamos a Dios de en medio, para gestionar nuestras propias vidas, aunque con la sutileza de utilizar unas creencias en una divinidad tan genérica cuanto inalcanzable, que no cuestiona la vida y justifica mi status ${ }^{110}$.

109 Para una lectura diversa de cómo pensar la trascendencia del Dios cristiano: U. SONDERFELD, Pensare il "totalmente altro" in modo "totalmente altro"? Gli accenni "teo-filosofici” di Heidegger, in H. OTT-G. PENZO (edd.), Heidegger e la teologia, Brescia 1995, 197-205.

110 Cuando afirmo la idea de la concepción prometeica de la persona a lo largo de esta exposición, siempre es en referencia a la trasformación de la religión en una satisfacción personal donde el sujeto, la persona encuentra su autonomía. Según varios autores el problema de la crisis del cristianismo tiene que ver con el hecho de que nuestra religión sigue ofreciendo una imagen de un Dios que, al reconocerlo te priva este desafío de ser per- 
Pensemos en tantos jóvenes y no tan jóvenes que dicen creer en Jesús, pero no en la Iglesia, o que de Jesús sólo tomo aquello de la ayuda al necesitado, cuestionando su divinidad o tantos otros casos. Sin ánimo de criticar lo que pueden ser cuestionamiento muy dignos y justificados, el discurso que sí se comparte como denominador común es que con estas tan extendidas y "avaladas" aseveraciones no nos damos cuenta de que vivimos un cristianismo desencarnado. Si negamos ciertas realidades de Jesús y erradicamos la Iglesia del mundo, quitamos todo cuanto tiene el cristianismo de humano de raigambre mundana... porque además... ¿dónde queda siquiera el compromiso de aquéllos que desdicen del cristianismo? Así los sociólogos de la religión afirman sin lugar a duda que se vive un "creer sin pertenecer", algo que no se asume, ya que de frente a la individualización está la personalización, proceso que entra en la implicación de la vida, en la asunción, no en la perspectiva de la religión como herencia caída del cielo, sino en un desarrollo constante de interpretación, renovación y puesta en práctica de la tradición ${ }^{111}$.

Lo que he llamado "detradicionalismo" del cristianismo, apenas acaba de ser intuido; el cristianismo de hoy no parte de Jesús y menos de su Iglesia, sino de una especie de herencia anquilosada cultural ya carcomida y cubierta de polvo, de tal modo que la tradición ha pasado a perder toda su frescura; la Palabra que era vida ha pasado a ser encerrada en palabras muy lejanas de estar encarnadas o de, al menos, sugerir, orientar hacia aquella Palabra-Vida originaria; las eucaristías no son verdaderos memoriales, donde se actúa el único y originario banquete, sino que es una repetición, una mecanización ritual externa... en definitiva, la fuerza, el impulso, la vitalidad y vigor del Evento Originario ha perdido toda actualidad, porque ha sido transformado en un barniz cultural, la historicidad ha pasado a conocimiento, la Encarnación real en espiritualización eidética... La Tradición está condenada a muerte tanto cuando se convierte en repetición inmóvil como

sona, te limita, te reduce. MARTín VELASCO, J., Metamorfosis de lo sagrado y futuro del cristianismo, Santander 1998, 37-38: "El problema fundamental de las religiones en las sociedades modernas no es la crisis de determinadas mediaciones (Creencias, prácticas rituales, constelaciones simbólicas, organizaciones institucionales...), ni siquiera la presencia de ciertos comportamientos morales, aunque todo ello dé lugar a una serie de problemas que no se pueden olvidar. El problema decisivo, aquel entorno al cual se juegan el ser o no ser las religiones, es si es posible el reconocimiento de la absoluta Trascendencia, la adoración del único Dios, sin que el sujeto se vea condenado por ese reconocimiento a renunciar a su condición de sujeto, a su legítima autonomía, a su inviolable dignidad".

111 Cf. MARDONES, J.M., ¿Adónde va la religión? Cristianismo y religiosidad en nuestro tiempo, Sal Terrae, Santander 1996, 45-46. 
cuando llega al olvido o transformación absoluta; ahora, nuestro cristianismo, creyendo que vive campanadas de muerte, porque no entra en el sistema religioso, sin embargo no se ha diagnosticado el peor de los males: no es que sea una oferta obsoleta... es que ha perdido fidelidad porque ha roto bruscamente con sus raíces, con aquello que le da profundidad, autenticidad, vigor. El problema no está fuera, sino dentro, porque para dar fruto, hace falta podar y renovar lo externo, para ver un resurgir siempre nuevo, pero toda fachada por muy fuerte que sea, cae y muere si no tiene raíces, si no se riega. Para conectar con la religiosidad de hoy e interpelarla, debemos por fuerza tener raíces (sentirnos basados en la Sagrada Escritura y Tradición) y regarlas (hacer un esfuerzo por su renovada interpretación) o de otra forma, todo movimiento, toda idea, todo impulso de vanguardia con aires de desafío al mundo de hoy fracasará, porque le faltará la fidelidad a lo que distingue y da frescura al cristianismo de frente a los otros sistemas religiosos ${ }^{112}$.

Hemos hablado de dos cánceres que se cruzan en nuestra religión hoy, los cuales nos llevan a una vivencia cristiana que funciona con "códigos-criterios de préstamo", con una particular forma de expresión, que a su vez le ha llevado a una crisis. Veamos primero lo que podemos llamar unas dimensiones de la vida cristiana actual, para luego esgrimir alguna de las consecuencias de esta crisis.

La primera de las dimensiones del cristianismo débil es la comunitaria, donde, ante todo, se subraya la necesidad de los límites con lo otro, de los grupos. Es lo típico del adolescente, que necesita el respaldo de los otros para subsistir; mientras hay grupo hay fe, cuando desaparece viene la crisis o la nada. Así vemos multitud de jóvenes que tras la confirmación, desaparecen, porque su "fe" ha tenido el sentido, extensión y profundidad que la duración del grupo, del estar juntos. Lógicamente, la raigambre según este contexto se encuentra más bien en la identificación con el grupo que en la elección de un fundamento personalizado ${ }^{113}$. La dimensión ética que con-

112 El problema es que hoy se confunde, sin profundizar en las distinciones teológicas entre Tradición-tradición-tradiciones, el vigor de la raíz de toda tradición con las distintas formas pasadas del cristianismo; Torres QueIRUGA, A., Fin del cristianismo, 91-122, expone este problema calificándolo como "el fenómeno responde a una satisfacción generalizada, que busca llenar el vacío provocado por el abandono de la religión heredada, en unos casos, o por el descontento de sus formas establecidas, en otros (p. 92).

113 Se verá que la terminología utilizada para las distintas dimensiones es ambivalente, ya que son características que, siendo positivas y necesarias, si se radicalizan o se malinterpretan, llevan al cristianismo a otro extremo extraño a sí mismo. Así aviso al lector que la lectura de las mismas tiene que ser leída en esta clave, sin querer decir que tales dimensiones sean en sí contrarias a nuestra religión. 
siste en la aceptación de los valores del grupo que da la identidad. Como es lógico, esta cualidad no es para nada negativa, ya que también es fácil caer en la espiritualización angélica del cristianismo, pero el problema emerge, cuando los valores compartidos se basan en una especie de adquisición de una especie de garantía para la conciencia, un patrón de actuación que no nace de una convicción, de una opción fundamental, sino de la búsqueda de una compensación personal a través de acciones respaldadas por un grupúsculo; es decir, la ética no es tal, porque no se enraíza en una decisión personal, de hecho se acepta, sin necesidad de pertenecer propiamente al cristianismo, sin una maduración personal. La dimensión cultural lejos de responder a las exigencias de Pablo VI, cuando decía que la fe si no se transforma en cultura está vacía, consiste en comprender lo religioso como un bien cultural común, una experiencia religiosa que garantice la convivencia, una religión que debe someterse a los límites del orden común. Por último, lo que podemos llamar una dimensión emocional que nos conduce a una comprensión de la necesidad religiosa como vivencia gratificante, moviéndose en las ondas de la afectividad, del entusiasmo.

Con este panorama, se entiende pronto que este cristianismo ligero por una parte responde a la necesidad de compensación ${ }^{114}$ que, de alguna manera todos necesitamos, pero al mismo tiempo constituye desde el inicio el fin de la experiencia religiosa y, para situarnos ante la generalidad, cotidianeidad y evidencia del caso, propongo un ejemplo: las procesiones. Éstas comienzan por la identificación externa con las personas que pertenecen, siendo el estímulo de incorporación prioritario (comunitaria), que a su vez exige una ética de comportamiento, se es consciente de que implica una serie de valores religiosos que la gente acepta, no tanto por la asunción madura de los mismos, cuanto por su validez en sí en la medida que me satisfagan (ética), que a su vez garantiza una convivencia, expresa unos valores externos comunes, aunque para nada cuestionan la vida, sino que reestabiliza nuestro sistema (cultural), siendo a la vez un vehículo

114 Valga el siguiente fragmento, aunque el capítulo donde se encuentra no tenga desperdicio, para ilustrar el tipo de cristianismo que vivimos: MARDONES, J.M., ¿Adónde va la religión?, 34-35: "Una religiosidad que pone el énfasis en el individuo. La persona concreta, con sus gustos y su capacidad de elección, sería la que elige y determina el tipo de religiosidad. Una religiosidad que pasa por la experiencia afectiva. Vale lo que se experimenta; lo sagrado, lo religioso, se valida si se pasa el "test" de la experiencia personal, afectiva, emocional. Dará lugar a grupos y comunidades emocionales. Una religiosidad que ofrece la salvación "aquí y ahora" y que se ha de experimentar mediante la integración personal, el bienestar corporal, psíquico y espiritual. Ya se ve el carácter pragmático, utilitarista, individualista y temporal...". 
para la manifestación de nuestro ser espiritual hasta la conmoción, cuando se sale en procesión. Esto constituye no sólo la posibilidad de tener una experiencia religiosa, sino también desgraciadamente su puerta de salida inmediata, porque transforma al cristianismo en una religión anestésica, tranquilizante, compensatoria, pero sólo para un rato ${ }^{115}$. La dimensión comunitaria nos porta a un replegarse sobre el propio yo, a un sentirse bien (los demás no se identifican, no son un heteros, sino que existen en cuanto mi satisfacción, mientras sirven para conseguirla); el alza de los valores, de la ética como centro de lo religioso en este caso diluye la verdad de lo que se cree, no importa el fundamento, la experiencia del ser, sino el hacer, actuar, pero siempre que sea en compensación de mi estabilidad (salimos en procesión, vamos a la vigilia pascual, colaboramos "desinteresadamente", pero no aguantamos a nuestro padre, no trabajamos con la dignidad y competencia necesarias o explotamos a nuestros trabajadores...); el residuo cultural permite que tengamos un punto común de contacto, pero nos lleva a la pérdida de identidad con nuestra autenticidad, con los orígenes de una genuina tradición. Es un patrimonio histórico común que nos permite coincidir y compartir... procesión, andamos juntos a Santiago, nos conmovemos en los encuentros internacionales con el Papa... pero no compartimos la hondura de aquella experiencia originaria, sino que, estando juntos, nos contagiamos la muerte, porque todo es vacío interno. Y, por último sin redundar ya mucho más, la emotividad que nos exige la experiencia de la satisfacción en el aquí y el ahora. La intensidad emocional de estar en la plaza del Obradoiro después de la larga peregrinación, la conmiseración de un rostro anciano de nuestro Papa, el compungimiento del viernes santo... todo esto, siendo necesario para una experiencia religiosa, se convierte hoy día, en el obligado fin de la misma. La idéntica puerta de acceso a la religiosidad es aquélla que te coloca fuera, porque las diversas dimensiones se utilizan con códigos ajenos al cristianismo y lo han envejecido lentamente hasta el punto de contemplarlo dañado por un gran cáncer... vivimos en visos de muerte.

Este análisis de la primera parte ha pretendido mostrar cuál es el escenario religioso que se vive en España; tras ser conscientes de la irrupción del neopaganismo como respuesta a un mundo desencantado-nihilis-

115 Es interesante el texto de MARDOnEs, J.M., ¿Adónde va la religión?, 71-89, donde nos expone un rico análisis de lo sagrado común en el cristianismo y los nuevos cultos; a partir de él podemos tener una ligera idea de lo que compartimos con ellos en sentido positivo, pero también del problema que corremos si caemos en sus criterios, sobre todo en el gnóstico y el espiritualismo personal. 
ta y confiado en la técnica, he concluido también con el hecho de que el cristianismo, aparte de disminuir en cantidad, cae en calidad, es decir, no sólo decae en número, sino que vive en una especie de sincretismo que le aparta de su identidad y frescura original: la Revelación de Jesucristo.

\section{VOLVER A PARTIR DESDE JESUCRISTO: CRISTO COMO GOZNE PARA EL RETORNO DEL CRISTIANISMO}

\section{1. ¿POR QUÉ EL CRISTIANISMO NO FUNCIONA COMO SIS- TEMA RELIGIOSO DENTRO DE LA RECUPERACIÓN DEL MISTERIO?}

\section{A. 1 Diverso código de la ley del mercado}

Fundamentalmente lo que intento hacer en este primer apartado del segundo capítulo es hacer el paso del análisis de la religiosidad a la propuesta cristológica; exactamente, lo que pretendo, antes de ofrecer una posible respuesta es analizar por qué el cristianismo actual no es ya en sí tal propuesta válida. En otras palabras podría decir que si lo que nos muestra la religiosidad actual es que hay un fervor por lo religioso, ¿por qué el cristianismo no entra dentro de este marco como una alternativa más? ¿Por qué, en cambio, pierde vigor? ¿Por qué se debilita, es cuestionado, no es atractivo? Lo que en general diré en este apartado será que, porque ni ha valorado lo positivo del paganismo (que por otra parte siempre le ha pertenecido) ni vive su auténtica vocación; de hecho vive con códigos ajenos con un barniz externo diverso, como si mantuviera una fachada diversa a la religiosidad, pero con un mecanismo interno confuso y fosilizado.

\section{Una religión no creada por el hombre}

Lo que he denominado, según expresión de Sánchez Nogales, como efecto city religion es precisamente lo contrario a la Revelación concreta y personal de Jesucristo. Una galería de divinidades dentro de una confusión del misterio no puede ser una concepción más contraria al Dios de Jesús. Pero, como ya está sugerido, lo peor de esto es la consecuencia de este escaparate de religiosidad a medida; al final lo que queda es una religión construida por el hombre, un acceso completamente desde abajo, desde el hombre, pero que, en la mayoría de las ocasiones, se queda en la misma dimensión ${ }^{116}$.

116 Sobre el Dios personal y relacional $C f . L G 6,41,42$; $G S 12,13,14,21,19$, 45 ; $U R$ 2; $A G 2,10,12,15,40$. 
Una religiosidad que, como decía en el primer capítulo, tiene como fondo el calificativo de dionisiaca-prometeica, implica necesariamente dos cosas: el acceso al misterio desde el hombre; la proyección del hombre en el misterio. Por tanto, no sólo se deriva la consecuencia de la construcción de la divinidad desde el hombre, sino que además se configura a la propia medida; no es ya dios lo que encuentro, sino la proyección de mis necesidades. Lógicamente, una divinidad, como decía en la primera parte, tan "individual", no personal, tiene como ventaja el hecho de estar versus hominem, pero el riesgo es que hablamos de una construcción sin fundamento externo, sin que pueda interpelar verdaderamente a la persona.

$\mathrm{El}$ cristianismo, en cambio, tiene un principio interpelante constante: la Revelación en Jesús, que nos lleva siempre a un diálogo Dios-hombre ${ }^{117}$, para llevar a este a su promoción. El problema, ciertamente es que, teniendo este contraste-fundamento, sin embargo hemos dejado de lado el carácter personal del cristianismo ${ }^{118}$.

\section{Una religión para el hombre, pero desde Cristo}

Queda claro que el cristianismo no entra en la lógica del mercado entendido como un mecanismo que se configura según la demanda de las exigencias (más preciso, capricho) del hombre. Como acabo de mostrar estamos en un límite un tanto vago, porque a primera vista podría ser un enunciado adecuado y necesario para una religión, pero aquí matizaré mejor el contenido. El paganismo ha sido capaz de conectar con el hombre concreto y mostrarle un tipo de racionalidad diversa que ha ayudado y ayuda al hombre a ir adelante con el peso de la vida. El problema es que lo hace sin cuestionar el mundo, sin comprometerse con él. Las respuestas concretas para el hombre con un rostro definido no es que vengan de un más allá, sino que son auto proyección de la misma persona, de ahí que llamamos individualización más que personalización, porque en definitiva lo que uno se encuentra como divino es una especie de yo deificado que me justifica, no cuestiona y satisface.

El cristianismo por su parte, no ha estado a la altura de formular propuestas concretas, que aportaran al hombre una mayor plenitud o resolviera los problemas de la cotidianeidad ${ }^{119}$, arrastrando grandes respuestas

117 Cf. GS 19, "Fin dal suo nascere l'uomo é invitato al dialogo con Dio".

118 MARDONES, J.M., ¿Adónde, 212: “El reto consiste en crear sensación de hogar y de seguridad sin exigir a cambio más dependencia grupal o institucional de la necesaria. Ofrecer protección y un espacio de libertad al hombre de hoy será el gran reto de las comunidades religiosas que quieran ser verdaderamente humanas".

119 Ibid. 218: "Lo que sí sabemos es que sin el impulso ético solidario, sin la conciencia de nuestra co-dependencia y co-responsabilidad por el hecho de compartir una misma 
que, en definitiva estaban vacías de vida, de profundidad. No obstante esto, la ventaja es que en el centro de la Revelación, en Jesucristo, tenemos a uno que va contra la oferta y demanda. Justamente, la encarnación supone la máxima expresión de Dios de convertirse en don para el hombre, de entrar en diálogo con él, de ser en definitiva una respuesta de sentido para la persona. Pero siempre permanecerá Jesucristo como punto de referencia específico que cuestiona, que no se deja manipular, porque no está diseñado para cubrir unas exigencias, sino para ofrecer una plenitud de vida desde el don de sí mismo. La lógica del cristianismo no es la de comprar según conveniencia, sino la de vivir comprometido con el mundo en la dinámica del otro ${ }^{120}$.

\section{A. 2 Diverso código de la estabilidad}

\section{El cristianismo confortable}

Una vez más, es justo apreciar la dimensión humana que aporta la nueva religiosidad, pero, por otro lado, hemos visto que otro de los vicios a los que porta este tipo de "humanidad" es construir un rinconcito apacible donde se pueda vivir sin entrar en crisis. Lógicamente, como consecuencia de una religiosidad de mercado, tenemos que lo que se consume es lo que hace estar bien a uno. Como consecuencia de aquella estetización de la realidad, la persona busca vivir bien, justificando el sistema. La realidad, y la persona como individuo que pertenece a ella, no puede ser cuestionada porque el mecanismo del paganismo es justificar el propio status.

El cristianismo, desde luego, también ha caído en este juego. Las acciones de voluntariado que se realizan entre los más jóvenes, las limosnas de los más mayores, las oraciones porque este mundo se convierta son

\footnotetext{
historia, no hay posibilidad de plantear verdaderas soluciones". METZ, J. B., Sulla teologia del mondo, 53: "La fede è piuttosto fede storica, fondata su un evento storico, unico, irripetibile: sul sì e sullo amen definitivo di Dio all'uomo nel suo Figlio Gesù Cristo. Sempre e necesariamente la fede cristiana, se non vuole essere dimentica della sua propria essenza, ha a che fare con la storia; nella storia, infatti, avviene l'apertura alla trascendenza che sana e che salva. Sempre e necessariamente la fede cristiana, quindi, ha a che fare con il singolo momento storico, attraverso il quale soltanto essa penetra nel grande contesto dell'unica esistenza storica. Rimanere fedeli in ogni situazione storica presente a una origine storica, significa però dare a questa origine, el presente un futuro e cioè: comprendere il presente come speranza".

${ }^{120}$ Latourelle, R., L'uomo e i suoi problemi, 7: “...Cristo e solo Cristo dà un senso non soltanto alla condizione umana presa nel suo insieme, spiegando all'uomo la sua vocazione di figlio chiamato per grazia alla vita e gloria di Dio, ma anche ai problemi concreti e particolari di questa condizione".
} 
signos, entre otros tantos, que hacen de compensación para la persona. No se vive una vez más desde el don de sí, sino que se actúa, creyendo ayudar para la transformación de este mundo, pero es tan sólo una acción para no cuestionar la realidad ni mi vida. No se pone en cuestión lo que está detrás, sino que se ponen parches.

A primera vista surgen dos problemas: generalmente este tipo de acciones son tan fugaces como la duración de un estado pasajero personal. Uno se compromete con el voluntariado, porque, en el fondo lo necesita, pero no hay una opción fundamental de fondo, que le dé solidez y continuidad, por lo que, cuando desaparece la situación ocasional por la que se hace, se deja tal compromiso, porque no hay fundamento. El segundo problema que surge es, en definitiva se vive una ética egocéntrica, cuyas acciones están dirigidas al mantenimiento del individuo en una situación estable ${ }^{121}$.

\section{Lo estable en la triple cara del egocentrismo, despersonalización y pri- vatización}

Por concretar diversos matices de este confort religioso que vivimos, he querido mencionar en este sub-apartado tres realidades que tienen que ver entre sí. Apenas he afirmado que el cristiano, junto con el religioso pagano, vive inmerso en una ética egocéntrica, porque se vive en el primado de las acciones sobre el del fundamento, buscando, en definitiva la autosatisfacción. Creo que es una consecuencia de la pérdida del valor de la religión del Dios personal de la Revelación; en este sentido entiendo despersonalización del cristianismo, tal y como se vive en la lógica neopagana. Es cierto que supone una aportación positiva a la persona, pero falta todo un proceso de personalización, de elaboración propia, de asunción vital. Sin embargo, actualmente lo religioso se vive desde la extrañeidad, desde la separación, desde la absoluta trascendencia ${ }^{122}$.

121 El mejor ejemplo que puedo traer a colación es mi propia experiencia con el trabajo pastoral con los jóvenes. El último caso, entre tantos, aconteció la semana pasada con un grupo de adolescentes de 15 años en la Parroquia de Santa Prisca, Roma, los cuales, entre otras cosas, hacen con cierta periodicidad una cena con un grupo de pobres. Ante la pregunta sobre si tenían como base de tal acción a Cristo o sobre si harían tal compromiso en otra parte dependiente de una institución civil, la respuesta fue, negativa la primera y afirmativa la segunda, ya que "Io importante es hacer algo bueno, gracias a mí y por mí" (sería la traducción literal de una de las respuestas de los chavales).

122 La recuperación de la dimensión personal debe tender a una integración justa de las dimensiones de la persona y no a una fragmentación o tendenciosidad sobre una de ellas; URREA VIERA, JUAN CARLOS, "New âge". Visión histórico-doctrinal y principales desafios, Santafé de Bogotá 1998, 52: "El desafío será que la antropología continúe destacando 
Como fruto también de esta extrema individualización, como proceso contrario a la personalización, se da la privatización de la experiencia religiosa. Individualización, porque, al final, a ese misterio común podemos llegar todos por nuestra condición hermenéutica, pero haciendo el recorrido solos. La falta de una comunicación personal desde el misterio hasta el hombre, hace de tal misterio una realidad así manipulable, cuanto interpretable, si todos podemos decir de todo respecto al religioso, debemos por fuerza admitir que cada experiencia debe ser aislada, porque privaría mi capacidad de interpretar. La única forma de vivir esta religiosidad es a través de este "respeto" hermenéutico, que me limita poner en cuestión el acceso del otro.

$\mathrm{Y}$, precisamente por esa individualidad interpretativa, la religión se privatiza, pierde la dimensión comunitaria, el contacto con los demás. Ese mayor respeto por los demás, lo que provoca al final es la absoluta ausencia respecto del otro; en definitiva, una religión que se vive desde la esfera de lo privado, sin un fundamento y vuelta sobre sí mismo no puede ser sino estable, confortable, sin fuerza interpelante ${ }^{123}$.

\section{La exigencia del profetismo}

Como alternativa el cristianismo debe recuperar su esencia proféti$\mathrm{ca}^{124}$, su centralidad de la denuncia. Nuestra religión ha olvidado por completo que no puede vivir si no es desde el mecanismo de la relacionalidad, desde la "otredad" (alteridad), porque un Dios que se ha volcado en el hombre, haciéndonos a su imagen, implica que no podemos vivir si no es desde el diálogo, la relación, la comunidad: el amor ${ }^{125}$.

do en todo momento la dignidad del ser humano, uniendo lo racional, lo emocional, lo social, lo moral, lo ecológico y lo místico".

123 SÁNCHEZ NogALES, J.L., La nostalgia, 60: "La oferta específica de la religiosidad alternativa para el sector afectado de angustia psíquica y espiritual es la de seguridad, según he indicado ya, sin descartar las otras dimensiones enumeradas. Seguridad frente al desconcierto reinante, como medio de contrarrestar la angustia y el miedo a la muerte individual y colectiva".

124 MARdones, J.M., Postmodernidad, 130: "Funcionarán, de hecho, como legitimantes indirectos de un reordenamiento del sistema de valores para superar la disjunción entre los sistemas económico y político con el cultural: una tarea que convierte a la religión en una tecnología terapéutico-social. Los grupos que vivan el cristianismo como experiencia, poniendo el énfasis en lo emocional y lo subjetivo, funcionarán como rincones particulares, oasis privados, que se mantendrán mientras aseguren a los individuos el bienestar comunitario o el desarrollo personal que se pretende".

125 Cf. Gn 1, 27; "La Sagrada Escritura enseña que el hombre ha sido creado a imagen de Dios, capaz de conocer y amar a su Creador... Pero Dios no creó al hombre solo: en efecto, desde el principio los creó hombre y mujer. Esta asociación constituye la primera 
Por otra parte, al hablar de una religión personal, entendemos que la centralidad de la misma está en la relación en reciprocidad con Dios y con los hombres; nuestro objeto no es una teoría, sino una persona y por ello el proceso religioso lleva a una asunción, configuración personalizada. Lo público y lo personal, así como el antropocentrismo son las alternativas al anterior sub-apartado.

Haber olvidado nuestra esencia propiamente judeo-cristiana ha hecho evaporar todos estos matices del centro de nuestra fe en Dios: el amor. Y este amor no es un sentimentalismo afectivo, sino la lógica de quien vive desde y para el otro, porque el centro del sistema es el don de sí, el vaciamiento existencial o kénosis. Por tanto, una religión de la lógica del amor que pone al hombre en el centro, a la comunidad-sociedad, sólo puede ser profética, porque en el momento en que la humanidad está sofocada ante nuestros ojos sólo puede quedar la denuncia como respuesta, denuncia encarnada en acciones concretas desde la oblación, el regalo de la propia existencia ${ }^{126}$.

\section{A. 3 El cristianismo se apaga porque vive desde estos códigos ajenos a su esencia}

Mayor desarrollo del componente helenístico-pagano del cristianismo127

Finalmente, recogemos la idea general presentada al inicio de este apartado, para reafirmar que el problema como telón de fondo es que el cristianismo funciona más con mecanismos, recursos, lógicas ajenas a él. De hecho, después de 2000 años de vivencia e interpretación del evento Jesucristo, creo que hay una descompensación exagerada del desarrollo helenístico-pagano, respecto al judeo-cristiano, lo cual, necesariamente

forma de comunión entre personas. Pues el hombre es, por su íntima naturaleza, un ser social y no puede vivir ni desplegar sus cualidades sin relacionarse con lós demás", GS 12, cf. Ibid. 24.

126 La recuperación de la centralidad del Dios bíblico sobre el amor ha llegado en nuestros tiempos precisamente a través de un filósofo judío, que, fiel a nuestro común origen, desarrolla la centralidad de la relación y el amor. Puede consultarse para intuir su pensamiento concentrado su obra más conocida: BubER, M., Yo y tú, Nueva visión 1994.

127 En general lo que plantearé en este apartado y lo que queda de la tesis es que falta toda la perspectiva judeocristiana de la secularización. Metz, Bonhoeffer, Gogarten, Schillebeeckx, Duquoc son claros ejemplos de esta necesaria recuperación de una teología esencialmente secular, porque Jesús fue quien la portó en su manera de entender el mundo; los diversos matices sobre la política, liberación, estética... son todo consecuencias de la secularización que porta la visión judeocristiana de la Revelación. Asimismo, aunque de manera más radical, Hans Küng expone esta tesis de la hiperhelenización del cristianismo propiamente desde el inicio; Cf. KüNG, H., El cristianismo. Esencia e historia, Madrid 1997, 126-295. 
implica una pérdida importante de la interpretación de la Revelación, por no decir su desarrollo principal, angular ${ }^{128}$.

Ciertamente es que los Padres así como el desarrollo de la teología posterior hasta nuestros días fueron fieles a una consecuencia del principio de la Encarnación: reinterpretar el evento para una situación concreta, es decir, revitalizar la kénosis, ser fieles a su esencia, pero, por otro lado, a lo largo de la historia, al querer ofrecer una concepción tan definitiva y racional, la frescura del Evangelio se ha evaporado.

La conceptualización de Jesús en el Logos, la soteriología hermética segura de sí misma, la fosilización sacramentaria de la vida litúrgica, me atrevería a decir al estilo pagano (desde la misma consagración hasta la oración de los fieles, según mi parecer transparentan un núcleo ritual mágico-pagano, donde se espera que el mago-gurú... intervenga, sin que aquello tenga ninguna conexión con la vida) son síntomas de un desarrollo desproporcionado de ese sentido helenista-pagano ${ }^{129}$.

La ética, la liturgia, la misma, y sobre todo, la teología han encerrado el mensaje de las parábolas en fórmulas casi definitivas y, por lo tanto, muertas. El lenguaje parabólico, para nosotros nos tiene que llevar a una concepción metafórica, hermenéutica, un lenguaje de apertura, de sugerencia, completamente diverso al reduccionismo helenista, por no hablar de degeneraciones mayores como el pensamiento científico ${ }^{130}$. Ya los $\mathrm{Pa}$ dres intuyeron el quid, versando sus interpretaciones en alegorías ${ }^{131}$, pero

128 Cf. GonzÁlez FAUS, J.I., Calidad cristiana..., 185-187. El problema, como plantea al autor, no es la "necesaria" helenización del cristianismo en un primer momento para demostrar su capacidad siempre posible de inculturación o "re-encarnación", sino de "imponer al Asia o África dictaduras culturales bajo la apariencia de exigencias de la fe" ( $p$ 185). La cuestión se sitúa, emtre otros puntos de reflexión en que la teología "occidental haya podido hablar tanto de Dios sin recurrir demasiado a Jesús. Éste aparecía más como Fundador que como Contenido del cristianismo" (p 186).

129 Cf. Ibid. 188-194. El término Logos, inculturación-traducción del hebreo Dabar, supuso más que una mera actualización del lenguaje bíblico. El Logos helenista nos encauza a una Verdad-Palabra Absoluta, un conjunto de verdades seguras de sí mismas que se configuran-concretan en un corpus de doctrinas que salvan, "comunicación de vedades" ( $p$ 189) y no tanto a la Palabra que se encarna, se hace compromiso y acción liberadora. La Dabar no es la palabra para ser conocida, aprendida y confesada, sino la acción comprometida liberadora que nos llama a ser respondida, in-corporada, re-encarnada y testimoniada. Ante una religión de la confesión de fe, el cristianismo es una fe del testimonio en el amor o la fe que confiesa la Verdad absoluta como testimonio personal del Amor absoluto.

130 ORTEGA Y GASSET, J., Obras completas III, Madrid 1964-83, 372: "La metáfora es probablemente la potencia más fértil que el hombre posee... parece un trabajo de creación que Dios se dejó olvidado dentro de una de sus criaturas al tiempo de formarla".

131 Especialmente la conocida escuela alejandrina (Cirilo de Alejandría, Dídimo el Ciego) siguió más esta corriente interpretativa, encontrando en Orígenes su máximo exponente. 
sin embargo, desde mi punto de vista con otra perspectiva: no tanto con la intención de sugerir, como de identificar ${ }^{132}$. La pérdida de esta dimensión simbólica, de narrar la vida o de revitalizar la narración va contra lo esencial del cristianismo y otro síntoma más de esa tendencia helenista-pagana, que trata más de conceptualizar y de confundir y distinguir lo divino con lo mundano ${ }^{133}$.

Como consecuencia, hoy día nos hallamos ante un cristianismo que ha absorbido más la lógica de este neopaganismo en nuestros días ${ }^{134}$. Tanto los mayores como los jóvenes españoles (aunque éstos lo vean con otra mentalidad más escéptica) viven un cristianismo excesivamente trascendente, una religión apartada de la vida, mágica. Hechos tan fundamentales, como decía antes, de nuestra religión: la consagración, la oración de los fieles, la providencia (incluso "exconjurando" tormentas para que cayeran en el pueblo de al lado), la salvación externa a la vida, las penitencias tarifadas, pero tranquilizantes y despersonalizadoras han provocado una deshumanización del cristianismo, una "des-encarnación" de la centralidad de la Revelación, un infantilismo-heterónomo moral. En definitiva, nos queda la magia de una sacramentalidad ligada a su celebración social y una ética aceptable de alguien que vivió hace 2000 años. Por otra parte, como intentaré proponer al final de mi reflexión, este mismo hecho quiere decir que nos queda todo, es decir, nos encontramos ante un cristianismo debilitado y contaminado, pero con toda su originalidad judeocristiana por estrenar: todavía tenemos que mirar a Jesús con ojos nuevos.

132 Efectivamente, según la definición que recojo del $D R A E$, la alegoría, como metáfora continuada, aun teniendo un sentido recto y otro figurado, creo que viene usada, para identificar, para cerrar el discurso; es decir, lo que externamente te lleva a un sentido figurado, en definitiva viene interpretado en otro nivel, dejándolo encasillado. Lo que yo planteo es que las parábolas no tienden a identificar, sino a sugerir otra realidad, no a cerrar un discurso, sino a abrirlo, no a extraer el significado escondido de la realidad, sino a ponerte delante de la realidad como misteriosa. "Alegoría"(cuarta acepción) en $D R A E$, Espasa Calpe, Madrid 200122, 67: "Figura que consiste en hacer patentes en el discurso, por medio de varias metáforas consecutivas, un sentido recto y otro figurado, ambos completos, a fin de dar a entender una cosa expresando otra diferente".

133 MARDones, J.M., La vida del símbolo, Santander 2003, 258: "Sospechamos que el antídoto camina de la mano de una vida alternativa donde el símbolo se haga parábola de vida, sugerencia de otra cosa, compasión efectiva, recuerdo peligroso, apertura a lo otro y diferente, diálogo con el Tú misterioso y cercano. El símbolo es el arma de la evocación de lo distinto, presentiza lo ausente, dispara la imaginación hacia lo que todavía no existe pero puede ser. Sin símbolo quedamos presos de lo que hay...".

134 Con lo expuesto hasta el momento, se entiende que el prefijo neo- se refiere más a la novedad formal, externa de su manifestación, que en cuanto a su contenido, ya que, de alguna forma ha preexistido, subsistido y resurgido en el cristianismo. 
Esta contaminación ahoga el profetismo y pone en contradicción al cristianismo

Es lógico que si se han desarrollado unas orientaciones se hayan dejado de lado otras. Como subrayaba en el subapartado anterior, la exigencia de denuncia de una fe $\mathrm{e}^{135}$ basada en la manifestación de un Dios trinitario, de un Dios que es misterio de comunión, ha decaído en función de esta religiosidad a-personal136. No es posible vivir según la oferta y la estabilidad, siendo al mismo tiempo profeta, en primer lugar, porque la vida no es estable, sino conflicto. Un Dios que se comunica bajo la lógica del amor, exige una corresponsabilidad hacia el mundo, hacia sí mismo, pero jamás el amor y el confort pueden andar de acuerdo, porque el verdadero amor crítica toda pretensión de anular la identidad de cualquier hombre: todo atentado contra la autonomía comunicativa del hombre exige la denuncia desde el amor ${ }^{137}$.

Pero no sólo se constata esta confusión, esta contaminación de códigos, sino que creo que además puede resultar un virus interno para el cristianismo. Creo que he intentado mostrar una postura neutral de cara a la aportación que esta atmósfera pagano-nihilista puede hacer al cristianismo, pero el discurso es diverso, cuando un sistema adquiere notas, rasgos de otros sin ser consciente y perdiendo la propia identidad. He aquí el peor problema, ya que en España se vive estirando viejos esquemas que no dan ya respuestas a nadie, pero con estos mecanismos en su interior y además

135 Sin querer caer en generalizaciones peligrosas y lejanas de la verdad, sí querría acentuar que la distinción entre fe, que personaliza y humaniza, y religión, que encuadra y niega la creatividad, está precisamente cuando la religión se juega en la autorreferencialidad, en la city religión, en el confort.

${ }^{136} \operatorname{Cf} E f 1,3-5 ; \operatorname{Rm} 8,29 ; \operatorname{Rm} 8,15-17 ; E f 4,7$. La idea que se presenta es la de que la conformación trinitaria de la persona por la asimilación filial no puede pararse en una abstracción, sino que nos lleva a la lógica de la comunión entre los hombres, tomando en serio la responsabilidad histórica sobre el mundo. AMATo, A., Gesù il Signore. Saggio di cristologia, Bologna 1999, 619: "L'incorporazione a Cristo pone il fedele in relazione intima con le persone trinitarie e, allo stesso tempo, stabilisce un nuovo rapporto con gli uomini [...] Uniti a Cristo i battezzati non costituiscono un coacervo informe di chiuse esistenze individuali, ma un organismo vivo e pieno di correlazioni. Ogni fedele non solo ha un suo intrinseco riferimento a Cristo, capo del corpo mistico, ma anche una sua originale funzione e interrelazione con le altre membra".

137 MARdones, J.M., Postmodernidad, 129-130: "Peligroso, sin embargo... sobre todo, una religiosidad cristiana tan centrada en lo espiritual que desconozca que para el cristianismo la salvación se realiza en la realidad mundana de la historia, y no exclusivamente en la conciencia o el sentimiento de los creyentes. Pero se tiene una mala comprensión de la fe cristiana cuando, so pena de dedicarse a actividades específicamente religiosas, el creyente (o la comunidad) se sitúa fuera del acontecer y batallar mundanos". 
sin saber cuál es su verdadera identidad (tal vez, porque cualquier creyente de a pie, nunca la ha sabido) ${ }^{138}$.

Pero aún más, si consideramos que inconscientemente existe una reacción diversa delante al cristianismo o a la lógica del mito. Delante a una tragedia, una de las catástrofes que suceden en la vida, el sistema religioso del hombre salta, reacciona para dar una respuesta; según el mito, hemos dicho que, ante el devastador último tsunami, (o por no ir más lejos las múltiples, tanto tranquilizadoras cuanto inútiles, oraciones por las vocaciones) los mecanismos se activarán para reajustar mi/el sistema sin cuestionarlo (voluntariado, ofertas, acciones humanitarias...), de tal modo que yo quede confortablemente satisfecho; podemos decir que el cristianismo, no sólo ante las grandes tragedias, sino en su cotidianeidad ofrece las mismas respuestas (aparte de todo lo anterior, podemos adjuntar alguna oración o vigilia), pero el problema es que ante las resistencias de la vida, al mito no se le pide explicaciones, porque no entra en sus reglas, en su lógica y, por eso, tanto si su aplicación reajusta o no, es eficaz o falla no se le piden responsabilidades, porque no le compete. Sin embargo, y he aquí el colofón de esta decadencia del cristianismo, nuestra religión, actuando con los mismos mecanismos, al final de todo el proceso nos pone delante a Dios que, precisamente, nos ha dejado en este mundo, ante un Dios responsable-irresponsable de la creación.

138 Torres QueIruga, A., Fin del, 204-205: “Un primer intento fue el deísmo: Dios como el gran relojero o el genial arquitecto que, in illo tempore, creó el mundo como una máquina perfecta que ahora marcha por sí misma, mientras él permanece allá en el cielo sin ningún tipo de presencia activa. Una mentalidad que no deja de habitar aún ciertos estratos de la conciencia colectiva, pero que de ningún modo podía satisfacer a la conciencia religiosa de un dios vivo y operante (ése fue el verdadero sentido de la protesta de Pascal contra el Dios de los filósofos). Sin embargo la insatisfacción no llevó con toda consecuencia a una transformación radical. Ha habido cambio, pero se ha quedado a mitad de camino, originando lo que en alguna ocasión he llamado deísmo intervencionista: Dios en el cielo, atento al mundo, pero más bien pasivo y actuando sólo con intervenciones puntuales, de carácter más o menos milagroso, de ordinario movido, o bien por las peticiones y los sacrificios de sus fieles, o bien por la recomendación de los santos e intercesores. Un tipo de piedad enormemente extendido, puesto que empapa gran parte de las devociones y de la misma liturgia, y que incluso contamina profundamente la teología. [...] Pero, si esto resulta inviable, tampoco aparece una salida fácil que eluda el dilema de obligar a la teología a escoger entre el dios pasivo o el dios intervencionista de la piedad tradicional". 
2. EL DIOS DE JESUCRISTO, CONTRARIO AL SACRO ANÓNIMO

\section{B.1 Cristo, hombre que interpreta a Dios y la religión en diverso modo}

Jesús rompe la interpretación de Dios y la religión a través de la secularización

Comienzo aquí no todavía la parte de propuesta en sí, pero sí el fundamento de la diferencia, la ruptura que Jesucristo opone a la religión pagana, para darnos cuenta de dónde debemos repartir, para fundamentar una nueva orientación. La primera cuestión que surge es que Jesús se opone bruscamente a la concepción greco-helenista de la existencia. En otras palabras, podría decir que rompe con la interpretación de la religiosidad de su época, de la separación del sacro y el profano, de la cosmovisión clásica, porque, precisamente interpreta la existencia de otra manera. A lo largo de los evangelios, podemos leer cómo Jesús mismo interpreta su vida desde abajo y es a partir de las situaciones, signos concretos de su experiencia cotidiana desde donde interpreta la nueva existencia, la nueva forma de relacionarse del hombre con Dios, del hombre con los hombres, del hombre con el mundo139.

La secularización introducida por Jesús implica una historización de la experiencia concreta de la existencia, exigida por el corazón de nuestra Revelación. La historización de la existencia implica poner en práctica el ejercicio de libertad, la posibilidad de decidir, elegir, hacer proyecto, el imprevisto. Dios se hace historia, entra en la historia para hacernos cocreadores $^{140}$ a través del ejercicio de nuestra libertad; libertad y fe que están en continuo desarrollo y tensión porque están expuestas a un futuro, Dios. Por tanto, la libertad como núcleo de la existencia exige una responsabilidad ante Dios y al hombre-mundo141.

139 SCHILlEBEECKX, E., Gesù, la storia di un vivente, Brescia 1976, 26: "l'uomo Gesù, nel senso umano della parola: una persona umana, è per me punto di partenza di tutta la riflessione, mi sembra una verità lapalissiana che non ha bisogno di essere provata".

140 Gn 1, 28; Sal 8, 6-9

$141 \mathrm{Al}$ distinguir en el primer capítulo secularización de secularismo, no sólo pretendía exponer el lado negativo de éste, sino sugerir también la interpelación que provoca al cristianismo que no entiende su esencia secularizada; efectivamente un cristianismo que no entiende como secular, es decir, como responsable del mundo se transforma en la proclamación de la negación de la presencia de Dios en la historia, la falta de credibilidad. Ésta es la afirmación que debemos agradecer al nihilismo, porque nos ha ayudado a reflexionar 
El error metafísico tradicional, y del que todavía se respira en la mayor parte de la atmósfera cristiana, es haber dualizado el divino y el profano, el haber distinguido su relación. No es que no tengamos necesidad de la metafísica, porque somos seres metafísicos, pero el problema es haber adquirido y proyectado en la teología y experiencia cristianas unas categorías metafísicas que van contra la Revelación: el cristianismo no puede ni utilizar, y todavía menos dividir, las categorías sacro-profano, porque su esencia es la historia ${ }^{142}$.

Por tanto, Jesús modifica la lectura del mundo y de la salvación, porque ya no acontece como algo sopra-esencial, sino en la historia misma; mete la salvación en el desarrollo de la historia y la llama a un proceso interpretativo dentro de unas coordenadas existenciales y personales. Esta óptica neotestamentaria provoca una perspectiva diversa, porque el centro de la Revelación existencial-personalista nos abre el camino de la libertad, basada en la cofiliación en Jesucristo, que, a su vez, nos remanda a la corresponsabilidad ${ }^{143}$. Efectivamente ser hijo implica una semejanza con el Padre, pero también, y muy importante, una diferencia que produce una identidad. Ser hijo implica actuar la propia identidad configurada desde la libertad y corresponsabilidad y siempre en el desarrollo de la historia ${ }^{144}$. Por fuerza, nuestra identidad debe configurarse en la historia, nuestra vocación debe hallar su plenitud en la

sobre dónde está nuestra identidad-credibilidad: la historia ha mostrado un Dios apático, indiferente, ajeno al mundo.

142 Efectivamente negar la condición metafísica de la persona sería absurda, ya que, como queda demostrado, el hombre se trasciende, busca responder preguntas que están más allá de lo que aparece, de la física, precisamente, porque en él surgen tales preguntas como inherentes; de ahí su esencia metafísica. Alfaro, J., De la cuestión, 27: "el hombre no podrá plantearse la cuestión de Dios sino porque la lleva impresa en las estructuras que condicionan la existencia humana y sus experiencias fundamentales; la cuestión de Dios (si la hay) tendrá que pertenecer a la precomprensión vivencial que el hombre tiene de sí mismo".

143 PANIKKar, R., La pienezza dell'uomo. Una cristofania, Milano 2003³, 133: "In definitiva, la nostra filiazione è reale. San Paolo ricorre alla metafora del corpo di cui Gesù Cristo è il capo e noi le membra - ma tutti partecipiamo della stessa vita. Questo è precisamente il mistero di Gesù Cristo: pienamente umano e pienamente divino senza confusio ne, ma anche senza dicotomia... Siamo ancora pellegrini, ma sentiamo anche noi che siamo uno con il Padre. Sta scritto che ci è stato dato lo Spirito $(\operatorname{Rm} 8,9)$ che ci fa conoscere che dimoriamo nel Figlio (Jn 14, 23; 1 Jn 3, 24)".

144 Esta perspectiva de la recuperación de la importancia de la historicidad nace del que se puede llamar el padre de la teología de la secularización, Gogarten, quien apuesta por la absoluta vivencia cristiana en la historicidad personal; GogARTEN, F, Demitizzazione e chie$s a$, Brescia 1981, 55: "Qui si tratta di decidersi per il pensiero storico o per quello metafisico. Una volta che si è incominciato con il pensiero storico -e abbiamo visto che e per quale ragione la teologia non può più fare altrimenti-, allora si debe pensare in modo storico anche la realtà con cui ha a che fare la fede e nei riguardi della quale essa ha veramente qualche cosa 
única dimensión posible que es la histórica y no esperar que caiga como un bloque del cielo, porque no hay realidades separadas; para el cristiano la propia identidad se encuentra en el mundo y en la relación, por lo que la autonomía no está reñida con la heteronomía, sea de los otros o de Dios, porque viene integradas. Una persona no puede llegar a su máxima plenitud si no es en la relación, por eso negar una "dependencia" de Dios es negarse a sí mismo, porque nuestro ser históricos exige por fuerza la relación ${ }^{145}$.

Todavía podemos decir que Jesús, como intérprete secularizante del mundo y de Dios, niega la condición divina del mundo, porque es criatura, es otra cosa que el panteísmo inaprensible o el mundo abandonado por Dios. Tanto una opción como la otra hacen de la libertad un juego, porque al final, el desarrollo de la identidad, el ejercicio de la responsabilidad queda limitado a las fuerzas o caprichos divinos. Jesús nos dice que no hay religiosidad cósmica, que las divinidades no se pasean entre los hombres, en definitiva, desacraliza el mundo. Pero, por otra parte abre la intuición de la santidad, por la que se separa ética y antropológicamente del paganismo; la religiosidad ritual bloquea la creatividad, la responsabilidad, la libertad, la identidad de la persona.

La fe no es hacia una cosa separada del mundo o sobre algo que nos rodea del día a la noche, sino algo que nos pone ante nuestras preguntas constitutivas, que se aleja de responder a nuestras necesidades. La fe nos hace asumir nuestro ser personas en el mundo y entender de diverso modo la relación con el mundo y Dios en la historia. A este punto, la persona está entre Dios y el mundo, desarrollando su libertad-identidad, siendo consciente de que Dios es Dios y el mundo es el mundo, pero no separándolos, sino relacionándolos. La diferencia hace la relación, la comunión; si dijéramos que Dios es el mundo, entonces habría una identidad y si los separásemos, caeríamos en una trascendentalismo divino, por el que el hombre estaría perdido desde su nacimiento ${ }^{146}$. Jesús, sin embargo, ha insertado el sen-

come un sensorio e un criterio di realtà. Per fare ciò non basta però neppure lontanamente definire tale realtà come realtà sovrastorica. In questo modo, fin troppo comodo, si può al massimo definire il problema di cui qui si tratta, ma non si può risolverlo".

145 De hecho el planteamiento de Juan Alfaro en su libro De la cuestión es que el hombre a partir de las relaciones con el mundo y la alteridad, por su propia naturaleza, puede llegar al conocimiento de Dios, que, en otras palabras, valdría decir llegar a la plenitud del propio proyecto de vida.

146 El planteamiento que expongo sobre la teoría de la secularización a partir de las categorías de filiación, libertad, corresponsabilidad, historicidad personal parten de la obra de Gogarten, F., Destino e speranza dell'epoca moderna. La secoralizzazione come problema teologico, Brescia 1972 (original en alemán de 1953). 
tido de la Salvación dentro de una relación con la vida, conservando la diferencia, para vivir la relación entre Dios y el mundo. Por eso no hay tiempo indicado para rezar, ofrecer sacrificios, cumplir la voluntad de Dios, porque no hay separación, sino continua relación. La madurez-identidad de la persona se encuentra en vivir esta doble relación Dios-mundo, que Jesús expresa en su máximo grado; somos criaturas, pero a la vez cocreadores nos recuerda ya el Génesis, pero Jesús encarna esta intuición veterotestamentaria, donde Dios y el mundo son diversos, pero en continua relación. La categoría de hijo es lo que nos hace entender la esencia del cristianismo, porque en el ejercicio de su libertad creativa y responsable se reconoce como diverso (criatura), pero en relación constante (cocreador) y no puede haber separación, sin caer en la fragmentación de la persona. Si separamos el sacro del profano o negamos la existencia de uno de ellos, ponemos una quiebra insuperable de la persona. He aquí la gran ruptura y novedad de Jesucristo, que de alguna forma se expresa en la ya citada Gaudium et spes 22: toda reflexión sobre la persona lleva al desarrollo del descubrimiento de Cristo y toda cristología debe venir para un mejor desarrollo antropológico. Jesús ofrece otro modo de relación persona, mundo, Dios integrándolos, pero no ofreciendo una propuesta extrínseca (la exageración de su divinidad nos llevaría al final a un trascendentalismo, que en definitiva, negaría su humanidad), sino histórica, e históricamente interpretad $a^{147}$.

\section{Entonces, ¿qué Dios conocemos en Jesucristo?148}

Propiamente a esta pregunta se responderá en los dos últimos apartados, pero parece oportuno ir concretando paso a paso la reflexión. Hemos visto los fenómenos del neopaganismo y del nihilismo como el escenario actual que configura la experiencia religiosa en nuestros días en

147 Cf. Lc 15,11-32. Aparte de los textos ya mencionados y más típicos, este pasaje del hijo pródigo, nos hace reflexionar sobre la corresponsabilidad nacida del concepto de la filiación. Ni el hijo pródigo ni el que permanece en casa entienden el sentido de la diferenciación, pero relación con el padre. El ser hijo implica tanto la corresponsabilidad en la obra del padre como del disfrute de todo lo suyo.

148 En otro trabajo que me ocupa, desarrollo a través de 3 textos evangélicos (Buen samaritano, el Padre y los dos Hijos, y Emaús) el Dios, persona, historia que revela Jesús; asimismo, me parece que estos relatos parabólicos, lejos de ideologizar el Reino, están además en consonancia con propuestas actuales que desvelan la plenitud de la naturaleza humana: una antropología relacional, una psicología post-analítica (Lacan) que recuerda que el estadio del espejo (reconocerse reconocido y comprenderse comprendido) es ni más ni menos que el retrato del abrazo del hijo pródigo y vestigio histórico siempre constante del símbolo protológico del nacimiento y metáfora escatológica siempre anticipadora y recreativa de la comunión total final. 
España; también he querido mostrar cómo el cristianismo de hoy, constreñido a interpretar en el mismo escenario, debe responder al mismo guión, perdiendo su identidad, porque es como meter en una comedia la estructura y contenido de una tragedia; finalmente, hemos llegado a la parte de la propuesta, después de haber hecho un análisis de la situación religiosa en España, para cuestionar y rehacer tal situación. Como primer punto, aunque parezca obvio, lo que he subrayado desde el título es la necesidad de repartir de Jesucristo, para reconstruir nuestra identidad, para ser conscientes que, rodeados de un nihilismo-pagano y contaminado por ello, debemos reelaborar la experiencia y la reflexión cristianas.

Precisamente mi intención, llegados a este momento, es que el re-partir de Jesucristo no quiere decir, volver a un punto de restauración, para volver a él, cuando las cosas eran de otra manera, como si las cosas no hubieran ocurrido (muchos de nuestros grupos lo pretenden así, negando precisamente la esencia histórico-hermenéutica del cristianismo), porque supondría aferrarse a una concepción de la Revelación que, como máximo sería adecuada para su tiempo, pero ilegítima y estrecha para nosotros (basta mirar alrededor, para ver la distancia entre la humanidad y el desafío antropológico apenas sugerido). Efectivamente, repartir de Jesucristo no significa que nos hayamos olvidado de que Cristo es el centro de nuestra fe, sino, desde mi punto vista, es intentar responder a estas tres preguntas: ¿Se puede conocer a Dios en Jesucristo? ¿Qué tipo de Dios se puede conocer en Jesucristo? ¿Qué implicaciones tiene esa específica Reve-lación de ese Dios concreto de Jesucristo hoy? Lógicamente debo partir de la primera afirmativa, para presentar la especificidad de Jesucristo. Lo que no se puede hacer es seguir transmitiendo bloques teológicos de generación en generación, dando presupuestos que no se corresponden con la realidad 149 .

El primer paso es partir de una cristología antropológica desde abajo (ascendente) ${ }^{150}$, de la verdadera humanidad de Jesús, sin arrojar pensamientos o concepciones divinísticas que hacen mayor gala al paganismo. Jesús nos ha mostrado que la historia, comenzando por la suya, es la vía de acceso a la plenitud de la persona y a la comunión con Dios, pero con

149 Cf. PIÉ-NinOt, S., La teología fundamental, 119-160, donde expone los diversos puntos de vista de algunos filósofo-teólogos que vinculan de distinta manera la exigida relación entre Revelación y persona, entre el acontecimiento Cristo y la situación concreta personal: Pascal, Blondel, Rahner, Balthasar, Tillich, Zubiri, Alfaro, Metz, Verweyen.

150 DuQuoc, C., Cristologia, Brescia 1972, 663: "È necessario avere i piedi solidamente piantati in terra per osservare il volo nell'aria"; "Il fatto che Gesù sia autenticamente umano e che, proprio per questa autenticità sia il Rivelatore, struttura tutta la teologia a titolo di principio; deve essere preso sul serio" (342)". 
las claves ya mencionadas. No es que Dios vendrá a la historia para dejar caer la Salvación como una losa, ni es que esté interviniendo mágicamente a cada momento, repartiendo gracias y males, sino que en el desarrollo de la filiación en el mundo, hallamos nuestra plenitud y nuestra relación con Dios: sólo, pues, partiendo de Jesús como verdadero hombre, podemos descubrir su propuesta divino-existencial, pero no, porque debamos olvidar su divinidad, porque como ya queda dicho, su interpretación de esta siempre misteriosa relación sacro-profano, él la resuelve en la historia. No es que haya que partir de lo humano para llegar a lo divino, porque están en constante tensión y relación, sino que debemos caer en la cuenta que sólo desde su existencia histórica, podemos entender su propuesta, porque precisamente su humanidad no está separada de su divinidad, su historicidad es un ejercicio de libertad responsable con Dios y el mundo. No partir de la humanidad sería negar el principio nuclear de la Revelación judeo-cristiana: la historicidad personal como experiencia vivencia del hijo que busca su madurez en la relación del mundo y Dios. En definitiva, antes de presentar los puntos concretos de la Revelación en Jesucristo, lo que quería esgrimir como premisa es que, sólo partiendo de la humanidad de Jesucristo, podemos entender su interpretación-propuesta existencial religiosa para nosotros ${ }^{151}$.

\section{B. 2 La ruptura de Jesús en la teología. Jesús, único y diverso intér- prete de Dios ${ }^{152}$}

Habiendo presentado la ruptura general de Jesús, expondré ahora que la primera separación que hace respecto de la religiosidad pagana es

${ }^{151} \mathrm{La}$ intuición no sólo de la identidad entre Crucificado y Resucitado sino de que nos abre a una concepción diversa de un Dios no al estilo pagano, sino del que mete otra lógica que es la que sugiero, la encontramos en DuQuoc, C., Gesù uomo libero. Abbozzo di una cristologia, Brescia 1974, 123: "I discepoli si attendono che il Risorto ponga la sua potenza al servizio della speranza secolare e che l'arroganza dei nemici venga annientata. Ma il Risorto non imbocca una strada diversa dal Crocifisso"; "Il Risorto no è investito della potenza di Dio per imporsi ai suoi avversari e distruggerli, bensì per suscitare dei testimoni che, come lui, rovesceranno la logica distruttrice del male mediante la sovrabbondanza del bene" (125).

$152 \mathrm{El}$ planteamiento de los dos últimos apartados sea el de la ruptura como el de la novedad, ofrecen una bibliografía conocida, pero renovada. El punto más importante es tener en consideración la plenitud de la Revelación en Cristo entendida en el sentido desde la DF, DV a la DI, pero con los matices fundamentales que hoy ofrece; en otras palabras, no es que haya cambiado la cristología dogmática, pero sí la fundamental y debemos concebir la persona de Jesús en nuestros días como el que ilumina una nueva forma de entender a Dios. Ofrezco alguna de las muchas obras que nos exponen con claridad cuál fue la 
acentuar la desacralización o, de alguna manera, una paradójica descentralización-centralización del Padre (léase divino, misterio absoluto, dios). Hoy día, para nosotros, retorna como problema vivido y pensado a nivel teológico el hecho de la problemática sobre la centralidad del Padre o de Jesucristo. Precisamente, lo que pretendo es perfilar aún más las consecuencias de volver a partir de su humanidad histórica, entendida como se ha expuesto: secular, desacralizada, responsable, etc., porque en ella se encuentra la relación humano-divina. La centralidad de Jesucristo debe ser máxima, para entender la centralidad del Padre, pero si nos olvidamos de él, si lo relativizamos, podremos andar hacia el misterio, pero nunca según la especificidad de la Revelación cristiana. He aquí, que la ruptura teo-céntrica que hizo Jesús es la misma que debemos recuperar hoy, pero no para convertirlo en un absoluto exclusivista, sino para poder mostrar la especificidad del cristianismo delante de los desafíos del nihilismo pagano postmoderno ${ }^{153}$.

Este hecho lo vemos perfectamente reflejado en el irenismo en que se cae cuando se quiere hacer una teo-logía como medio más eficaz, para un diálogo religioso que nos lleve, no sólo una mayor tolerancia y profunda búsqueda respetuosa de la verdad, sino también a una recuperación

particularidad de Jesús o del Dios de Jesús: W. KASPER, Il Dio di Gesù Cristo, Brescia 20037, 216-268; A. Amato, Gesù il Signore. 'Saggio di, sobre todo pp. 439-504.581-607; S. PIÉ-NINOT, La teologia fondamentale, Brescia 2002, 315-337.442-455. En esta última propuesta también se puede leer una rica relación actual de cómo la definitividad de la Revelación en Jesús lleva hoy día a una también definitividad, única e irrepetible revelación del hombre a la luz de GS 22. En esta línea de actualización de la cristología orientada hacia un descubrimiento de la Revelación de Jesucristo como distinta, plena y actual revelación de Dios y del hombre encontramos también R. LATOURELLE, L'uomo e i suoi problemi alla luce di Cristo; J. WICKS, La pienezza della Rivelazione in Cristo: la genesi della dottrina nella Dei Verbum e la sua riproposizione odierna, Giomata di studio 25 novembre 2000; CASTILLO, J.M.-EsTRADA, J.A., El proyecto de Jesús, Salamanca 20046.

153 Escojo dos textos del Papa Benedicto XVI para expresar, sea la importancia de considerar la inevitable relación Jesús-Cristo para la reflexión teológica, como la importancia de la historia: RATZINGER, J., Introduzione al cristianesimo, Brescia 2003 ${ }^{12}$, 161-162: "Facendo un ultimo passo avanti, Giovanni potè infine saldare fra loro i due movimenti. Il suo vangelo è quasi una lettura delle parole di Gesù fatta alla luce della persona, e della persona alla luce delle parole. Che egli faccia della cristologia, ossia attesti la fede in Cristo quale messaggio sgorgante dalla storia di Gesù, e reciprocamente ci presenti la storia di Gesù sotto forma di cristologia, è un fatto che mette chiaramente in rilievo la perfetta unità formata da Cristo e da Gesù: un'unità che è e permane costitutiva per tutta la susseguente storia della fede"; "Bisognerà quindi ribadire che la storia, intensa nel senso più stretto del termine, non solo ci rivela il vero corso delle vicende, ma assai spesso che l'occulta. Constatato questo, va da sé che essa riesce sì a vedere l'uomo Gesù, ma stenta assai a riconoscere il suo esser Cristo, che in quanto verità storica non si lascia incasellare nella documentabilità della mera esattezza di riscontro" (152). 
cualitativa-cuantitativa del cristianismo; apuntando hacia el común denominador que nos une, el discurso de Dios, y dejando más a un lado la particularidad de Cristo, será más fácil ser interpelante para la gente y recuperar nuestro puesto en el marco de la religión. De hecho enseguida captamos del ambiente que el discurso teológico aprehende palabras más generales como dios, pero sobre todo, aún más comunes (y por ello aún más vagas) como el misterio, el absoluto, la realidad última... palabras en las que todos podemos entrar y comunicar, porque nadie las puede definir y, así pudiendo decir todo, no se determina nada.

El discurso es grave, bastante más de lo que parece, por ello, aunque sea sucintamente, expondré una síntesis. El epígrafe por mí expuesto, respecto a la especificidad, es bastante discutido no sólo por todas las formas de religiosidad ajenas al cristianismo, sino también por parte de un buen número de cristianos (contaminados-contagiados del contexto de la religiosidad postmoderna, genérica y mitológica) y sectores católicos; tal vez, mencionar palabras como especificidad, único, etc. suenen a cierta pretensión de absoluto y exclusividad, pero queda claro que no es mi hipótesis. La tesis opuesta sería ésta: Jesús no puede ser el Logos, es sólo una manifestación de algo superior, una interpretación del misterio, si se quiere una manifestación de esa realidad última, incluso válida, pero no se puede identificar con la Revelación. Nótese que, sin profundizar en discusiones dogmático-teológicas, no le falta razón; incluso la teología católica puede hacer uso de expresiones similares para matizar cuestiones trinitarias muy precisas, verbi gratia, la no absoluta correspondencia con la segunda parte del axioma rahneriano (el famoso viceversa que afirmaría que la Trinidad inmanente es la Trinidad económica) o cuando queremos hablar de cuestiones referentes a la Parusía. De este modo, Jesús no puede ser la mismísima realidad misteriosa que incluso los católicos afirmamos de ese Dios trinitario que permanece en el misterio ${ }^{154}$.

Las consecuencias son inmediatas: si Jesús es sólo una representación, interpretación, manifestación más de lo sacro, pero no es una total identificación, una absoluta revelación, concluimos de inmediato que Jesús sólo es un símbolo, una expresión más de la divinidad común y misteriosa y, no sólo eso, sino además sólo válido en todo caso para un grupo determinado ${ }^{155}$.

154 Cf. PANIKKar, R., La pienezza, 197-201, donde muestra una visión alternativa sobre la no-exclusividad del conocimiento de Cristo de los cristianos; sugiere que la forma occidental de comprensión ha encasillado a Cristo, cuando no se debería temer la pérdida de la identidad de Cristo, abandonando lo específico que lo diferencia.

155 Cf. Mardones, J.M., ¿Adónde, 207-210. Desde la perspectiva holística de que la realidad es el sacramento del Misterio, por un parte no hay problema en afirmar que Jesús 
Como vemos la consecuencia es catastrófica no sólo por la relatividad ante el resto de religiones, sino porque para ese grupo determinado, los cristianos, surge una explosión interna por ese relativismo: si Jesús no es la manifestación de Dios, la Redención-Salvación no es real, como máximo sólo nos vale aprender de esa figura, emblemática no obstante, la resignación universal, la conmiseración hacia los hombres, pero la humanidad sigue tocada de muerte ${ }^{156}$. Ante esta creencia, hoy día generalizada y metida muy dentro de nuestros creyentes, sobre todo jóvenes, se dan todos los fenómenos anteriores ${ }^{157}$ : se pertenece al cristianismo, pero no hay problema en mezclar otras cosas provenientes de otras manifestaciones (creo en Cristo, pero me relaciono con él a solas, personalmente, a un modo "orientalizado"); me afirmo creyente, pero es posible renunciar a aquellas mediaciones, creencias que me parecen que no van de acuerdo con ese misterio común, con el fondo importante y auténtico de ser religioso; peregrinamos, salimos en procesión, llevo una vela a la Virgen (sólo a la mía), pero lo mezclamos con un sentimiento egocéntrico, sólo hasta que satisfaga mis emociones, compense mi vida, reestablezca mi ansiedad, haya un grupo que me afirme; o bien, al margen de la infinidad de casos que aquí podría traer, aquellos cristianos periféricos que, en efecto, se han apropiado de unos valores "culturizados" sin tener que hacer nada por ello, defendiendo que lo más importante es el hacer, la ética... nada de ortodoxia, es la época de la ortopraxis 158 .

Sin embargo, creo que hoy se puede afirmar, y se debe hacer con urgencia, la ruptura que Jesús supone a la hora de interpretar lo divino. De hecho vivimos en tiempos muy similares a los de Jesús en cuanto a religiosidad se refiere; él se encontró también en medio de una religiosidad de los filósofos griegos que seguían una tendencia religiosa externa, racio-

haya sido manifestación de tal Misterio, pero, al mismo tiempo, se le niega toda pretensión de absoluto.

156 Hoy día el discurso sobre la Salvación es el más urgente. La soteriología de hoy es muy débil, no dice nada a las personas, no convence, porque la concepción soprahistórica no es fiable. De ahí que una vía de solución sería recuperar una ligazón con la cristologíaantropología, entendiéndola desde esta perspectiva que planteo e intentando partir de los signos de salvación que emergen desde un análisis fenomenológico.

157 Cf. TORres QueIRUGa, A., Fin del cristianismo, 205-207. Plantea que se cae en esa vaguedad de Dios, que al final no se aprecia en ninguna parte o en el dios milagrero. Frente a esto su propuesta es el panenteísmo como una trascendencia que no se aparta del mundo "sino en una presencia íntima, fundante y siempre activa" (205).

158 Nótese aquí que estamos ante un comportamiento fosilizado, ya que en este caso, la persona no asume nada de una creencia, sólo tiene que "dejarse llevar" por el bagaje que ha heredado inconsciente e involuntariamente de la cultura; estamos en lo que Edgar, Schein o Lonergan llamarían el tercer nivel de la cultura: la cultura subjetiva implícita. 
nal, gnóstica... también dentro del judaísmo. De frente a este panorama Jesús interrumpe la lógica de esta religión con una existencial, antropológi$c a$, que escapa de ritualismos, gnosis, justificaciones de órdenes sociales, diferenciaciones ontológicas. Jesús inaugura una forma inédita de relación con Dios; en efecto, y he aquí el punto clave de mi reflexión, mientras la religiosidad, o diversos discursos teológicos de hoy afirman que Jesús es una manifestación más de la realidad última, una constante interpretativa de una interpretación del divino, yo sostendría que Jesucristo es una ruptura, un principio particular de la interpretación de Dios, de relacionarse con El. Repartir de Jesús es afirmar la centralidad paradójica de su ser, ya que descentró el sistema interpretativo religioso de su época, poniendo en el centro un elemento constante de crítica a la interpretación general del divino: introduce un principio que "deconstruye", reformula la idea de Dios, del hombre y la historia. Este principio particular que es la identidad del cristianismo es la paradoja de la kénosis.

Será esta kénosis la que irrumpa y rompa el sistema no sólo religioso del momento. Por eso hoy día, para nosotros también es un kairós, porque vivimos la misma situación crítica de Jesús. Dios ha vuelto a ser enfrascado en un misterio absoluto, del que nadie sabe nada, pero Jesús precisamente presenta un Dios muy concreto y muy diverso a uno difuminado ${ }^{159}$. Hoy día el sistema religioso-mítico responde a la reorganización del sistema, a la autosatisfacción, a reajustar el caos sin cuestionamientos, a justificar una estabilidad que está mucho más allá de la armonía que Dios pueda desear. Por eso Jesús fue y el cristianismo hoy debe suponer un virus en el sistema; si el cristianismo no tiene nada que decir y decae, muere en agonía, es porque funciona sirviendo al esquema apenas mencionado, es decir, con un código que le hace saltar, precisamente porque, el rol de Jesucristo y el nuestro es el de hacer saltar el sistema, porque la kénosis nos lleva a un Dios de rostro concreto, a una religión existencial, antropológica que supo-

159 Ante este panorama es difícil ver este momento de Kairós; por ello muchos libros han reseñado últimamente desde el mismo título si cabe un futuro para el cristianismo, entre los que tenemos con distintas perspectivas, pero siempre intentando recuperar este cristocentrismo con las dimensiones ya indicadas: A. TORRES QUIERUGA, Fin...; J. MOLTMANN, Chi è Cristo per noi oggi?, Brescia 1995; C. DuQuoc, Cristianesimo, memoria per il futuro, Brescia 2002; F. KAUFMANN, Quale futuro per il cristianesimo?, Queriniana, Brescia 2002; J.M. MARDONES, Síntomas de un retorno. La religión en el pensamiento actual, Santander 1999 y La indiferencia religiosa.... Por último, un libro que creo sigue muy de cerca el planteamiento de este artículo en el sentido de la interrupción única, especial que supuso-supone Cristo en la interpretación de la vivencia de Dios A. TORRES QUEIRUGA, Repensar la Resurrección: la diferencia cristiana en la continuidad de las religiones y de la cultura, Madrid 2003. 
ne un virus en el sistema general: el profetismo denunciante, el Reino de Dios que explota y emerge con definitividad como el grano de mostaza, el símbolo de la salvación que necesita ser transformado en metáforas reales y vivas del existir cotidiano, para poder sanar la humanidad, pero no justificarla ni negarla en nuestros paraísos artificiales o anestesiados con una religiosidad muerta internamente y ofensiva públicamente.

\section{B. 3 Cristo contra...}

Por fin, llegamos al intento de ofrecer alguna propuesta cristológica para nuestros días, aunque, si es ya difícil tener una mínima percepción de lo que sucede, de hacer un análisis fenomenológico, reconozco que todavía supone más el plantear un camino nuevo. De todas formas, queda claro que la ruptura debe comenzar por un reinicio desde la humanidad, la kénosis, la historicidad donde Jesús y nosotros nos jugamos nuestra existencia. He querido vincular estas cuatro breves intuiciones en el marco de lo que he denominado ruptura, porque he vinculado la especificidad de Jesús, pero siempre como ruptura de una situación.

\section{...la desigualdad 160}

Esta idea viene ligada a la ruptura con la familia, que consiste en expresar una extensión de la fraternidad como lógica del Reino. La apertura propia, intrínseca del hombre es universal y va más allá de la lógica de pertenencia a un grupo social, cultural... Fraternidad pues, no niega las relaciones familiares, sino que entiende las relaciones interpersonales de otro modo, convirtiéndose en un concepto y modus vivendi revolucionario, porque afirma la igualdad, rompiendo toda otra lógica (esclavo-patrón, hombre-mujer, raza superior-inferior...) $)^{161}$. No hay ya más genealogía, sino fraternidad,

160 Cf. CASTILlo, J.M., El proyecto, 20-22.

161 En los "inicios teológicos" del teólogo Ratzinger, encontramos un jugoso libro, cuyo título ya nos orienta a esta irrenunciable y prioritaria identidad del cristianismo: $L a$ fraternidad de los cristianos, Sígueme, Salamanca 2004 (original alemán de 1960). Allí, preservando la casi enfermiza estructura jerárquica, matiza en la introducción de uno de los capítulos: "Por encima de los necesarios límites del status o del ordenamiento jerárquico tiene que prevalecer el ethos de la fraternidad o de la igualdad" (77); pero más radical aún se nos recuerda el proyecto de fraternidad querido por Cristo, por encima de una iglesia jerárquica: tras recordar Mt 23, 8-11 (no llaméis a nadie Padre, maestro y preceptor) que, curiosamente coloca la vida sacerdotal como antítesis de su imperativo, el actual Papa dice: "Sobre todo si se aceptan los versículos 1-8 que preceden al texto anterior, se ve meridianamente cómo la fraternidad única y sin diferencias se contrapone al falso jerarquismo y al culto de las altas divinidades dentro del judaísmo... ¿No es acaso nuestra praxis cristiana 
somos hermanos del hijo y, por tanto, abre una puerta para entendernos como hermanos y hermanas. Es extender la lógica del hijo, que se hace corresponsable, cocreador en la historicidad, en la dinámica del Padre ${ }^{162}$.

\section{...la deshumanización del hombre ${ }^{163}$}

La ruptura con la ley no muestra a un Jesús anárquico, fuera de la ley, no quiere destruir el orden, sino denunciar y oponerse a ella si no deja madurar, si la relación hombre-ley deja a aquél en subordinación ${ }^{164}$. Para su época, la ley representaba la lógica de toda la existencia, regulada, pudiendo así establecer y expresar una identidad que distinguiese al hombre de los animales. El problema era que ese signo distintivo se había transformado en algo tan opresivo para el desarrollo del hombre que Jesús re-sitúa, pone al hombre en el centro, desafiando la estabilidad del sistema; aún más provocatorio se convierte, cuando esto en la práctica cotidiana modifica el sistema de Israel. Creo que aquí captamos enseguida el parangón con nuestra sociedad, donde el sistema es el que configura opresivamente al hombre y éste queda en una libertad castrada, inmadura, manipulada, cayendo además en la inconsciente afirmación del sistema que lo oprime; como en Israel, la ley que sofocaba a los judíos, era precisamente lo que ellos se cuidaban de proteger y ensalzar ${ }^{165}$.

mucho más parecida al culto a las altas dignidades fustigado por Jesús que a la imagen de comunidad cristiana dibujada por él? [...] ¿Puede algún hombre el derecho a ser considerado por otro padre espiritual?, ¿es que este derecho y honor no es exclusivo de Dios...? Hemos de añadir lo siguiente: que no sólo el título de Padre-Vater el que aquí se limita, sino que cualquier otra forma externa de jerarquismo que haya surgido a lo largo de los siglos, tiene que dejarse juzgar una y otra vez por este texto" (80-81).

Otros apoyos de textos que recuerdan la fraternidad como proyecto/ruptura de Jesús: GonZÁlez FAUS, J.I., Calidad, 276-281 y MARDONES, J.M., Matar a nuestros dioses. Un dios para un creyente adulto, PPC, Madrid 20075 , 131-153.

162 Aunque podemos extraer de cualquier manual de cristología reciente (cualquiera de los ya citados) las novedades de la vida de Jesús comparto cuatro textos con orientaciones claras y concretas de las rupturas-novedades que supuso: A. AMATO, Gesù il Signore..., 13-35.159-215. 387-581; ID., Gesú Cristo liberatore della donna, in Essere donna, a cura di M. Toso, ElleDiCi, Leumann (TO) 1989, 102-112; J. SoBRINO, Rapporto di Gesù con i poveri e $i$ desiderati, in Concilium 15 (1979) 1647-1659; A. RuBERTI, Per una cristologia dell'agire di Gesú, Bologna 2003.

163 Cf. CASTILlo, J.M., El proyecto, 17-20; AmATo, A., Gesù il Signore, 167-169.

164 Madurar el dios de la ley que deshumaniza debe consistir en la ruptura de imágenes de un Dios de la sumisión, del Dios represivo de la sexualidad o del Dios moralista: $c f$. MARDONES, J.M., Matar, 91-96.

${ }^{165}$ La actuación cristiana (su propuesta moral) debe orientarse hacia la puesta en práctica de la libertad corresponsable, creativa del hijo (algo que ninguno de los 2 hijos de la parábola del padre misericordioso entendieron). Cf. MARDONES, J.M., Matar, 103-105.110-113. 


\section{...la sacralización de Dios ${ }^{166}$}

La ruptura con el culto nos tiene que llevar a esos pasajes del estilo de la samaritana, recordándonos que el verdadero culto es en espíritu y en verdad167. He aquí la interpretación de la relación con Dios inaugurada por Jesús y vigente como "anormal" hasta nuestros días. Precisa y paradójicamente tenemos en Jesús al primer desacralizador del culto, no hace falta esperar al iluminismo, ni al personalismo del siglo XX, porque Jesús, si relativiza el culto es en función de un existencialismo-antropológico, como diríamos hoy, quitando la absurda e inútil máscara sacral (como ya he mencionado el alto porcentaje de nuestra liturgia, podemos extender a la experiencia cristiana en general, responde a esa ritualidad mágica, comenzando por la Eucaristía) ${ }^{168}$. Tal vez hoy día, podríamos reinterpretar el pasaje de la expulsión de los mercaderes del Templo con nuestras propias eucaristías o rituales vacíos... tal vez nuestra aproximación al misterio a través de nuestros sacramentos están siendo un insulto al Dios vivo. La desacralización de Jesús inaugura una forma inédita de relación con Dios. He aquí nuestro gran kairós, interrumpir la vivencia actual de la relación con Dios... sin darnos cuenta hemos encerrado en vacíos contenedores la vida de Dios, el rostro de una divinidad cercana, histórica, que se da al hombre, para que éste se dé en sus hermanos, para que el culto se ordene al Dios de la vida, de la creación y, por tanto a la creación misma, y no que permanezca en el culto mismo. La modernidad ha sido capaz de recuperar este sentido "desacralizante", pero lo ha llevado al otro extremo, deshumanización.

En este momento podemos tener toda la panorámica del planteamiento que arrojo en estas páginas, porque ahora se puede entender qué

166 Cf. CASTillo, J.M., El proyecto, 22-26; Amato, A., Gesù il Signore, 177-179.

167 Es una de las consecuencias de haber perdido la dimensión del Reinado de Dios, diluyéndonos en una mera religión o religiosidad que poco tiene que ver con la fe como modo-de-ser-en-el-mundo personal y personalizante ( $c f$. GoNZÁLEZ FAUS, J.I., Calidad,275ss). Uno de los imperativos del Reinado de Dios es que, la fe, se vịve en la historia, en la vida in-corpor-ada, en-carn (e)-ada y no en el culto: "Dada la preponderancia del culto y de la mal llamada sacramentalización en la forma actual del cristianismo, los cristianos habrán de recordar que lo que llamamos culto no es una necesidad de Dios, sino una necesidad nuestra, y no aporta nada a Dios, sino que debería aportárselo al hombre...por eso mismo los cristianos del mañana deberán tener mucho más cercanos y conocidos los textos del Antiguo Testamento que son conocidos como crítica del culto (y que constituyen la línea veterotestamentaria donde más se inserta Jesús): "odio vuestros sacrificios y me aburren vuestras ofrendas"; o "el ayuno que Yo quiero es que partas tu pan con el hambriento"; o "si necesitara algo, ¿crees que tendría que pedíroslo a vosotros?” (276-277).

168 Hay que recuperar el Dios de la vida y festivo en nuestras celebraciones y escapar del Dios de los sacrificios rituales y mágicos: $c f$. MARDONES, J.M., Matar, 77-83. 
significa actuar con otros mecanismos ajenos al cristianismo: Jesús y nosotros vivimos en un tiempo en el que la religiosidad es una externa, de la demanda, de la estabilidad o bien, como tan difundido es hoy y entonces por los griegos, se opta por una vida feliz sin Dios dentro de los límites de la existencia, donde, por supuesto, el criterio del antropo-egocentrismo es idéntico a la primera opción. Ante esto el cristiano hoy tiene que interrumpir la manera de relación con Dios, alejándose de un culto vacío y de un cultocentrismo, siendo conscientes que por fortuna, después de 2000 años, tenemos una religiosidad original cristiana completamente por descubrir y vivir.

\section{...la religión civil 169}

La ruptura con el nacionalismo por fin es con aquélla de una concepción civil de la religión. Lejos de separar la religión de lo civil, de su implicación político-cultural, cosa que negaría todo lo expuesto hasta el momento, lo que propone la vida de Jesús es una total inmersión en la cultura para acercar la vida de Dios al hombre, pero manteniendo una distancia prudente y necesaria, precisamente para interrumpir la dinámica de la estabilidad, del ego, de la demanda y la injusticia, para realzar la dimensión profética, la encarnación de unos valores del Reino fundados en la opción por un Dios que se hace kénosis.

\section{LA VIDA DEL JESÚS PREPASCUAL NOS REVELA Y EXIGE UN DIOS DIVERSO Y CONCRETO}

La revolución del Dios Abbá. Lo que Jesucristo ofrece...

Finalmente llegamos al gran desafío de ofrecer un camino abierto, unas intuiciones por las cuales el cristianismo, de una parte pueda entrar en un diálogo con los fenómenos que lo rodea y, por otra, exponer un programa original, radical, auténtico con su núcleo. Ya he mencionado que, delante de un mundo paganizado, el cristianismo en España no puede seguir cayendo en la lógica de la comodidad, de la sacralización de la existencia en ritos vacíos, sino que debe volver a sus raíces más proféticas, denunciantes desestabilizadoras, precisamente, como he tratado en este capítulo, porque su esencia secularizante le lleva implicarse en el mundo.

Pero me gustaría, antes de concretar mi sucinta exposición, extender un poco más lo que, para mí, es el núcleo original y singular de la Reve-

${ }^{169}$ Cf. CASTILLO, J.M., El proyecto, $65-68$. 
lación de Cristo: si ya para autores como Gogarten, queda claro que la comprensión de ser hijos es fundamental en la dinámica del descubrimiento de nuestra vocación histórica, yo diría que podemos afirmarlo, porque Jesús ha interpretado a Dios como $A b b a^{170}$. Efectivamente, ser realmente hijos sólo nos puede venir de la conciencia de que Dios es Padre, Papá de todos y que viviendo la distinción en la correlación y corresponsabilidad, adquirimos nuestra máxima vocación ${ }^{171}$.

El modelo hermenéutico de Jesús nos sirve no sólo para entender cómo él interpretó la relación con Dios, sino el divino con el profano, la historia de la Salvación con la historia, los hombres con Dios. Así pues, no queda como un modelo extrínseco, inalcanzable extraño a los creyentes de cualquier tiempo, sino que supone la inauguración de una forma hermenéutica; es decir, no podemos vivir nuestra existencia, sin interpretar y, no podemos alcanzar nuestra vocación hermenéutica, sino en la dinámica de la profundización de Dios como Padre, que nos garantiza nuestra condición de hijos y, por ello, seres libres, creativos y responsables. Sólo entendiendo la pieza clave, el signo distintivo de la Revelación de Jesús, podemos desarrollar nuestra madurez como cristianos. Así pues toda propuesta concreta que exhibiré, tendrá como telón de fondo esta esencia herme-

170 Precisamente, González Faus da la pista para ver cómo la categoría $A b b a ́$ es la que da unidad a la discontinuidad entre el Reino de Dios presenciado y anunciado por Jesús y la Resurrección anunciada por las primeras comunidades. Centrándonos en el concepto Abbá podremos recuperar el Dios encarnado y liberador del Reino, sin tener que excluir o desdeñar el primer (y casi totalemente genral-actual) anuncio de las comunidades cristianas. Este Dios en continuidad es el que va a mostrar la conflictividad, novedad y diferencia respecto de cualquier otra confesión. GonzÁlez FAUS, J.I., Calidad, 22: "En suma, en la medida en que el binomio filiación-comunión (como resultado de la continuidad entre el Jesús terreno y el Exaltado) resume y unifica la predicación plural de la Iglesia primitiva, ese binomio empalma con el otro de $A b b a ́-R e i n o$, que resumía la predicación de Jesús. La poca explicitación de Dios en el lenguaje de Jesús (en el sentido del padre de Ignacio Ellacuría que citábamos al comienzo de este capítulo) o la horizontalidad del mensaje de Jesús no implican un Dios lejano o una secularización como la que parece darse en el judaísmo de su tiempo, quizá como efecto de tanta insistencia en la Trascendencia y el respeto a Dios (v. gr. no pronunciar Su Nombre, etc, etc.). Al contrario, Dios está enormemente cercano, como animando todo el cuerpo histórico de la vida de Jesús.

Y esto va a darnos la primera sorpresa: porque a la cercanía de Dios parece seguirle inevitablemente la conflictividad de Dios".

171 Y ser hijos no entendido a la manera de una difusión-confusión espiritual, sino, como escribe PANIKKar, R., La piennezza, 156: "Per diventare figli di Dio, come Gesú, non dobbiamo disumanizzarci con ascetismi negativi, abandonando il corpo e la materia, come ci suggeriscono tante spiritualità neoplatoniche, vedantiche e via dicendo. La theosis cristiana non è la fuga del solo verso il Solo, ma la piena realizzazione del caro factum est [si fece carne], cioé l'Incarnazione. 
néutico-secularizante que nos hace gritar $A b b a ́$ y que nos exige una vida cocreadora y libre en el mundo.

\section{Propuesta antropológica. Diferente manera de relacionarse con los demás}

Es cierto que el hecho de la especial atención que Jesús puso en las relaciones con los demás, es un discurso bastante asimilado, especialmente con los que pudieran estar más desfavorecidos. Desde la actitud de perdón y conversión con los enemigos hasta la atención especial por los pequeños y débiles, vemos cantidad de matices, por los que podemos considerar a Jesús como un extraño en su modo de relacionarse ${ }^{172}$.

Efectivamente la urgencia por tener encuentros de salvación con los demás es uno de nuestros puntos débiles. Cuando Jesús se sienta a la mesa con los pecadores, busca a los enfermos, a los marginados, perdona a quien le persigue, contagia la vida de la Revelación ${ }^{173}$. Es decir, a través de su actitud, de su ética, existe una cierta correspondencia con la Revelación de lo que Dios es, o sea que, a través de las acciones, no sólo están las acciones mismas sino que emerge algo más ${ }^{174}$. Por tanto lo que sugerimos

172 Amato, A., Gesú il Signore, 176-177.

173 VIDAL, S., Los tres proyectos de Jesús y el cristianismo naciente. Un ensayo de reconstrucción histórica, Salamanca 2003,255, la idea que expongo coincide con la que de inmediato propondré a nivel litúrgico según la teología de Vidal, según el cual el proyecto de Jesús es uno que se empeña en la acción concreta histórica en el mundo y no propone, como la religiosidad de nuestros días, una "salvación de tipo automático o mágico".

174 BLONDEL, M., La acción. Ensayo de una crítica de la vida y de una ciencia de la práctica, BAC, Madrid 1996, XXX, donde César Izquierdo en la Introducción explica uno de los centros de la filosofía de la acción blondeliana sobre la distancia que existe entre el hecho, el fenómeno y lo que nosotros creemos que hacemos o queremos: "En la desproproción, afirma Blondel, entre la voluntad que quiere (volonté voulante) y la voluntad querida (volonté voulue) reside la causa que da lugar a todo el movimiento de la acción. La voluntad que quiere es puro querer de todo lo posible, es ilimitada en sus aspiraciones, está dotada de un impulso que no se aquieta con nada que no sea total, pleno y definitivo. La voluntad querida, por su parte, es lo fáctico, el modo concreto como se ha encarnado en cada caso el empuje y la aspiración de la voluntad que quiere. Entre el hacer y el querer que caracterizan a estas dos voluntades hay un desequilibrio constante e inevitable, porque nunca el hacer de la volonté voulue es la respuesta exacta al dinamismo de la volonté voulante. Este desequilibrio entre lo querido y lo hecho, entre lo posible y lo real, es el motor del dinamismo de la acción". O Isasi, por su parte, ibid. LIII: "La acción es la fecundidad inagotable y la riqueza infinita de la vida, que no es igualada jamás por el conocimiento que tenemos de ella. [...] La filosofía tiene por función determinar el contenido del pensamiento y los postulados de la acción, sin jamás suministrar el ser cuya noción estudia, sin abarcar la vida cuyas exigencias analiza, sin bastar a aquello cuyas condiciones suficientes determina, sin realizar siquiera lo que debe afirmar que concibe necesariamente como real". 
también es una cristología de la acción, entendida no sólo cómo el análisis ético de Jesús ni como la oferta de un programa de acción, sino como la que entiende que a través de la vida de Jesús se manifiesta una forma, una hermenéutica de comprender la realidad, la historia, la persona, el mundo, Dios ${ }^{175}$.

De este modo, analizando los pasajes evangélicos de los encuentros de Jesús con las distintas personas ( $M c$ 2, 15-17; $M t$ 9, 10-13; Lc 5, 29-32) que se hallan en su camino, leemos no una mera actitud revolucionaria, sino un kairós revelativo para la persona. Esta es la propuesta antropológica para nuestros días: nuestro carácter constitutivo relacional debe estar ordenado para que el otro descubra su identidad, para que el otro desarrolle su vocación, para que la descubra. En este sentido entiendo momentos de salvación, porque llevan a descubrir al otro su condición de hijos, de seres libres y responsables, de coparticipación histórica.

Es evidente que si pensamos en nuestros colegios, parroquias o las relaciones cotidianas que acontecen en nuestros hogares la realidad está muy lejana. La calidad distintiva de nuestros encuentros con los demás debe diferenciarse en estos flashes liberadores. Nuestros jóvenes no deberían gozar sólo de un buen profesorado, de alternativas deportivas, culturales, litúrgicas, sino de encuentros personales y personalizantes. "Perder" el tiempo con ellos, acompañarlos en sus realidades (si Jesús fue criticado como borracho por comer en la casa de los pecadores, puede que nosotros deberíamos ser criticados por filtrarnos en lo que en la primera parte denominé sus templos; pero para ser criticado, antes hay que actuar...), no asépticamente, sino para que, viviendo entre ellos, descubran la diferencia ${ }^{176}$.

\section{Propuesta sociológica}

El descubrimiento de la intrínseca dimensión antropológica del cristianismo no debe ni puede quedar en la improvisación o en atenciones personales, porque se corre el riesgo de la justificación de muchas injusticias. No puede quedar como un planteamiento ético personal, que actúo con quien

175 BLondel, M., L'azione, 1993, 77: "Bisogna trasferire nell'azione il centro della filosofia, perché là si trova anche il centro della vita.

176 Cf. LATOURElle, R., L'uomo, 271-291.309-338, nos muestran un ejemplo de cómo el repensar la Revelación debe estar dirigido hacia la resolución de los problemas de la persona; trabajo, progreso, soledad...que hoy se trasforman en otros problemas y, por eso, la Revelación debe ser reinterpretada. He aquí el sentido de $G S 22$, porque sea el hombre que la Revelación están en una constante dinámica relación y por ello (relación que se desarrolla, se desvela, continua) es necesario que cuando se reflexione de uno de los dos, se haga obligatoriamente del otro. 
está a mi alcance, porque somos conscientes de que el sistema consiente a nivel globalizante muchos encuentros no liberadores, descubridores de la identidad de la persona, sino más bien devastadores, deshumanizante.

Por tanto, es precisamente la propuesta antropológica la que nos descubre y exige la sociológica. Debemos pensar en proyectos comunes hechos desde y para la comunidad-sociedad. Precisamente, porque mi hermano no es el cristiano, sino, sobre todo el pobre, es quien debe motivar la urgencia de estos proyectos ${ }^{177}$. En toda la reflexión teológica está presente esta idea de la prioridad por los pobres, porque una sociedad que permite estructuralmente, que la persona no descubra y, en consecuencia, no realice su vocación está andando contra el proyecto del Reino'i78.

El encuentro con el samaritano ( $L c 10,29-37)$ es nuestro referente en este caso. No es la religión ni la nacionalidad lo que hace al otro hermano, sino su condición de hijo; pero es más, la revelación del Dios $A b b a ́$ es quien los une en esta relación que no puede ser sino necesaria. El pobre como hijo me hace descubrirlo como hermano; mi vocación idéntica de hijo es lo que me hace encargarme de él. Jesús en su relación con los demás nos ha mostrado nuestra máxima vocación que es la vida trinitaria: vivir en la necesaria relación, nuestra diferencia. Pero esa relacionalidad intradivina, él nos la ha hecho entender a través de su histórica relacionalidad y, por tanto, la exigencia de una vida justa, nace de la esencial comunión a la que somos llamados.

Tal vez a nivel concreto, el cristianismo ha sabido y sabe hacerse presente entre los pobres. Reconociendo, pero poniendo al mismo tiempo los excesos aparte, el cristianismo ha sabido promover esa dimensión. Tal vez, el problema que se debería resolver es integrar esta prioridad existencialteológica en el discurso cristiano general. Según mi punto de vista, parece quedarse como la labor marginal de unos misioneros y voluntarios, aparte de un relax de la conciencia moral del que practica la limosna en estas iniciativas. La propuesta pues, no sólo es la de hacer acciones concretas dirigidas hacia la construcción de una nueva humanidad, de un proyecto sociológico diverso, sino de entender que esta dimensión nace de la propia esencia de la Revelación. Un Dios Abbá que revela al hombre su máxima vocación, ser y vivir (aunque no habría diferencia) como hijo, nos tiene que revelar al mismo tiempo que en el pobre está la primera urgencia de la sociedad, por-

177 Cf. GonZÁlez FAUS, J.I., Calidad, 64-70; la encarnación debería suponer la identificación de Dios con lo más bajo y excluido de este mundo en sus múltiples formas.

178 Cf. Mardones, J.M., Postmodernidad, 140-144. 
que se le está impidiendo vivir como hijo, porque no tiene los mínimos presupuestos para poner en práctica su libertad responsable.

\section{Propuesta política ${ }^{179}$}

Tal vez siempre ha sido un punto peliagudo hablar de la religión y la política, pero para la Revelación cristiana hay un reclamo necesario ${ }^{180}$. Ya en el apartado anterior he expuesto el contraste de Jesús con la Ley, pero aquí querría explicitar alguna idea más. Jesús no sólo criticó y cuestionó, hasta el fin de negarla y no cumplirla, la ley mosaica $(M c 1,4 ; M c 3,1-5$; Lc 13,10-17; 14, 1-6; Mt 8, 15; 14, 36, 20,34), sino que fue contra las instituciones concretas de Israel ${ }^{181}$; no en vano, debemos recordar la dimensión política de su muerte. ¿Debemos ir en contra de la política? ¿Es la esencia de nuestra vocación cristiana182? Ciertamente no. Que Jesús muriera condenado no sólo por cuestiones religiosas no quiere decir que viviera como proyecto ir en contra de la política, sino que, una vez más, su vocación plena de hijo, le llevo a ser coherente ante una política, unas instituciones que impedían descubrir la autenticidad de la persona ${ }^{183}$.

Como ya queda dicho, cuando la ley, la política está por encima de la persona, de tal forma que la manipula y la asfixia, la persona sufre el velo de la realidad y le impide descubrir su proyecto. Hoy día vivimos en idéntica situación que entonces, es más con una abierta controversia anticristiana (más anticlerical), reclamando la dimensión individual de la religión. Creo que queda suficientemente ya expresado a lo largo de mi reflexión que la naturaleza profética, nacida de la categoría de la filiación, no puede entrar ni en el absentismo pagano ni en la demagogia y engaño político ${ }^{184}$.

179 Cf. CASTILlo J.M., El proyecto de Jesús, 17.

180 Cf. MARDONES, J.M., Recuperar..., 65-70. El autor expone con objetividad cómo la esencia de nuestra Revelación en Cristo exige e implica una necesaria dimensión política, no entendida como objetivación o concretización en un partido político, sino como el hacerse anunciante de unos valores sociales y denunciante de las injusticias que van en contra del proceso de humanización de la persona inserta en un proyecto socio-político común.

181 Cf. CAstillo J.M., El proyecto de Jesús, 18-19.

182 Cf. MARDones, J.M., Recuperar..., 79-80, nos recuerda el problema de la identificación de cualquier propuesta religiosa-política concreta con el designio de Dios que en tantos fanatismos ha desembocado, cuando se han teologizado las ofertas políticas.

183 Cf. MARdones, J.M., Recuperar..., 106-117, el autor, siendo fiel a la esencialidad histórica, personal del cristianismo, no sólo afirma la recuperación del discurso político por la justicia, sino que expone exigencias concretas para la sociedad de hoy entre las cuales tenemos la pobreza, desigualdad, injusticia, la emigración, la mujer, la política y el consumismo.

184 SCHILLEBEECKKX, E., La questione cristologica. Un bilancio, Brescia, 19852, 64: "Il problema che il interesse teologico solleva sul Gesù storico ha avuto, tra l'altro, per conse- 
El cristianismo está llamado a ser político ${ }^{185}$ por su esencia secular, por su condición histórica y siempre que exista un hermano privado de esta condición, el cristianismo debe saltar como virus en el sistema ${ }^{186}$.

A este punto, cualquier cristiano como perteneciente a la sociedad política debe cuestionar programas $\mathrm{y}$, sobre todo, prácticas políticas deshumanizantes, pero, sobre todo, deben ser los políticos cristianos ${ }^{187}$ los que saquen la cara y sean fieles a sus ideales profundos hasta el nivel de tener que presentar una dimisión, por consentir propuestas contra la dignidad de la persona ${ }^{188}$.

\section{Propuesta teológica ${ }^{189}$}

Fundamentalmente es el gran problema. Queda más que clarificada que la propuesta más necesaria es la de la concepción teológica, no tanto en cuanto teorización, sino como las repercusiones a nivel existencial. Toda mi argumentación versa sobre la confusión, ya desde los orígenes y épocas anteriores del cristianismo, que se ha experimentado a nivel de la reflexión y la experiencia vivida entorno a la concepción de Dios. Pienso que, precisamente por la misma condición antropológica, por la misma incapacidad existencial de plenitud, la concepción y experiencia de la religiosidad pagana, omnipotente y separada del mundo, garante de la tran-

guenza la rivalutazione teologica della vita profetica di Gesù, del suo messaggio e della sua conseguente prassi di vita, dove la morte e risurrezione di Gesù non vengono formalizzate in modo kerygmatico". Con este texto Schillebeeckx resalta el centralismo de la vida profética de Jesús, incluso como clave hermenéutica que centra la atención sobre la praxis de Jesús más que en su resurrección.

${ }^{185}$ Aparte del gran punto de referencia a Metz cito un ensayo que reivindica la esencia política del cristianismo: ARENS, EDMUND, "Nuovi sviluppi della teologia política" en Gibellini, R. (ed.), Prospettive teologiche per il XXI secolo, Brescia 2003, 86: "La teologia politica è pubblica. Essa si concepisce in tre realtá pubbliche, si forma e si articola in relazione ad esse. Le tre grandezze di riferimento rilevanti per la teologia pubblica sono in primo luogo la scienza, in secondo luogo la chiesa e, in terzo luogo, la societá.

186 Baste recordar la bellísima expresión de Balthasar (el sacramento del hermano) que encontramos en su libro Sólo el amor es digno de fe, Sígueme, Salamanca 2004.

187 Cf. MARDONES, J.M., Recuperar..., 51: "No pidamos que la estrategia desde arriba. Si exigimos voluntad política al G-8 para que imponga un control sobre los mercados financieros y evite los desequilibrios sociales a que dan origen, empecemos también por nuestro municipio, ayuntamiento, autonomía y nación, pidiendo que las políticas sociales se adecuen a las necesidades de los ciudadanos."

${ }^{188} \mathrm{DH} 2 ; \mathrm{GS} 16,17,21,28,39,46,51$.

189 Recalcar la necesaria recuperación del proyecto mesiánico del Reino de Dios: $c f$. VIDAL, S., Los tres proyectos de Jesús y el cristianismo naciente, Sígueme, Salamanca 2003 y Jesús el Galileo, 107-140; GonZÁLEZ FAUS, J.I., Calidad, 185-225. 
quilidad de la humanidad, se ha dejado aparte, cuando no se ha negado la Revelación específica de Jesucristo.

$\mathrm{El}$ problema es que el resto de las propuestas o reflexiones teóricas, carecen de fundamento, si simplemente creemos que la condición hermenéutica y secularizante son sólo dos apéndices más sobre la reflexión cristológica. Es decir, afirmar que aquéllas no son esencialmente cristianas quieren decir que son criterios válidos para un tiempo, negando lo que yo aquí quiero decir. Toda reflexión sobre Cristo debe partir desde esa condición desacralizada de la religión, de la experiencia del divino y del mundo. Jesús no ha continuado con una cosmovisión existencial pagana, sino que ha metido la dinámica de la salvación en la historia y la ha sometido a proceso hermenéutico, de interpretación, subrayando que a través de la libertad y responsabilidad cocreadora, podemos vivir la madurez existencial.

Es fácil, llegados a este punto, entender que las críticas contra el templo, contra la religiosidad separada de la vida, las oraciones públicas, etc. que hizo Jesús son la denuncia de un Dios que no intercepta la vida y que justifica tu situación con pequeños enganches rituales. Hoy debemos hacer el mayor esfuerzo por recuperar la dimensión específica de Jesús: una religión existencial personal, que se hace historia y vive la responsabilidad cotidiana.

Traigo a colación una vez más la parábola del buen samaritano ( $L c$ 10,29-37), para entender el tipo de religiosidad propuesta por Jesús. No es casual que no fuera ni un sacerdote ni un levita, sino lo que llamaríamos nosotros un laico de otro tipo de religiosidad y procedencia, sea el modelo elegido para ser el sacramento, la agapefanía del prójimo. No podemos dejar pasar desapercibidos los pasajes en los que Jesús manifiesta la centralidad del ser responsable del otro, del hacerse prójimo como suprema manifestación de Dios ${ }^{190}$.

Hoy día, en consecuencia como ya expresé anteriormente, la reflexión teológica debe partir de una necesaria cristología del bajo, atenta a la historicidad de Jesús, para llegar a la reflexión sobre Cristo, abierta a captar el discurso sobre la humanidad, para entender su divinidad, porque el espacio de la divinidad, nos ha dicho Jesús, es la historia concreta y particular. Por tanto todo intento por profundizar la verdadera humanidad de Jesús como un hermeneuta de Dios, como un desvelador del misterio a través del misterio de la historia concreta personal, de los hechos cotidia-

190 Cf. MARDONES, J.M., Recuperar..., 67, donde nuestro autor nos hace una relectura del samaritano en esta línea de la desacralización en un código de la caridad política. 
nos, de las interrelaciones nos llevarán a una teología más adecuada y fiel al mensaje central de Jesucristo.

Creo que también, aparte de la reflexión teológica, deberíamos priorizar con urgencia una desacralización, secularización práctica de la vidaexperiencia cristiana. Jesús intentó mostrar el segundo plano del Templo, la relativización de la vida sacerdotal-levítica (él no fue uno de ellos) y los rituales. De hecho, la celebración de la Pascua, supuso un esfuerzo por alejarse de una ritualidad mágica, para acercarse a una existencial como diré de inmediato. Nosotros, sin embargo, tras dos mil años hemos re-cubierto, re-sacralizado el esfuerzo de Jesús, hemos hecho la contra-interpretación de su mensaje. Para intentar ser fieles a su evangelio lo hemos custodiado en patrones religiosos, hipersacralizados, hemos caído en una ritualización excesiva, además privado del sentido original, incluso, me atrevería a decir, hemos configurado una vida religiosa-sacerdotal excesivamente desmesurada infiel al sentido original. Una propuesta concreta sería hacer un esfuerzo fuerte para recuperar sobre toda la dimensión laical de la vida religiosa y sacerdotal; las distinciones de pertenecer al mundo o no son una especie de blasfemia o, al menos, infidelidad al núcleo de la Revelación. Nuestra vida cristiana se juega en el mundo y somos esencialmente laicos, pero, precisamente por nuestra naturaleza secular, mundana somos divinos; basta examinar muchos casos para entender que el fracaso de la vida religiosa-sacerdotal se debe al olvido por desarrollar su naturaleza secular, por dejar aparte una plena integración en la vida, en la experiencia normal (ya desde la formación se ve la gran falta de respuestas humanas, usando razonamientos que fatigan, que, aun con la fe, no conectan con la experiencia humana, cuando no se llega incluso al recurso de la sublimación de valores como explicación del absurdo de ciertas elecciones de vida). Querer distinguir todavía dos mundos hoy día significa anular la raíz existencial histórico-secular de Jesús ${ }^{191 .}$

...No puedo cerrar este apartado de renovación teológica, sin expeler la perentoria necesidad (entre otras muchas) que el Vaticano II puso en el tapete del juego eclesiástico sobre la formación teológica: si quere-

191 Cf. MARDONES, J.M., Recuperar..., 97-105. Aunque pudiera parecer increíble esta idea expuesta por Mardones sobre la necesidad de recuperar la espiritualidad de la encarnación por parte de la Vida Religiosa, deberíamos recordar que el Magisterio en al Vaticano II estaba ya sugiriendo esto (cf. 98-99) en la Perfectae Caritatis 2: "promuevan los institutos entre sus miembros el conocimiento debido sobre las condiciones de los hombres y de los tiempos y sobre las necesidades de la Iglesia". Tal vez deberíamos llenar de concreciónencarnar tantas palabras vacías. 
mos que haya una mayor densidad teológica en el Pueblo de Dios hay que "obligar" a los fieles (esto no es imponerles nada...la imposición es a los clérigos para que promocionen el estudio, madurez y autonomía de los laicos y no su necedad, ignorancia, dominio moral y doctrinal... amén). La GS 62 MANDA: "Mas aún, es de desear que numerosos laicos consigan formación adecuada en las disciplinas sagradas y que no pocos de entre ellos cultiven estos estudios ex professo y profundicen en ellos"...cualquier comentario devaluaría el texto.

\section{Propuesta profético-hermenéutica}

Parece que es imposible escapar del discurso filosófico hermenéutico, pero, en realidad, el cristiano, no puede hacer otra cosa, porque para lo que nos ha servido es, para redescubrir nuestra esencia hermenéutica. El mensaje de Jesús es uno que está llamado a ser reinterpretado históricamente haciendo experiencia a través del evento originario a través de los testimonios ${ }^{192}$.

Por una parte, como método preciso, yo sugeriría una adecuada recuperación del discurso metafórico ${ }^{193}$. Ya he mencionado que la centralidad del mensaje del Reino, en parábolas y acciones, pierde fuerza si no insistimos en la profundidad del discurso parabólico-metafórico. Jesús, aparte de recurrir a un lenguaje sencillo, con una simbología cercana y comprensible, abre, con el discurso metafórico, una nueva lógica de comprender la existencia. Todo encaja: una comprensión del mundo que entiende que humanidad y divinidad, que presencia y misterio viven juntos, debe buscar un lenguaje sugerente, que abra a la realidad, que la intuya y no la cierre, porque la plenitud de la vida, sólo se puede coger en los hechos concretos de la experiencia histórica y, a la vez que intuimos, percibimos y acogemos, entendemos la distancia que hay entre nosotros y tal plenitud. Toda revelación es una ocultación.

\footnotetext{
192 Pié-Ninot sintetiza la idea de la necesidad del testimonio como acceso o, en palabras suyas, invitación a la fe. Testimonio y fe, como se ve, se exigen mutuamente. $C f$. PiÉNINOT, S., La teología fundamental, 658-660.

193 Sobre todo por la capacidad de dar nuevas configuraciones de sentido a la realidad, de redescubrirla, develarla de nuevo; Ricoeur, P. "Poética y simbólica", en P. Ricoeur, Educación y política, Buenos Aires, 1984,24: "el lenguaje poético tiene en común con el lenguaje científico el no alcanzar la realidad sino a través del rodeo de una cierta reacción inflingida a la visión ordinaria y al discurso ordinario que la describe. Al hacer esto... apuntan a un real más real que la apariencia... el sentido literal debe frustrarse para que el sentido metafórico emerja, de igual manera la referencia literal debe hundirse para que la función heurística cumpla su obra de redescripción de la realidad".
} 
Por tanto, es necesario recuperar o crear un lenguaje creativo, sugerente, que sea capaz de abrir la realidad y aproximarnos al evento Jesucristo, alejándonos de afirmaciones clásicas que parten de tantos presupuestos u ontologías altísimas que no se centran en la manifestación histórica y personal de nuestra religión ${ }^{194}$. Una sana fenomenología, sobre todo a partir de lo que manifiesta, expresa, sugiere la persona, nos debe llevar a la apertura al fundamento, a la experiencia de lo divino, porque la experiencia cotidiana, la humanidad misma expresa la tensión hacia ese algo más, encierra una profundidad que se deja ver ${ }^{195}$.

Debido a esto propongo ese profetismo-hermenéutico, porque por una parte, nuestro mensaje debe ser denunciante en la medida en que se opone a la vocación histórica de la persona; pero por otra, no puede entenderse como absoluto y descalificante, porque la radicalidad del profetismo radica en ser fieles a la condición hermenéutica. Por eso, podemos afirmar que escapamos de un pensamiento fragmentario entendido como relativismo, como renuncia a la experiencia madura entre humanidad y divinidad. Toda experiencia de libertad corresponsable, es decir, todo momento de la existencia es una manifestación de la divinidad, de la realidad. Pero, asumiendo que el pensamiento, la realidad es fragmentaria, debemos caminar con prudencia y humildad, porque la lógica del Reino nos manifiesta la tensión de la vida misma: algo en expansión que se deja intuir, pero no encerrar ni menos formular. De ahí que nos hallemos en la tensión entre un profetismo denunciante, que escapa de la fragmentación como relativismo que permite la deshumanización, y una hermenéutica humilde, que no es capaz de reducir el misterio, Dios a una propuesta concreta $^{196}$. Es más, una urgencia para nuestra teología es promover un discurso soteriológico, una concepción de la salvación, que pueda decir algo al hombre concreto aparte de que al final Dios nos dará la vida eterna.

194 Cf. MARDONES, J.M., ¿Adónde, 204-205; TORRES QUEIRUGA, A., Fin del cristianismo, 60-91; MARDONES, J.M., La vida, 256: "En un momento en que se vislumbra la emergencia de un nuevo paradigma de la racionalidad, debemos impulsar y estimular una razón no unilateral, abierta a lo simbólico, enraizada en el mundo de la evocación y la corporeidad, consciente de su relación constitutiva y vital con la tradición, y sensible a la alteridad de la interpretación del Otro en el rostro humano de las víctimas de la historia". 375-398.

195 Cf. SEQueri, P., Il Dio affidabile. Saggio di teologia fondamentale, Brescia $2000^{3}$,

196 La base teológica del Dios cuya comunión escatológica es la recapitulación de todo lo creado debe pasar por el compromiso cristiano de adaptar "lo cristiano y lo humano" por una parte, e integrar, por otra; por la exigencia de un cristianismo cultural pluriforme: $c f$. ESTRADA, J.A., El cristianismo, 376-385. 
Por eso, sin querer hacer un apartado aparte, también el cristianismo, fiel a la experiencia de Jesús, debe hacer una propuesta estética, que sepa intuir el divino y manifestarlo en otros moldes ${ }^{197}$. La poesía, el arte, la música... abren las puertas a los vestigios de Dios ${ }^{198}$; tantas composiciones, obras de arte, melodías nos han aproximado más a Dios que profundas teologías. Debemos intentar integrar este versarse Dios en la historia en sus diversas mediaciones y expresiones; sin duda, la exigencia de Pablo VI sobre la necesidad de que el cristianismo se transforme en cultura aún está lejana de la práctica ${ }^{199}$.

\section{EXCURSUS}

\section{El lenguaje de Jesús vs. el lenguaje de la Iglesia 200}

Como punto complementario y dedicado a la Teología fundamental, me parece urgente resaltar que uno de los problemas del fracaso del cristianismo radica precisamente en haber perdido la originalidad de la Revelación. En todo el proceso global de la Tradición, entendemos cómo sólo a través de la Iglesia, de los testimonios de fe concretos se puede reci-

197 Aparte del tomo IV de la Teodrammatica de Balthasar, el libro entero de Sequeri y gran parte de sus colegas en Milán tienden a esta perspectiva de la teología estética.

198 Como expone Vattimo es el misterio el que acomuna la diversidad de accesos a él, sin poder no absolutizarlos ni excluirlos; VATTimo, G. (comp..), Filosofía y poesía. Dos aproximaciones a la verdad, Barcelona 1999, 12: "De modo que el nexo entre poesía y filosofía se rastrea no en la indigencia histórica del pensamiento, que naufragaría en una literatura, a la cual por otra parte calumnia, considerándola como mera futilidad o anécdota existencial, sino más bien en el misterio, que mancomuna este múltiple poiein, para el cual pensar y poetizar exigen un construir, que es al mismo tiempo retomar el viejo sendero e instituir a priori (pero siempre a partir de las huellas predeterminantes) un tejido de versos o de argumentos".

${ }^{199}$ Seguimos cayendo en el drama denunciado por Pablo VI en EN 20.

200 Este breve apartado no sólo quiere reflexionar sobre la gran diferencia entre el lenguaje parabólico y el dogmático, es decir, como mera cuestión formal, sino, especialmente, sobre la pérdida de la predicación de Jesús en la Iglesia; Jesús predicaba el Reino de Dios en parábolas, mientras que la Iglesia lo proclama a Él como Señor y Salvador, encerrándolo en formulaciones dogmáticas. $C f$. IZQUIERDo, C., Teología fundamental, EUNSA, Navarra 1998, 519-521; pero sobre todo, para una comprensión de lo que predicó Jesús sobre el Reino con un estudio profundo sobre las diversas etapas del proyecto del Reino mesiánico de Jesús cf. VIDAL, S., Los tres proyectos de Jesús; El proyecto mesiánico de Pablo, Ediciones Sígueme, Salamanca 2005; Jesús el Galileo. Aquí se entenderá cómo la especificidad de Jesús ha quedado olvidada durante 2000 años, soterrada por una teología de corte helenizante que poco tiene que ver con el discurso cristiano; la conclusión es sencilla.... ¿nos podemos confesar cristianos en su especificidad original o somos producto de una tradición deformada? 
bir el evento de la Revelación. La Escritura, sin una encarnación, sin una transmisión quedaría muerta. El problema que aquí brevemente planteo es que la corriente de la Tradición se ha centralizado en una parte del mensaje perteneciente más al anuncio de los testigos primeros y de su desarrollo helenista posterior más que en la especificidad del anuncio de Jesús; este anuncio difiere por completo del nuestro tanto en el modo como en el contenido del mensaje...¿no es una contradicción?

Tras dos mil años de existencia y transmisión, siempre surge el discurso sobre la imposibilidad que durante tanto tiempo la Iglesia se equivoque en el mantenimiento de su vida y mensaje, pero habrá que preguntarse seriamente a la luz de la teología fundamental, basada en una teología de la Revelación bíblica, si se hace justicia al proyecto de Jesús, a su propuesta encarnada o, si por el contrario la Iglesia ha caído en un dinamismo y en un discurso diverso. Desde mi punto mi vista la Iglesia debe recuperar el tono y contenido específicos de Jesús, desde la seriedad y concreción que transparentó en su vida histórica.

En primer lugar, por tanto es el lenguaje que usó Jesús para su anuncio tan distante del dogmático y, en general del cristianismo. Las parábolas suponen un lenguaje abierto, sugerente, desencadenante, intuitivo, que no identifica ni encierra las realidades, sino que las sugiere y las llama a su expansión. Es un lenguaje metafórico que da que pensar..."el Reino de Dios es como"201. La semilla, el grano de mostaza, la levadura...son ejemplos de este misterioso evento que acontece en la vida diaria, y sólo en la cotidianeidad histórica, como algo explosivo 202.

Lo que planteo, por tanto, es que las parábolas no sólo, y como hecho más importante, usan un lenguaje sencillo que reflejan un medio ambiente cultural, sino que, sobre todo reflejan en sí la lógica del Reino, del contenido del mensaje. Así como el modo de la Revelación encarnada, kenó-

201 Cf. WERBICK, J., Essere responsabili..., 487-511; RICOEUR, P., Ermeneutica della testimonianza, en Testimonianza, Parola e Rivelazione, Dehoniane, Roma 1997, 99 (el signo ofrece algo que interpretar); RICOEUR, P., Teoría de la interpretación, Siglo XXI, México 1992, 70; RiCOEUR, P., La metáfora viva, Trotta, Madrid 2001, 150-164 (la metáfora como cambio de sentido).

202 "Gracias al carácter paradójico de las parábolas acaece en el oyente aquello que éstas narran. Es así cómo ayudan a saltar de la óptica y la lógica de la vida banal a una perspectiva divina que nos hace descubrir el potencial inesperado e inaudito que se esconde en cualquier situación humana. Es esa misma situación humana la que precisamente se convierte en parábola, en símil de una gracia y de un salvamento, de una identidad ahora más amplia y profunda. Lo que la parábola hace es transmutar el mundo en símbolo", SALMANN, E., La palabra partida, PPC, Madrid 1999, 59. 
tica nos tiene que decir algo de cómo es el mismo Dios, de la misma manera el modo del anuncio de Jesús, nos indica ya el contenido del mismo anuncio del Reino. Cuando encontramos un talante alegorizante (devoción por otra parte de los Padres de la Iglesia) es ya una evolución postjesuana:

"Las parábolas evangélicas tienen, indudablemente, un amplio e importante núcleo jesuánico: en su gran mayoría, reflejan el medio ambiente histórico, ecológico, social y religioso de la misión de Jesús, y tienen además un tono de inmediatez y viveza, basado en la experiencia inmediata de la vida real, que las marca como algo nuevo frente al material parabólico del judaísmo, centrado fundamentalmente en las comparaciones alegorizantes, en las alegorías y en las fábulas. Pero algunas de las parábolas de Jesús sufrieron una transformación por parte de las comunidades cristianas, al considerarlas como enseñanzas con un sentido oculto que sólo ellas y no los de fuera podían entender, interpretándolas entonces en un sentido alegórico...y acomodándolas a su propia situación y problemática.

El material parabólico fue el lenguaje clave de Jesús en su proclamación del acontecimiento del reino de Dios, porque sólo en ese lenguaje poético de imágenes y comparaciones se podía hablar de ese acontecimiento maravilloso, indefinible por conceptos fijos y categorías. Lo que hacen las parábolas es narrar imaginativamente lo que sucede en ese acontecer sorprendente del reino de Dios. Ésa, y no la enseñanza de verdades generales de tipo religioso o ético, es su clave interpretativa."203

De este modo, la conclusión urgente es necesaria: el lenguaje del cristianismo hoy debería acercarse más al talante de la metáfora, para alejarse del de las predicaciones, catequético, teológico y, por supuesto, dogmático 204 .

Por otra parte, como queda ya aludido, recuperar el mensaje del Reino de Dios es la otra columna necesaria que, desde la teología de la Revelación, se impone para el cristianismo del ya siglo XXI. Una vez sugerida

203 VIDAL, S., Jesús el Galileo, 93.

204 Necesario se hace el lenguaje simbólico como aproximación a lo ausente, como iluminación y como horizonte nuevo que no intenta dominar, ideologizar y conceptuar la realidad, sino narrar algo sobre ella; cf. MARDONES, J.M., Matar, 208-212. 
y anticipada la especificidad de la Revelación, cuya lógica es la kénosis, la pro-existencia, el vivir-para (que nos indica lo constitutivo de Dios y de la persona, así como el desarrollo de su vocación concreta), encontramos una total coincidencia en el contenido de sus parábolas. La centralidad del Buen samaritano, como núcleo del anuncio del Reino, cuyo eje es el amor $^{205}$, nos invita a que la respuesta de cómo amar al prójimo se condensa en la carne, en todo cuerpo porque es trans-significado, trans-metaforizado, trans-figurado. Es en la vida misma, en el acontecer cotidiano corporizado, encarnado donde está presente el proyecto del Reino y la vida de Dios. Ante la pregunta de dónde está mi prójimo, Jesús es claro: en cualquiera que necesite algo para su plenitud, en el imprevisto de lo cotidiano/inmediato que no se deja dogmatizar, moralizar o ritualizar; la presencia de Dios, de su amor se radica en el samaritano como encarnación de Dios-prójimo-próximo operante (extranjero, no perteneciente a los escogidos, no arraigado ni en una nación, ni en una religión, ni en un estado de vida concreto) y en el necesitado como encarnación de Diosprójimo-próximo mendigo de amor.

Si leemos esta parábola a la luz del juicio final de Mateo, concluimos que la presencia del proyecto del Reino, su lógica, la presencia misma de Dios, precisamente se encuentra en su ausencia, en el acontecer normal de la vida. La presencia del Reino está en los sucesos de la vida y sólo así puede surgir lo insólito del Reino y del amor de Dios; la presencialización del Reino, del amor de Dios se juega en la vida encarnada que se ofrece, que vive desde y para la relación. Aquella lógica del universal concreto es precisamente lo que se anuncia en las parábolas: una existencia para (proexistencia), que es donde Dios se hace presente y (des)-aparece. ¿Dónde dice Jesús que se hace presente el Reino o la vida misma de Dios? ¿Dónde se hace presente Dios en el Buen samaritano? ¿Y dónde el juicio final de Mateo?...en la vida-cuerpo de una existencia necesitada de la relacionalidad (kenósis, perijóresis), para su plenitud.

\section{Propuesta litúrgica}

Como última sugerencia, es imposible escapar del cuestionamiento de nuestra ritualidad mágica y exclusiva (entendiendo que configura los límites de la experiencia cristiana). Queda ya dicho: la creación está sos-

205 Por otra parte así es cómo Benedicto XVI, actual Papa, en su encíclica Deus charitas est (2006) argumenta la centralidad del amor en el cristianismo, partiendo, en primer lugar, precisamente de esta parábola. 
tenida por Dios distinguiéndose de ella y Jesús ha introducido una dinámica diversa en la visión de esta relación. Es difícil saber cuál es el momento para rezar o celebrar, cuando entendemos que esto es el límite de la experiencia cristiana, de la manifestación y presencia divina en nuestras vidas 206 .

Cuando la Sacrosanctum concilium habla de la presencia real de Jesucristo en la Eucaristía, sacramentos, Palabra, sacerdote y asamblea reunida está encerrando ritualmente la experiencia de Dios. Ciertamente no excluye otras manifestaciones, pero la teología misma y el Magisterio radicalizan en exceso la experiencia ritual, sacramental, casi hasta la promoción de una religión vacía 207 . No se puede entender la presencia del misterio en

206 Cf. Torres QueIruga, A., Fin del cristianismo, 28-30.

207 Mi crítica a la celebración eucarística como manifestación central de Cristo se basa en la teología bíblica expuesta por Senén Vidal. Una síntesis del proyecto mesiánico de Jesús en los sinópticos y en las cartas de Pablo se puede encontrar respectivamente en sus publicaciones: VIDAL, S., Los tres proyectos de Jesús y el cristianismo naciente. Un ensayo de reconstrucción histórica, Salamanca 2003 y El proyecto mesiánico de Pablo, Salamanca 2005. Para entender la síntesis sobre el sentido de la eucaristía en el proyecto mesiánico de Jesús, que sucintamente expondré a continuación, $c f$. Ibid. 241-257 y 205-215 (respectivamente). Según este autor la última cena estaría inserta en la misma lógica que el resto de los banquetes de la vida de Jesús, con la única diferencia de ligar este último banquete a su muerte salvadora. Entendiendo Jesús que la última etapa del Reino mesiánico por él propuesto llegaba a su fin, usa una vez más el recurso del banquete como acción simbólica de donación, como reflejo de toda una vida empeñada en la lógica de la donación, cuyo máximo exponente es su muerte con un carácter salvador. Esta muerte no se separa del resto de su misión, sino la "extrema concentración de toda su actuación anterior al servicio del reino. Su muerte significa, en efecto, la entrega de toda su vida a favor del pueblo receptor de la liberación del reino (256)". Por tanto, para las primeras comunidades supuso un banquete comunitario con "el soberano mesiánico que había inaugurado ya la época mesiánica con su muerte salvadora y resurrección" (211). Por otra parte, esta celebración "no tenía la intención de convertirse en el inicio de un nuevo rito religioso, sino la de ser un signo efectivo del nuevo camino para la implantación del reino de Dios (209)". Precisamente porque las primeras comunidades se encontraban en una situación diversa a la de la última cena, se sentían ya presentes en la época mesiánica y, por ello, es lógico que retornaran a esta celebración ya que Jesús la vinculó a su muerte salvadora, fundamento del nuevo pueblo mesiánico.

Llegados a este punto me parece necesario recordar con las palabras del autor que así fue el sentido querido por Jesús en la última cena, pero como "acción simbólica" (210). Es decir que Jesús vinculara este banquete con gestos de donación a su muerte salvadora mediante tal acción simbólica, no implica tanto su presencia (más perteneciente a ritos sacrificiales paganos) durante su celebración, cuanto un medio de cohesión de la comunidad mesiánica que celebra la lógica de vida de su soberano mesiánico. Pero me parece más adecuado en insistir en una presencia más cualitativa de Jesús en su Iglesia a través de la lógica de su vida, de la donación, del hacerse presente en la responsabilidad por el otro en una "ausencia" de Dios. 
los sacramentos, sino se parte de la experiencia de la vida, de la existencia concreta, de la anulación de los espacios sagrados y profanos 208 . Nuestra eucaristía, a veces no está muy lejos de los sacrificios paganos, donde se pone algo ajeno sobre el altar para conseguir el favor de Dios ${ }^{209}$.

Por el contrario, la lógica de nuestra eucaristía y de nuestra sacramentalidad necesita despojarse de cubiertas sacrales y dejarse penetrar de una celebración existencial, donde la implicación de la persona es fundamental$^{210}$. Entender por ejemplo que la última cena fue una celebración del don de sí mismo, de la más alta oferta de la corresponsabilidad histórica, nos ayuda a entender la conexión entre la vida (en-carn-ada) y la liturgia 211 . No hay saltos ni espacios diversos; la vida está toda atravesada por Dios y, en la liturgia, simplemente celebramos la consecuencia de nuestro modo de ser especialmente históricos. El ofertorio de cada eucaristía debería ser el momento en que deberíamos repetir el "haced esto en conmemoración mía", es decir, repetir la intención de Jesús en la última cena, uniendo nuestra vida como oferta del don de sí mismo al prójimo, al hermano, siempre desde la perspectiva que he intentado desarrollar.

Entender el resto de sacramentos dentro de esta lógica del don de la persona, de la oblación existencial es coincidir con nuestra reflexión teológica sobre la consecuencia de una religión secularizada y secularizante: vivir en la lógica de la corresponsabilidad, del don, del ser hijos, del cuidar al hermano, de la libertad y de la identidad como cocreadores. El matrimonio, el sacerdocio, la confirmación son distintos matices de la lógica del don de sí mismo, que escapa de concepciones excesivamente sacrales sobre la intervención divina ${ }^{212}$.

\footnotetext{
208 Recordamos que la narración bíblica y el proyecto de Jesús son, precisamente, desacralizantes, secularizadores, es decir, que anula la diferencia sacro-profano, revelando que la única dimensión de la persona es la historia, vía de plenitud y salvación.

209 Cf. SC 7.

${ }^{210}$ También esto exigiría, por otra parte, la re-creación y puesta en práctica de mil formas "de comunidad de mesa, para compartir la necesidad humana (simbolizada en el pan) y comunicar la alegría y esperanza (simbolizadas en el vino), en ese gesto a la vez tan humano y tan presencializador de Cristo": GonZÁLEZ FAUS, J.I., Calidad, 290.

211 Falta toda una reflexión, a partir de Salmann, Esperienza mistica e pensiero filosofico, "I sensi del senso, il senso dei sensi", de la liturgia como máximo sacrificio del inmediato. Grillo, Liturgia e teologia fondamentale. Il rapporto tra immediatezza e mediazione nella riflessione teologica. La liturgia es una simbolización de $2^{\circ}$ grado, que intenta compensar la imposibilidad de la plenitud en las relaciones inmediatas-carnales de comunicación (símbolo de $1^{\circ}$ grado).

212 Torres QueIRUga, A., Fin del cristianismo, 81: “ Porque, con independencia de nuestras intenciones expresas, pedirle algo a Dios equivale a invertir todo el movimiento, situando la iniciativa del lado humano, y la pasividad del lado divino"; cf. ibid. 30-32.
} 


\section{Conclusión}

Después de mi exposición sólo me queda intentar condensar el núcleo de mi tesis. La fragmentación, desencanto y deshumanización que nos porta la religiosidad pagano-nihilista, no nos tiene que hacer olvidar su lectura positiva de la vida y sus propuestas concretas a favor de la existencia. Por otro lado, no se puede negar el gran influjo que hoy este fenómeno causa dentro del cristianismo, conllevando una crisis de identidad y una falta de perspectivas.

Dentro de esta confusión, el cristianismo sólo puede resurgir desde la experiencia más profunda de la Revelación, atreviéndose a asimilar su identidad más original: la vivencia de una religiosidad secular y hermenéutica, que se desarrolla históricamente en la creaturalidad y cocreación (libertad responsable y creativa) por la irrechazable condición de hijos que la Revelación de Jesucristo nos ha mostrado a partir de su singular interpretación de la relación existencial existente entre Dios-hombremundo-historia, nacida de su comprensión de Dios como Abbá-Padre ${ }^{213}$.

En este sentido se puede re-proponer a Jesús como alternativa vigente de frente a los desafíos de la religiosidad nihilista-neopagana. Ante el decremento existencial que apuesta por una "salvación mágica y automática" o por un mero confort personal, Jesús en su proyecto vital nos ofrece una dimensión salvífica, plenificadora de las necesidades de la persona concreta. Delante a los fenómenos de la eclosión de la vida y del hedonismo a ultranza, Jesús se presenta como una propuesta no simpática, sino revolucionadora, molesta, diversa a la religiosidad que justifica los intervencionismos divinos en la vida cotidiana, permitiendo legitimar así la realidad.

En definitiva, se trata de un replanteamiento de la experiencia trinitaria, re-partiendo desde esta singular interpretación de Jesús 214 . Efectivamente una Trinidad entendida desde la manifestación en Jesús nos lleva a entender que las misiones nos deben decir algo de la vida trinitaria y, por ello sobre la vocación del hombre ${ }^{215}$. Por esto la Revelación cristiana es una propuesta de sentido y, por ello, creíble 216 , porque la lógica del Amor transforma las relaciones entre Dios y el mundo, entre lo humano y lo divino,

213 PANIKKaR, R., La pienezza, 123-141; KASPER, w., Il Dio, 230-238.

214 Para una pequeña síntesis de lo que significa partir desde abajo para llegar a la luz de la Revelación cf. MARDONES, J.M., Fin del cristianismo, 51-54.

215 Sobre la correspondencia entre las misiones y procesiones, Trinidad económica e inmanente, donde las misiones no fundan las procesiones, pero manifiestan la vida divina cf. LADARIA, L.F., La Trinitá, 49-66.

216 PIÉ-NINOT, S., La teología fundamental, 221-238. 
porque, detrás de toda esta teología secular-hermenéutica se encierra la conciencia de que sólo el amor es digno de fe $\mathrm{f}^{217}$.

\section{Pablo Tirado Marro, OSA}

${ }^{217}$ He querido finalizar con el título de la obra de Balthasar, para resaltar la esencia de esta reflexión como teología fundamental. La profundización de estos aspectos cristológicos han querido ser, antes que nada, una posible apertura a la credibilidad de la Revelación-fe cristianas. 